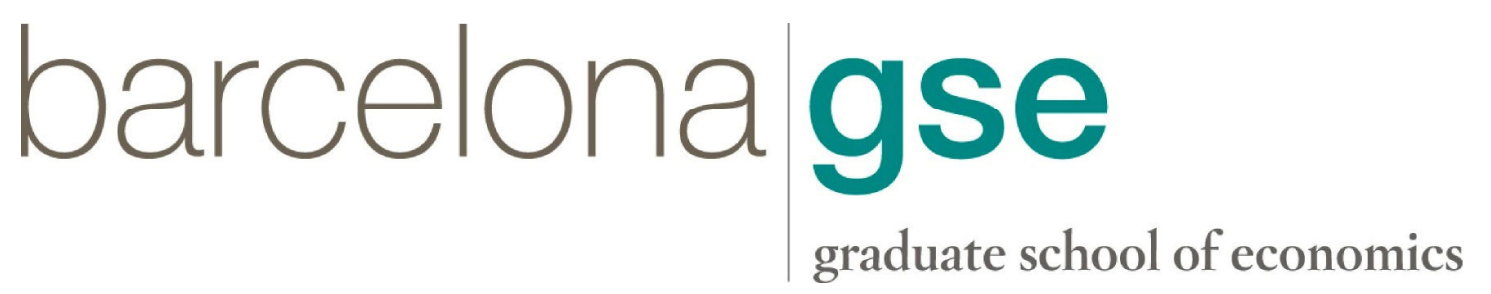

\title{
Immigrants' Assimilation Process In A Segmented Labor Market
}

\author{
Miguel Angel Alcobendas \\ Núria Rodríquez-Planas
}

March 2010

Barcelona Economics Working Paper Series

Working Paper $n^{\circ} 442$ 
IMMIGRANTS’ ASSIMILATION PROCESS

IN A SEGMENTED LABOR MARKET

\author{
Miguel Angel Alcobendas \\ Universitat Autònoma de Barcelona, and Inside-Spain \\ Núria Rodríguez-Planas \\ Universitat Autònoma de Barcelona, \\ IZA, MOVE, CREMed, FEDEA, and Inside-Spain
}

First version: September 2009

This version: March 2010

\begin{abstract}
While much of the literature on immigrants' assimilation has focused on countries with a large tradition of receiving immigrants and with flexible labor markets, very little is known on how immigrants adjust to other types of host economies. With its severe dual labor market, and an unprecedented immigration boom, Spain presents a quite unique experience to analyze immigrations' assimilation process. Using data from the 2000 to 2008 Labor Force Survey, we find that immigrants are more occupationally mobile than natives, and that much of this greater flexibility is explained by immigrants' assimilation process soon after arrival. However, we find little evidence of convergence, especially among women and high skilled immigrants. This suggests that instead of integrating, immigrants occupationally segregate, providing evidence consistent with both imperfect substitutability and immigrants' human capital being under-valued. Additional evidence on the assimilation of earnings and the incidence of permanent employment by different skill levels also supports the hypothesis of segmented labor markets.
\end{abstract}

Key words: immigrants' assimilation effects, cohort effects, and occupational distributions and mobility, segmented labor markets.

JEL classification: J15, J24, J61, J62

Financial support from the Spanish ministry of Education and Science (grant SEJ2006-712) and the Generalitat de Catalunya (grant SGR2005-712) is also gratefully acknowledged. The authors are grateful to Sara de la Rica, Albrecht Glitz, and Jesus Fernández-Huertas for extremely useful comments that have helped improve the paper substantially. They also thank Lacuesta and Vegas for providing estimations from the Continuous Sample of Working Histories. Finally, the authors appreciate the thorough comments from participants of ESPE 2009 conference, the $3^{\text {rd }}$ INSIDE 
Workshop, and the 2009 Immigration IZA Workshop. 


\section{Introduction}

Much of the literature on immigrants' assimilation has focused on countries with a long tradition of receiving immigrants. ${ }^{1}$ In addition, despite the well known institutional and labor market differences existing across these countries, these economies represent relatively flexible labor markets, in sharp contrast with the segmented labor markets found in southern European countries, transition economies or developing countries. ${ }^{2}$ Most of these studies find that after an initial adaptation period, immigrants' earnings converge towards those of natives. What is still an open debate in this literature is whether and to what extent full-convergence takes place. ${ }^{3}$

In contrast, not much is known on how immigrants adjust to an economy with little experience as a host country and in which its labor market presents a strong dualism. Understanding immigrants' assimilation process in such circumstances can be of most policy relevance, especially in the midst of the new immigration flows towards the fast growing developing economies, which tend to have heavily segmented labor markets. ${ }^{4}$ As Hatton and Williamson, 2005, highlight changes in the direction of world-

\footnotetext{
${ }^{1}$ Countries with a long tradition of receiving immigrants include: Australia (Chiswick and Miller, 1995); Canada (Baker and Benjamin, 1994; and Hum and Simpson, 2000, 2004); Germany (Pischke, 1993; Schmidt, 1992; and Constant and Massey, 2005); Israel (Sabatallo, 1979; Flug, Kasir and Ofer, 1992; Friedberg, 2001; and Eckstein and Weiss, 2004, among others); and the United States (Chiswick, 1978; Borjas, 1985; Friedberg, 1993; LaLonde and Topel, 1992; Borjas, 1995;; Hu, 2000; Lubotsky, 2000; Duleep and Dowhan, 2002; Duleep and Regets, 2002; Card, 2005; and Blau and Kahn, 2007; among others).

${ }^{2}$ Clearly the segmentation of the labor markets differs drastically between southern European countries and developing countries. For instance, in the case of Spain the segmentation is due to the fact between one fourth and one third of the labor force works with temporary contracts, which imply high job turnover, and little training and benefits. In contrast, in developing and transition economies the segmentation is caused by a significant fraction of the labor force being unable to find wage and salary jobs with benefits in high productivity sectors and, therefore, being pushed out of the labor force and into low productivity jobs, primarily in subsistence agriculture, the urban underground economy, and the unregulated self-employed sector. Nonetheless, and despite the differences, there are striking similarities, namely the fact that a many workers are "outsiders" working in precarious jobs, while others are "insiders" working in overly protected good jobs.

${ }^{3}$ See Card, 2005, or Fernandez and Ortega, 2008, for a thorough discussion on these issues.

${ }^{4}$ Recent evidence indicates that South-South migration accounts for half of all migration from the South: According to Ratha and Shaw, 2007, "some of the largest migration corridors are in the South. After the Mexico-United States corridor, the next three largest are estimated to be Russia-Ukraine, UkraineRussia, and Bangladesh-India. Many of these large migration corridors emerged due to the partitioning of countries. When such corridors are excluded, the largest of the remaining corridors are not all South-
} 
migration trends towards a more South-South direction are likely to create new problems for newly industrial economies. Unfortunately, lack of good data in developing countries makes this analysis difficult to undertake. ${ }^{5}$

In this paper, we propose to use Spain as a quite unique experience to analyze such issues as the country experienced an unprecedented immigration boom in a short period of time-with immigrants representing from 1\% of the population in 1990 to $12 \%$ in 2009 - ${ }^{6}$ and presents an extreme case of labor market dualism-with at least one third of its labor force in the secondary labor market for the last two decades. ${ }^{7}$ While it is true that, currently, the Spanish economy differs in many ways from a developing economy; its social, political and economic situation three decades ago was not that different from the present situation of many Eastern European countries or other developing countries, implying that much can be learned in the developing world from the Spanish experience. In addition, in spite of its spectacular changes, Spain still suffers from serious problems similar to those experienced by emerging countries, such as, a low productivity growth, excessive borrowing, strong rigidities in its labor market and its financial and banking systems (Andrés, 2009; Garicano, 2008; de la Rica, 2009; Estrada et al., 2009; and Cuñat and Garicano, 2009).

The contribution of this paper is to provide new evidence on how immigrants adjust to a host country with strongly segmented labor markets. More specifically, we use data on the recent immigration wave in Spain to compare the occupational

\footnotetext{
North-some are North-North, others South-South. India, Russia, and South Africa are well-known as receiving countries in the South."

${ }^{5}$ To our knowledge Gindling, 2009, is the first one to analyze the impact of immigrants from one developing country (Nicaragua) to another one (Costa Rica). In addition, several studies have studied rural-urban migration in urban China where segmented labor markets are a key element of the urban labor market (Wu and Li, 1996; Xiang, 1996; Knight et al., 1999; Meng, 2000; and Meng and Zhang, 2001). Finally, there is some research on the impact of emigration from a developing country on the labor market of the migrant sending country (for example, Aydemir and Borjas, 2007 and Hanson, 2008).

${ }^{6}$ Since early 2000s, the average annual flow of immigrants in Spain has been around 500,000 per year.

${ }^{7}$ With the current crisis, the proportion of workers with fixed-term contracts has gone down to $25 \%$ for the first time since 1989.
} 
distribution of immigrants to that of native-born Spaniards, and in particular with native-born Spaniards with similar observable characteristics. In addition, we examine how the occupational distribution of immigrants has changed with time spent in Spain. All along, we pay special attention on possible heterogeneity effects, that is, we explore whether and to what extent the assimilation process of immigrants varies by gender, education level, or continent of origin. The paper provides new evidence on the extent the immigrant resource is underutilized in Spain, and improves our understanding of the recent wave of immigrants' adaptation process. In particular, the evidence seems to support the segmented labor market hypothesis. The paper discusses policy implications for countries with severe segmented labor markets.

While much of the literature on immigrants' assimilation focuses on earnings assimilation, such an approach offers a limited and one-dimensional view of the adaptation process of the newly arrived, or as Card, 2005, puts it: “On the question of immigrant assimilation, ... a narrow focus on immigrant earnings is misplaced". A richer and alternative measure of assimilation that conveys both labor market adaptation and socioeconomic status attainment is provided by observing the occupational distribution of immigrants relative to that of natives as time in the host country increases. In addition, as Green, 1999, explains: "Information on the occupational distribution of immigrants and how it changes with time in a host economy is central to understanding how immigrants affect economic growth and how they adjust to a host country both in economic and social terms.”

To conduct our analysis, we estimate separate multinomial logit models of occupational choice for immigrants and native-born individuals using cross-sectional data from the 2000 to 2008 Spanish Labor Force Survey. Our model of occupational selection relates selection to observable characteristics such as age, sex, education level, 
and place of residence. In addition, for immigrants the occupational choice is related to region of birth as well as to years since arrival in Spain. We follow the synthetic cohort analysis proposed by Borjas, 1985, and 1995, in the immigrant earnings literature and track specific immigrant waves across a succession of cross-sections. In this manner, we are able to disentangle the cohort effect from the assimilation effect. ${ }^{8}$

Our analysis highlights three important results. First, we find that immigrants are more occupationally mobile than natives. Most of this greater flexibility is explained by immigrants' assimilation process soon after arrival to the host country: Just after arrival, immigrants enter occupations below their skill level and then move towards higher skilled occupations. However, our second finding indicates that convergence does not occur: Immigrants are not valued the same way as comparable natives, even after assimilation to the new labor market, language and country has taken place, as they segregate into low-skilled occupations (compared to natives with similar observable characteristics) — this reflects a low degree of transferability of their imported observable skills, and/or labor discrimination. Third, we find that, among male immigrants, the degree of assimilation is higher the lower their education level. We interpret this last result as evidence of segmented labor markets and provide additional robustness tests looking at the assimilation in terms of earnings and incidence of permanent employment by different skill levels that support this hypothesis

This paper is more closely related to the work of Amuedo-Dorantes and De la Rica, 2007, as they also study the occupational assimilation process of the immigrants in Spain. Using 2001 decennial Population Census data, the authors find evidence of immigrants’ progressive employment and occupational mobility as their residence in Spain increases. Unfortunately, due to data limitations, their analysis focuses on

\footnotetext{
${ }^{8}$ Green, 1999, has applied this framework to analyze immigrants’ occupational mobility relative to natives.
} 
immigrants who arrived during the second half of the 1990s and, therefore, misses most of the massive recent inflow of immigrants. Moreover, given that they only have a single cross-section, they are unable to follow the synthetic cohort analysis proposed by Borjas and used in this paper. ${ }^{9}$

When expanding the analysis to the beginning of the $21^{\text {st }}$ century, several authors have analyzed immigrants' assimilation in Spain by looking at wages or immigrant's labor market success. For instance, using cross-sectional data from the 1996 to 2005 Spanish Labor Force Survey, Fernandez and Ortega, 2008, find that although the Spanish labor market is able to absorb immigrants within five years after arrival, it does so at the expense of allocating them in temporary jobs for which they are overqualified. $^{10}$ Similarly, using recently available panel data from social security records, Izquierdo et al., 2009, find that, despite a sizeable and significant wage gap reduction between immigrants and natives within the first five years after arrival to Spain, full assimilation of wages does not take place as a 15 percentage points wage differential remains. While the above two studies analyze the differential effect by continent of origin, none focus on differences across immigrants' education level. Our study is the first to do so, and to find a differential assimilation pattern for low- versus high-skilled immigrants enabling us to disentangle some of the mechanisms behind assimilation.

The structure of our paper is as follows. Section 2 presents the motivation and several theoretical considerations. Section 3 discusses the Spanish institutional background, the data, and descriptive statistics. Section 4 contains the main results.

\footnotetext{
${ }^{9}$ Amuedo-Dorantes and de la Rica, 2007, restrict their analysis to immigrants who arrived between 1996 and 2000, and assume that the quality of immigrant cohorts over this 5-year period has remained unchanged.

${ }^{10}$ Fernandez and Ortega, 2008, use the following four measures of immigrants' success in the Spanish labor market: (1) the labor force participation rate, (2) the unemployment rate, (3) a statistical measure of over-education that considers that a worker is overeducated when his/her level of education is above the mean plus one standard deviation of their occupational category, and (4) the incidence of temporary contracts.
} 
Section 5 discusses alternative channels through which assimilation may take place. The paper concludes, in Section 6, with a discussion on alternative theoretical explanations for our findings.

\section{Relevance of Understanding Immigrant’s Occupational Distribution}

To understand immigrants' contribution to a host country, it is key to analyze immigrants' education or skill composition at arrival relative to that of the receiving economy, and how this immigrants' skill composition varies to that of natives over time. As Dustmann et al.'s 2005 discussion of the underlying theoretical analysis of the labor market effects of immigration emphasizes, only if immigrants' inflows change the skill composition of the native labor force, disequilibrium between supply of and demand for different types of labor at existing wages and output levels will occur and lead to short-run changes on wages and employment of natives as the economy moves to a new equilibrium. The authors highlight that whether the economic theory predicts long-run effects depends on the assumptions being made on the flexibility of the output mix or the closedness to international trade.

Clearly, immigrants can change the skill composition of the host country's resident labor force through three different mechanisms: (1) by having different skills from those of natives at arrival, (2) by how they assimilate to the host country during the first years after arrival, and (3) by whether they adapt differently to the economy than natives. For instance, even in the hypothetical case in which immigrants had the same skills as natives at arrival to the host country, their lack of knowledge on how to find job offers (Chiswick, 1986; Manning, 2003; and Frijters et al., 2005) or the difficulties in getting their credentials recognized (Green, 1995) could well generate a transitory disequilibrium in which recently arrived highly qualified immigrants would compete for 
low-skill jobs while building up knowledge of the host country’s labor market, so that, with time, they could find jobs that matched their skills. This is the well known assimilation process most immigrants initially go through when they first arrive to a country, and in and by itself such process can generate short-run disequilibrium in certain types of labor markets. Alternatively, even after immigrants have assimilated, they may well react differently from natives to economic changes. This may occur because immigrants may be less geographically attached than the native labor force, have different taste or preferences towards work or different types of work, or may care less (or differently) about socio-economic status of certain jobs or occupations.

It is well known that the country's immigration policy plays a key role in determining the occupational distribution of immigrants at arrival—see Cobb-Clark, 2000, 2003; Richardson et al., 2001, 2002; Chiswick and Miller, 2006; and Thapa and Gørgens, 2006, for evidence from Australia; Green, 1999, for evidence on Canada; Bell, 1997, for evidence on the UK; Chiswick, 1978; Borjas, 1992; Card et al., 2000; and Card, 2005, for evidence on the US; or Duvander, 2001, for evidence on Sweden. Regardless of their initial ethnic-mix and occupational distribution, the evidence shows that immigrants go through a similar assimilation pattern in the first couple of years after arrival in which they initially face a period of non-employment or employment in low skill jobs as they learn how the host country’s labor market works. As immigrants spend time in the host country and gradually acquire this country-specific knowledge, their labor market performance may improve relative to that of their native counterparts (for Canada, see Richmon and Kalback, 1980; Boyd, 1985; Green, 1999; for Israel, see Flug et al., 1992; Cohen and Eckstein, 2002; for Spain, Izquierdo et al., 2009; and for the United States, see Chiswick 1978b; Jasso and Rosenzweig, 1988, Borjas, 1992). However, full convergence of immigrants' occupational distribution towards that of 
natives may not necessarily occur. First, if the country's immigration policy has imposed restrictions on immigrants' entry that match immigrants' skills to host country labor demand needs, new immigrants will have an occupational distribution that reflects the highest demand growth sectors more than will the distribution of the native born. Second, although some convergence may occur over time, complete assimilation is unlikely to take place if native-born new labor market entrants move towards sectors less saturated by immigrants. In addition, once assimilation of immigrants has taken place, it is likely that immigrants end up being more occupationally mobile than natives and that they adapt differently to economic shocks than natives (as found by Green, 1991; Barth et al., 2004 and 2006; Dustmann et al., 2009; Fernandez and Ortega, 2008; and Izquierdo et al., 2009).

\section{Institutional Background and Data}

\section{III.1. Segmented Labor Market and Immigration Policy in Spain}

\section{Segmented Labor Markets}

Most of the existing literature on the assimilation of immigrants uses data from Australia, Canada, Germany, Israel, the UK or the US where the incidence of temporary or fixed-term employment is relatively low. Table 1 shows statistics for some of these countries and illustrates that Spain is among the countries with the highest (by far) incidence of fixed-term employment (OECD, 2008). These figures highlight that the assimilation process of immigrants in Spain may differ given the unique specificities of its labor market. Below, we provide some institutional background on how temporary contracts emerged in Spain and discuss some evidence that indeed fixed-term contracts are in the secondary labor market. 
In mid-1970s Spain had very high firing costs inherited from the Franco regime. To reduce them, fixed-term labor contracts were introduced in 1984, with the objective of adding flexibility and promoting employment in a rigid labor market with stringent employment protection legislation and high levels of unemployment. The policy backfired, and fixed-term employment soared, promptly reaching one third of the Spanish labor force, and creating a dual labor market with workers with fixed-term contracts holding unstable, low protected and poorly paid jobs, while workers with indefinite contracts enjoyed protection and presumably also higher wages-Segura et al., 1991; Bentolila and Dolado, 1994; Jimeno and Toharia, 1993, Hernanz, 2002; de la Rica, 2004; and Estrada et al., 2009. The reforms of 1994 and 1997 aimed to enhance the use of permanent contracts and reduce its cost. However, both reforms were quite unsuccessful at reducing the share of temporary contracts in the labor force-see Kugler et al., 2005, and Dolado et al., 2002.

Many authors have provided evidence that fixed-term contracts in Spain are in the secondary labor market (Güell and Petrongolo, 2007; García-Ferreira and Villanueva, 2007; and Barceló and Villanueva, 2010, among others). For instance, Güell and Petrongolo, 2007, find that the conversion rate of fixed-term contracts into permanent ones has decreased over time, as it has gone down from 18\% in 1987 to $5 \%$ in 1996, reflecting the fact that employers use fixed-term contracts more as a flexible device to adjust employment in the face of adverse shocks than as stepping stones towards permanent jobs. Similarly, Amuedo-Dorantes, 2000, finds that temporary work spells in Spain are unlikely to end in permanent jobs, regardless of workers' tenure, and that temporary work is more likely to become a trap than a bridge to permanent employment. Another piece of evidence suggesting that fixed-term contract labor market is a secondary labor market in Spain is provided by Dolado et al., 1999, 
who estimate that the probability of receiving free or subsided on-the-job training was $22 \%$ lower for workers under fixed-term contracts than for workers under permanent contracts, and by Jimeno and Toharia, 1996, who also suggest that temporary employment increases work accidents, which happen to be three times larger for workers under fixed-term contracts than for workers under permanent contracts. Finally, Amuedo-Dorantes, 2000, also provides evidence that temporary contracts are less desirable then permanent ones in Spain. This author estimates that $85 \%$ of temporary workers in Spain in 1996 are involuntarily holding a temporary job because of their inability to find a permanent job. In addition, she finds that only $0.4 \%$ of temporary workers claim that they have been seeking a temporary job.

\section{Spanish Immigration Policy}

Although Spain has traditionally been a country of emigrants, in the last decade the immigrant population in Spain has soared. While, as recently as a decade ago, immigrants made up less than $2 \%$ of the population, they are now over $12 \%$. Most of this massive inflow of immigrants has taken place after the turn of the new century. Several factors explain this rapid change. First, Spanish booming economy and the social promotion - in the form of increased education levels and higher labor force participation —of its national (especially female) population generated a demand for foreign workers (Carrasco et al., 2008 a; Domingo et al., 2006; and Gil and Domingo, 2007). ${ }^{11}$ Second, its physical proximity to northern Africa and Eastern Europe places Spain close to countries that supply immigrants. ${ }^{12}$ Third, its shared language and historical pass with Latin Americans facilitates the social and cultural assimilation of immigrants from this continent, as illustrated by the fact that close to $50 \%$ of the immigrants are from Latin America. Finally, the progressive culture of post-Franco

\footnotetext{
${ }^{11}$ In contrast with northern European countries, the ageing of national working-age population does not explain the arrival of large number of immigrants in Spain (Domingo et al., 2006).

${ }^{12} 17 \%$ and $34 \%$ of the immigrants in Spain come from Africa and Europe, respectively.
} 
Spain has also contributed to increase immigrants’ social acceptance (New York Times, 2008).

Spain has not had an active policy of attracting immigrants. As early as 1985, Spain imposed severe restrictions on non-European Union foreigners who wanted to establish Spanish residency and citizenship. ${ }^{13}$ Beginning 1993, further tightening took place with tougher restrictions on work and residency permit renewals and the implementation of immigration quotas system, which limited the entry of foreigners to about 30,000 immigrants per year. At the turn of the century, Spain updated its immigration legislation and assimilated it to that of other European countries.

However, the free-entrance of foreigners as tourists together with a lax implementation of immigration laws and several generous amnesties that have granted legal residence to illegal immigrants (1985, 1991, 1996, 2000, 2001, and 2005) have de facto converted Spain in an immigrant friendly country (Dolado and Vázquez, 2007; Izquierdo et al., 2009, among others). In fact, the most common way of obtaining legal status in Spain during the past two decades has been through amnesties. Most frequently immigrants arrived in Spain either illegally or as tourists, and they were subsequently granted legal status through the multiple amnesties that have been granted since the mid-1980s_-see Amuedo-Dorantes and de la Rica, 2005, 2008, Dolado and Vazquez, 2007, and Izquierdo et al., 2009. ${ }^{14}$ Between 1985 and 1991, as many as 150,000 immigrants regularized their status; between 1996 and 2001, a total of 400,000 immigrants did the same; and in the last amnesty, that of 2005 , as many as 550,000 immigrants got their residence permits.

\footnotetext{
${ }^{13}$ To have the legal status, immigrants were required to acquire a work and residency permit that restricted them to work in a particular activity and geographic area only for a year. In addition, immigrants were not granted any social benefit despite paying social security taxes when employed.

${ }^{14}$ For instance in the 2000 amnesty to become legal aliens, immigrants had to provide proof of one of the following: (i) residence since June $1^{\text {st }}$, 1999; (ii) having held a work permit any time during the three-year period preceding February $1^{\text {st }}$, 2000; (iii) being denied asylum before February 2000; (iv) having applied for any type of residence permit before March $30^{\text {th }}$, 2000; or (v) family ties to legal residents or to individuals in any of the previous categories.
} 


\section{III.2. Data and Descriptive Statistics}

Our analysis is mainly based on data from second quarter of the Spanish Labor Force Survey (LFS) from the years 2000 to $2008 .^{15}$ The Spanish LFS gathers information on demographic characteristics (such as, age, years of education, marital status, and region of residence), and employment characteristics (such as work status, occupation, and industry). ${ }^{16}$ In addition, for immigrants-defined as foreign-born workers who do not have the Spanish nationality, the LFS collects information on the number of years of residence in Spain and the country of birth.

The native-born samples are random samples of males and females aged 20 to 64 at the time of the relevant LFS. The immigrant sample consists of all immigrants in the relevant LFS who entered Spain after January 1, 1990, were aged 20 to 64 at their time of arrival, and are under age 65 at the time of the relevant LFS. Analysis is restricted to immigrants aged 20 to 64 at time of arrival to concentrate on individuals who were likely headed for the labor force in the near future and to avoid issues of noncomparability of the experiences of young immigrants who received part of their basic education in Spain and those who arrived at older ages. ${ }^{17}$ The samples are restricted to individuals under age 65 in the LFS year to avoid complications involving retirement decisions. The immigrant samples are restricted to those entering in 1990 and after because the vast majority of immigrant flows has taken place from the late mid-nineties onwards. $^{18}$

\footnotetext{
${ }^{15}$ As is common practice in the research using this dataset, we only use the second quarter to avoid repeated observations. The LFS is carried out every quarter on a sample of around 60,000 households. Each quarter, one sixth of the sample is renewed. However, the dataset does not include a variable that allows identification of individuals along the six consecutive interviews.

${ }^{16}$ Unfortunately, no earnings data is available in the Spanish Labor Force Survey. In Section V of this paper, we shall use an alternative data sets, to estimate earnings assimilation by skill level.

${ }^{17}$ This restriction criteria is common in the literature, see Boyd, 1985; Kossoudji, 1989; and Green, 1999, among others.

${ }^{18}$ Again this is a common restriction in the Spanish literature, see Amuedo-Dorantes and de la Rica, 2007, and Gonzalez and Ortega, 2008, among others.
} 
One of the strength of the LFS is that it is supposed to include both legal and illegal immigrants, in contrast with alternative datasets that only cover legal ones, such as the data from data from Social Security Records (Ramos-Muñoz, 2007) or the Wage Survey Structure (Carrasco et al, 2008a). That said, the potential under-reporting of illegal immigrants is likely (as the LFS is voluntary, in contrast with the Census, which is mandatory) especially before an amnesty. Similarly, return migration related (or not) to an amnesty may also be worrisome, as both return migration and under-reporting of immigrants may generate deterministic biases in our analysis. Appendix Table A.1. shows the population sizes for the different entry cohorts of immigrants at each LFS. While there is some variation in sizes across LFS, no clear pattern is observed that would raise major concerns of return migration (as there are not regular patterns for decreases in cohort sizes). In contrast, while one can observe sizeable increases in population sizes for the 2000 and 2005 entry cohorts the year after the 2001 and 2005 amnesties, there are similar increases observed for the 2001 cohort in 2003, the 2002 cohort in 2004, or the 2006 and 2007 cohorts in 2007 and 2008, respectively, (when no amnesties took place) suggesting that under-reporting of legal and illegal immigrants is observed during the first couple of years after arrival. ${ }^{19}$ Nonetheless, for this to be a problem, it needs to generate a deterministic bias in our analysis. ${ }^{20}$ Table A.2 shows the

\footnotetext{
${ }^{19}$ Given that the LFS is a household survey (as opposed to an individual survey), it only includes individuals living in registered households, which may lead to some under-reporting of recently arrived immigrants (legal or not), probably due to the fact that as they have just recently arrived and have not yet permanently settled in a household, they might still be considered as "guests" from the survey respondent's view (Fernandez and Ortega, 2008, also acknowledge this data problem).

${ }^{20}$ The direction of the bias caused by under-reporting of immigrants the first couple of years after arrival in unclear. On the one hand, one may suspect that among those under-reported there are more illegal aliens, which could well be in a more vulnerable and disadvantaged position than the legal ones. On the other hand, it may well be that those illegal aliens who decide to stay in Spain end up being those more capable of overcoming hardships, and therefore, on average, more talented individuals. Similarly, the direction of the biases caused by return migration is not always obvious, as explained in AmuedoDorantes and de la Rica, 2007: "On the one hand, it is possible that migrants who experience hardships upon arrival to the host country are the ones returning home. Alternatively, it may be the case that these migrants are the ones encountering a greater difficulty to return to their distant countries. As such, they are the ones to stay longer relative to more successful migrant who may choose to go back to their countries after successfully working and saving enough money in the host country.”
} 
demographic characteristics of the 2002 cohort of immigrants at each of the different LFS. $^{21}$ While small changes are observed across surveys, in essence the sociodemographic characteristics of the cohort remains quite stable across surveys, implying that no deterministic bias would emerge in our analysis. ${ }^{22}$ Finally, the fact that we pool LFS years from 2000 to 2008 minimizes the potential biases that may rise from the successive amnesties because most undocumented immigrants in our sample with at least one year of residence are likely to have been legalized. Therefore, although amnesties may affect in some ways the estimates of the year prior to the amnesty for the recently arrived immigrants, subsequently these individuals have no reason to misreport their date of arrival once they are legal aliens. For all these reasons, and given that we focus on year-to-year differences in assimilation rates, we do not think that amnesties ought to be a major concern in our analysis-similar argument was presented in Amuedo-Dorantes and de la Rica, 2007.

Table 2 displays personal and demographic descriptive statistics for natives and immigrants for each of the LFS years (descriptive statistics by gender, continent of origin, and cohort of arrival can be found in Tables A.3 and A.4 in the Appendix). The major difference between the two population groups is that immigrants are younger than natives. ${ }^{23}$ In addition, we observe that there are education differences across the two groups. ${ }^{24}$ Within the native population, there has clearly been an increase of workers' investment in human capital, as the fraction of natives with a college degree, vocational training, or a high-school diploma has increased over the nine years under analysis.

\footnotetext{
${ }^{21}$ Similar results are found for other cohorts (available from the authors upon request).

${ }^{22}$ This result is consistent with findings of Fernández and Ortega, 2008, which use the same dataset to analyze the assimilation of immigrants in terms of labor force participation, and temporality.

${ }^{23}$ One exception is in the range between 20 and 24 years old, where we observe that there are more natives than immigrants. This is an artifact of how the sample of immigrants was selected as we restricted immigrants to be 20 years old or older at the time of arrival.

${ }^{24}$ Throughout the analysis we consider four education levels: high-school dropouts; individuals with a high-school degree; individuals with some college education or vocational training (they may have a trade certificate, but no college degree); and individuals with completed university studies.
} 
Although a similar trend is observed for immigrants with less than a college degree (with the share of those with vocational training increasing the most), the share of immigrants with a college degree has decreased over-time from $22 \%$ to $17 \%$. Comparing immigrants and natives in our sample, we observe that immigrants are slightly more educated than natives (especially in the earlier surveys). ${ }^{25}$ Finally, it is noteworthy to highlight the change in the continent of origin of immigrants over the last decade. While in the early 2000s, immigrants came from the EU15, Africa and Latin America in similar proportions; by the 2008 LFS, the weight of immigrants from EU15 and Africa has been reduced drastically, representing only $10 \%$ and $17 \%$, respectively, and giving room to a large inflow of immigrants from Latin America (44\%) and Eastern Europeans (24\%).

Table 3 presents the occupational distributions at each LFS for the native born and for immigrants from each of the entering cohorts. The occupations are grouped into five categories as follows: "Professionals", which include managers, engineers, social scientists, teachers, health occupations, and arts; “Other white-collar" occupations, which include clerical, sales, and service occupations; "Qualified blue-collar" occupations, which cover qualified workers in agriculture and the fishing industry, handcraft workers, mining and construction technical workers; "Non-qualified" occupations, which include jobs such as janitors, or non qualified laborers; and "Not working”, which includes both the unemployed and persons out of the labor force. ${ }^{26}$ The latter category is included because, as argued by Green 1999, it is an important part of immigrant adaptation and will likely vary between immigrants and native born.

\footnotetext{
${ }^{25}$ Although much of this result is due to the fact that we restricted the sample of immigrants to those arriving after 1990, we are not the first ones to find that the level of education of immigrants is not that different from that of natives (Dolado and Vázquez, 2007).

${ }^{26}$ Notice that the self-employed are included in our sample.
} 
There are at least five striking differences in the amount and type of change within the immigrant and native-born distributions across LFS years. First, while both population groups have shown a clear tendency of moving out of the "not working" category over the 2000-2008 period, the change has been considerably larger for immigrants arriving after 1999, with reductions of 20 to 28 percentage points, versus the-by no means negligible-reduction of 11 percentage points experienced by the native-born cohort. ${ }^{27}$ This shift out of the "not working” category for both population groups reflects the Spanish economic growth over the period under analysis. However, the fact that this trend is stronger for some, but not all, cohorts of immigrants, added to the observation that frequently the earlier cohorts show a movement similar or even smaller to that of the native population seems to suggest that part of what is going on is the assimilation of the immigrants. Second, the trend of this movement out of the "not working” category has also differed across the two populations. For the native-born population, the tendency has been gradual over the nine years, while for the immigrants most of the shift out of this category has occurred within the first two to three years after arrival to Spain, reflecting the initial assimilation process that this population experiences.

Third, the destination of these individuals has also differed for the two groups. While the native-born population have seen an increase in the "professional", and, to a lesser extent, the "other white-collar" categories; the immigrant population has mainly moved into the "blue-collar" and, to a lesser extent, “other white-collar” categories. Among immigrants arrived within the last decade, there is a trend out of the

\footnotetext{
${ }^{27}$ Such reductions are not observed for the cohort arriving in 2001 and are considerably smaller for the cohort 2002. This is probably explained by the fact that, due to the 2001 crisis, immigrants entering during 2001 and 2002 did so with favorable job perspective, as reflected by the lower fraction of immigrants from these cohorts "not working" compared to the other cohorts. The reductions are also smaller for the most recent cohorts, that is, those arriving in the last three years. The data suggests that the smaller reductions are most likely a consequence of these immigrants still assimilating to the new country.
} 
"professional" category. Fourth, there is clearly a greater fluidity of the immigrant distribution relative to that of the natives, as several cohorts of immigrants experience changes within an occupational category of up to 17 percentage points over the decade, while no native born category changes by more than 7 percentage points. This greater fluidity of the immigrant distribution may well reflect a greater ability to adjust to economic changes.

Finally, when comparing the occupational distributions for earlier cohort of immigrants with those of the native born, we find that over-time natives have increased their likelihood of being in the "professional" category, and "other white-collar" category compared to immigrants from the 1990s. In contrast, the immigrant population is relatively more concentrated in "blue-collar" and "non-qualified" occupations. This seems to suggest that there has been a shift towards less manual jobs among the native population compared to a shift in the opposite direction for immigrants, providing some evidence that these two populations have become more complementary over time. Several recent papers have highlighted that native and immigrant workers of similar educational attainment specialize in different occupations and therefore do not compete for the same jobs, explaining the small effect the inflows of immigrants on the wages of the less-educated natives in the U.S. (Ottaviano and Peri, 2006) as well as in Spain (Carrasco et al., 2008b). For instance, Peri and Sparber, 2008, find evidence of imperfect substitutability between natives and immigrants of similar educational attainment in the U.S. Dustmann, et al. 2008, also show that natives and immigrants in the U.K. of comparable skills do not compete for the same jobs, and Carrasco et al., 2008b, and Amuedo and de la Rica, 2009, find evidence of immigrants and natives being imperfect substitutes within skill categories in Spain. ${ }^{28}$

\footnotetext{
${ }^{28}$ Carrasco et al., 2008b, use data from the 2002 Spanish Structure of Earnings Survey. Amuedo and de la Rica, 2009, use the EPA 1999-2007 and focus on low-skilled workers (with at most a high-school
} 


\section{Methodology}

In what follows, we examine the following two questions. First, we analyze whether immigrants are underutilized in Spain by comparing the occupational distribution of immigrants to that of their native counterparts, and how this native/immigrant differential evolves with immigrants' time in the host country. Second, we study how the occupational distribution of a given cohort changes with time since arrival in Spain. In essence, this is equivalent to analyze what Borjas, 1985, calls the "within-cohort" assimilation effect.

To conduct the above mentioned analysis, we estimate for each of the LFS a cross-sectional multinomial logit (MNL) model of occupational selection separately over each of the immigrant and native-born samples. ${ }^{29}$ The MNL model permits estimation of the effects of various characteristics of an individual on his choice from among a set of alternatives that do not have a natural ordering, occupations in this case. $^{30} 31$ The MNL for the immigrant sample can be rationalized using an index model in which the value of a particular occupational choice is represented by:

degree). Their analysis on substitutability of natives and immigrants is brief and descriptive, and not the focus of their paper.

${ }^{29}$ We ran separate MNL for immigrants and natives because many studies have pointed out the importance of taking into account differences between immigrants and natives in their returns to human capital, and labor market experience (Friedberg, 2000; and Fernández and Ortega, 2009). In Appendix Table A.5 the relative risk ratios for two separate MNL (one for immigrants and one for natives) are displayed so that all coefficients can be seen. In this specification, we have pooled all LFS-years together.

${ }^{30}$ We decided to use a MNL as opposed to an ordered logit because a priori there was no clear order, at least among certain occupations, such as white-collar or qualified blue-collar. While it is true that we could have followed the approach that Amuedo-Dorantes and de la Rica used in their 2007 paper, which involves using earnings data (from a separate dataset, as the LFS does not have earnings information) to devise an occupational ranking, we decided against that option for several reasons. First, their approach ordered occupations based on a single job dimension: average earnings within an occupation. Clearly other dimensions may intervene in ordering occupations, such as skill requirements (qualified blue-collar jobs may require more skills than other white-collar occupations) or social status (white-collar jobs may be considered of higher status than qualified blue-collar jobs), among others. Moreover, because they used census data, the extremely large sample sizes in Amuedo-Dorantes and de la Rica, 2007 allowed them to classify jobs into as many as 22 categories, making it extremely useful to order them based on one dimension: earnings. In contrast, in our paper, the smaller sample sizes (especially for immigrants) only allowed us to define few and broad occupation categories. Given the reduced occupational choices in our paper and the focus of our paper on an alternative measure of assimilation (to the standard earnings assimilation one), led us to conduct the analysis without imposing a particular order among the different 


$$
I_{c t i}^{j}=X_{c t i} \beta_{c t}^{j}+\varepsilon_{c t i}^{j}
$$

where $j$ indexes the alternative, $c$ indexes the years-since-arrival to the host country by the immigrant, $t$ indexes the LFS year, and $i$ indexes the individual, $X_{c t i}$ is a vector of person-specific characteristics, $\beta_{c t}^{j}$ is a parameter vector that varies by alternative and LFS year, $\varepsilon_{c t i}^{j}$ is an error term. The probability that individual $i$ who arrived $c$ years ago chooses alternative $j$ in period $t$ is the probability that $I_{c t i}^{j}>I_{c t i}^{k}$ for all $k \neq j$.

Assuming $\varepsilon_{c t i}^{j}$ follows an independent extreme value distribution, the resulting specification for the choice probabilities will be a MNL model with years-since-arrival dummies and LFS-year dummies. Estimating the following equation for immigrants,

$$
\operatorname{Pr}\left(y_{c t i}=j\right)=\frac{\exp \left(X_{c t i} \beta_{j}\right)}{1+\sum_{k=1}^{J} \exp \left(X_{c t i} \beta_{k}\right)}
$$

for the reference category,

$$
\operatorname{Pr}\left(y_{c t i}=1\right)=\frac{1}{1+\sum_{k=1}^{J} \exp \left(X_{c t i} \beta_{k}\right)}
$$

we obtain estimates of the fitted probabilities of choosing alternative $j$ for immigrants:

$$
\hat{P}_{c t i}^{j}=X_{c t i} \hat{\beta}_{c t i}^{j}
$$

For native-born individuals, a similar index model is used but omitting the region of birth dummy variables and years-since-arrival dummy variables, as explained below. Estimating the following equations for native-born individuals,

categories. The MNL approach is not uncommon when analyzing a model of occupational choice (see Green, 1999, and Weiss et al., 2003, among others).

${ }^{31}$ While the MNL has the disadvantage that the relative odds of choosing any one option over another is unrelated to the introduction of further options, we are unable to estimate the multinomial probit (MNP), which allows relaxation of the independence assumption, because individuals are observed making only one occupational choice, and therefore a correlation matrix cannot be estimated with these data. 


$$
\operatorname{Pr}\left(y_{n t i}=j\right)=\frac{\exp \left(X_{n t i} \beta_{j}\right)}{1+\sum_{k=1}^{J} \exp \left(X_{n t i} \beta_{k}\right)}
$$

for the reference category,

$$
\operatorname{Pr}\left(y_{n t i}=1\right)=\frac{1}{1+\sum_{k=1}^{J} \exp \left(X_{n t i} \beta_{k}\right)}
$$

we obtain estimates of the fitted probabilities of choosing alternative $j$ for natives:

$$
\hat{P}_{n t i}^{j}=X_{n t i} \hat{\beta}_{n t i}^{j}
$$

The variables used to explain choices among these alternatives include sex, age, education, marital status, and LFS-year dummies. In addition, a set of location dummy variables are included because immigrants tend to exhibit different location patterns from the native born. For immigrants, a second set of variables is also used. These include: (1) a set of dummy variables corresponding to the region of birth to pick up differences in assimilation that might be related to regional characteristics, and (2) years-since-arrival dummy variables. In all regressions, we use sampling weights.

Comparison of the fitted probabilities between a representative immigrant (equation 3) and a representative national (equation 5) with similar observable characteristics of choosing alternative $j$ at a given LFS survey year $t$-as reflected by equation 6 below-, provides some insight into whether the immigrants' resource is being valued in the same way as that of comparable natives.

$$
\left(\hat{P}_{c t i}^{j}-\hat{P}_{n t i}^{j}\right)
$$

We shall estimate these differences in fitted probabilities between a representative immigrant and national as time in the country increases for the 
immigrant. $^{32}$ While these cross-sectional estimates will inform us on the assimilation process of a representative immigrant, they will also reflect the immigrants' timeinvariant cohort effect and how this cohort experiences changes in the economy (relative to natives).

To isolate the net assimilation effect, we shall compare the same cohort across LFS years (using again the native born as a comparison group to eliminate the effects due to changes in the economy) — this is what Borjas, 1985, calls the "within-cohort" effect. As such, comparisons of the fitted probabilities of choosing alternative $j$ for a representative immigrant who arrived $c$ years ago during the LFS year $(t-k)$ and the fitted probabilities of choosing alternative $j$ for that same type of immigrant $k$ years later (normalized by the changes observed in the fitted probabilities experienced by a representative native over the same time period) yields:

$$
\left(\hat{P}_{(c+k) t i}^{j}-\hat{P}_{c(t-k) i}^{j}\right)-\left(\hat{P}_{n t i}^{j}-\hat{P}_{n(t-k) i}^{j}\right)
$$

, which is an estimate of the net assimilation effect, assuming that immigrants and natives experience change in the economy in the same way.

While assuming that natives and immigrants experience economic changes in the same way may seem a reasonable assumption given that we are only analyzing a period of nine years, several authors have found evidence against this for the UK and Germany (see for instance Dustmann et al., 2009). In our exploratory work, we have examined whether there were trends in unobservable differences across cohorts, by comparing the fitted probabilities for a representative immigrant from different cohorts observed at the same number of years after arrival in Spain, again normalizing for changes experienced

\footnotetext{
${ }^{32}$ Observing how these differences vary as immigrants' time in Spain increases delivers, in essence, the same analysis presented in Amuedo-Dorantes and de la Rica, 2007, where they use the 2001 Census to estimate immigrants' assimilation relative to natives. The authors acknowledge that, because they only have a single cross-section, their estimates will be biased if the quality of immigrants across cohorts changes. However, they argue that the quality of immigrants across cohorts has remained unchanged over their sample period as they only focus on immigrants who have arrived within the last 5 years.
} 
by the native born over the same time period) — this is what Borjas, 1985, calls the "across-cohort" effect. Any observed differences in these estimates would either reveal that there were unobserved quality differences across the different cohort of workers or that immigrants and natives reacted differently to economic change. Perhaps not surprisingly, given the short period horizon, we did not find evidence of major differences (Fernández and Ortega, 2008, also corroborate this result for Spain over the same sample period and dataset).

\section{Empirical Results}

\section{V.1. Are Immigrants Valued the Same Way as Comparable Natives?}

In this section, we explore whether immigrants are valued the same way as comparable natives in Spain by comparing the occupational distribution of immigrants to that of their native counterparts. In addition, we analyze how this native/immigrant differential evolves with immigrants' time in the host country. For simplicity of exposure, we plot differences in fitted probabilities of choosing alternative occupations between natives and immigrants as immigrants' time in Spain increases in Figures 1.A through 1.D. The estimates from these Figures are obtained by subtracting the probability that a nativeborn worker of a given type chooses a particular occupation from the probability that an immigrant of the same type chooses the same occupation at each LFS survey (as indicated by equation 6 above). ${ }^{33}$ Since these estimates are calculated at different years since arrival in Spain and for different cohorts of immigrants, they represent a crosssectional measure of assimilation. ${ }^{34}$ All differences are statistically significant from zero at the $5 \%$ level. $^{35}$

\footnotetext{
${ }^{33}$ As a reference, the fitted probabilities for natives are displayed in Appendix tables A.5 and A.6

${ }^{34}$ Given that the overall pattern was very similar across the different cohorts, we only plot the results for the 2002 cohort. Estimates and plots for the other cohorts are available from the authors upon request.

${ }^{35}$ To test the significance of the differences plotted in the figures in this section and the following one, we
} 
As summarized in Table 4, the analysis is done for the following seven types of workers: For native-born individuals, the type 1 person is a male living in Madrid, aged 35 to 39 years old, currently married, without a high-school degree. For immigrants, that person is from Latin America and arrived in Spain in 2002. Type 2 is the same as type 1 but with a high-school degree. Type 3 is the same as type 1 but with vocational training or some college. Type 4 is the same as type 1 but with a university degree. Type 5 is the same as type 4 but comes from the EU15. Type 6 is the same as type 3 but comes from all Eastern European countries. And Type 7 is the same as type 1 but comes from Africa. ${ }^{36}$

Types 1 through 4 are displayed in Figure 1.A and types 5, 3, 6 and 7 are displayed in Figure 1.C. ${ }^{37}$ Figures 1.B and 1.D report results for women. A positive estimate implies that immigrants are over-represented in a given category relative to natives with similar observable characteristics. For instance, in the top LHS panel of Figure 1.A, the first bar height in the "non-qualified" category indicates that immigrant males without a high-school degree who arrived in Spain in 2002 are 15 percentage points more likely to hold a job in a "non-qualified" occupation in 2002 than their natives counterpart. The results are summarized below and clearly show that immigrants are underutilized in Spain as they are over-represented into low-skilled occupations and very little convergence towards natives occupational distribution is observed..$^{38}$

have ran a MNL model with both natives and immigrants (allowing for different coefficients in the sociodemographic covariates), and proceeded to test the significance of the difference for each case.

${ }^{36}$ Given that the focus of this paper is on how immigrants assimilate in Spain (as opposed to analyzing whether immigrants of different origins with identical observable characteristics assimilate differently), when choosing types by continent of origin, we decided to choose them based on the average education level for each group in Spain, as opposed to holding education constant across different origins.

${ }^{37}$ Note that type 3 is plotted twice.

${ }^{38}$ Although not shown, the analysis was also done for an eight type who was the same as type 3 but aged 25 years old instead. Whenever appropriate we include the results in the text. Estimates are available from the authors upon request. 


\section{V.1.a. Results for Males by Education Group}

Figure 1.A. shows that, compared to natives, immigrants are over-represented in the “non-qualified” category, regardless of their education level or time spent in the country (implying that full assimilation does not occur). Moreover, this relative overrepresentation of immigrants in "non-qualified” jobs is large, representing a hefty 10 to 20 percentage-points difference or more. It is also quite striking that this native/immigrant's differential does not change with worker's education level.

Figure 1.A. also shows that, compared to natives, immigrants without a college degree are under-represented in the "not working” category—if not immediately after arrival, within two to three years. Moreover, this under-representation increases at two to three after arrival in Spain. This pattern clearly suggests that low-skilled immigrants come to Spain to work. For high-school dropout immigrants, there is an initial underrepresentation in the "not working" category relative to their native counterparts, and this under-representation increases after two or three years in the country. For immigrants with a high-school degree or trade certificate, an under-representation in the "not working” category relative to their native counterparts arises two to three years after arriving in the country. In contrast, for immigrants with a college degree, we observe an initial over-representation in the "not-working” category compared to their native counterparts hovering 5 percentage points for males. Two or three years after arrival this over-representation of college immigrants in the "not working" category looses relevance.

Figure 1.A. also suggests that there is some convergence between low-skilled male immigrants and natives in "qualified blue-collar" occupations around three to five years after arrival in Spain. For low-skilled male immigrants (that is, those with a highschool degree or less), there is an initial under-representation in the "qualified blue- 
collar" category relative to their native counterparts that decreases with time in the host country, and seems to disappear three (five) years after arrival for high-school graduates (high-school dropouts)—as shown in the top charts of Figure 1.A. Moreover, for highschool graduates, after five years in Spain, they are slightly over-represented in this category relative to their native counterparts.

The bottom two charts of Figure 1.A. show no signs of convergence for highskilled male immigrants as they tend to concentrate into "qualified blue-collar" jobs and "non-qualified” jobs, regardless of their time since arrival. Relative to natives, male immigrants with a trade certificate are over-represented in the "qualified blue-collar" and "non-qualified" categories and under-represented in the "professional" and "other white-collar" categories. There is no apparent trend suggesting some convergence as time in Spain increases. The findings for young male workers with a trade certificate (not shown) or male immigrants with a college degree are very similar. The major difference is the relative concentration in the different categories for the most educated type. For instance, compared to natives they are under-represented in the "professional" category and slightly over-represented in the "other white-collar” category.

\section{V.1.b. Results for Females by Education Group}

As for males, Figure 1.B. shows that, relative to natives, immigrant women are overrepresented in "non-qualified” jobs, regardless of their education level and the years since arrival. Moreover, the relative difference between immigrant and native women doubles that observed among men as it ranges between the two and four-digit range. However, in contrast with the male findings, the gap between natives and immigrants decreases with women's skill level. Figure 1.B also shows that, compared to natives, immigrant women without a high-school degree are under-represented in the "not 
working” category, and this under-representation increases during the first few years after arrival in Spain, suggesting that low-skilled female immigrants also come to Spain to work. Finally, except for a shy reduction in the relative under-representation of immigrants in the "other white-collar" occupations category for women with a highschool degree or some vocational training, we do not observe any signs of convergence in the occupational distribution of female immigrants and their natives counterparts as time in Spain increases.

\section{V.1.c. Results by Country of Origin}

The top RHS chart and the bottom LHS chart in Figure 1.D show that coming from Latin America reduces the differential between female natives and immigrants' fitted probabilities of being in "non-qualified" and "other white-collar" categories relative to the same differential observed between natives and eastern Europeans by about close to 10 percentage points. Notice however that the differential pattern between Latin American and eastern Europeans is constant over time, suggesting that knowing Spanish at arrival (and/or the cultural proximity of coming from Latin America) gives a slight comparative advantage in the labor market to female immigrants that does not fade away with time in the country.

In contrast, no such language or cultural advantage is observed among males. The top RHS chart and the bottom LHS chart in Figure 1.C show that the difference in the native/immigrants occupational fitted distribution between Latino immigrants and their eastern European counterparts is merely a shift in the distribution between "other white-collar" and "blue-collar" occupations. Latino male immigrants are less underrepresented in the former category, whereas European immigrants are more overrepresented in the latter category. 
Also worth highlighting is that immigrants with a college degree from the EU15 (shown in the top LHS chart of Figures 1.C and 1.D) are the only ones for whom we do not observe an over-representation in the "non-qualified" category. ${ }^{39}$ In addition, (and probably not surprisingly) this group's fitted occupational distribution is closest to that of their native counterparts, revealing that coming from the neighboring EU15 countries facilitates entering the labor market and finding jobs similar to those of natives.

Finally, African immigrants without a high-school degree (shown in the bottom RHS chart of Figures 1.C and 1.D) also diverge in several aspects to other immigrants who are also high-school dropouts (top LHS chart in Figures 1.A. and 1.B.). To begin with, African immigrants are heavily over-represented in the "non working” category during the first couple of years after arrival in Spain. This sizeable difference of about 10 percentage points decreases considerably after African immigrants have been in the country for three to four years. However, and in contrast with low-skilled immigrants from other origins, they are never under-represented in this category relative to natives, reflecting the difficulties of finding jobs for this group of immigrants. Similarly, there is no convergence between low-skilled African males and their native counterparts in the "qualified blue-collar" category as we had observed for similar immigrants coming from other origins. In this case, although the under-representation of African immigrants in this category decreases with time in the host country, it does not vanish even after 6 years in the country. ${ }^{40}$

\section{V.2. What Is the Assimilation Process of Immigrants in Spain?}

In what follows, we address the following question: For a given cohort, how does the occupational distribution change with time since arrival in Spain? In essence, this is

\footnotetext{
${ }^{39}$ These two charts ought to be compared to the bottom RHS chart in Figures 1.A. and 1.B.

${ }^{40}$ This non-convergence also holds for cohorts who have been longer in the country.
} 
equivalent to analyze the net assimilation effect, which compares the change observed in the fitted probabilities experienced by the same cohort of immigrants at different points after arrival to the host country (net of the changes observed in the native population over the same time period)—as shown by equation 7 above. ${ }^{41}$ Figures 2.A through 2.D show the change in occupational distribution for the different types described in Table 4, as their time in Spain increases. ${ }^{42}$ In this case, a positive estimate implies that there is an over-representation for a particular cohort of immigrants in a given occupation category compared to that same cohort $t$ years earlier (net of the changes that have occurred within that same period among the natives). ${ }^{43}$ For instance, in the top LHS panel of Figure 2.A, the sixth bar height in the "blue-collar" category indicates that male immigrants without a college degree who arrived in Spain in 2002 are 13 percentage points more likely to hold a job in a "qualified blue-collar" occupation in 2008 than in 2002 when they first arrived, relative to the change observed over the same period in the same occupational category among their natives counterparts. The findings are summarized below.

\section{V.2.a. Results for Males by Education Group}

For male immigrants without high-school degree, the patterns observed in the "nonqualified" and "qualified blue-collar" categories in the top LHS chart of Figure 2.A. clearly suggest an assimilation effect as recently arrived immigrants adjust to the new economy. Within the first few years after arrival, immigrants without a high-school degree first move to "non-qualified" jobs (as shown by the positive estimates for the “non-qualified” category). However, within a couple of years after arrival, they begin

\footnotetext{
${ }^{41}$ Notice that the estimates are relative to the year of arrival (not to the previous year).

${ }^{42}$ Again, the overall pattern was very similar across the different cohorts of immigrants, and consequently we only plotted the results for the 2002 cohort. Estimates and plots for the other cohorts are available from the authors upon request.

${ }^{43}$ As a reference, the fitted probabilities for natives are displayed in Appendix tables A.5 and A.6
} 
to shift out of "non-qualified” jobs and "not working” category towards "qualified bluecollar" occupations. Notice that the move into "qualified blue-collar" occupations occurs around the second and third year after arrival in Spain.

Perhaps surprisingly, a very similar assimilation pattern is observed for male workers with a high-school degree (as shown in the top RHS chart of Figure 2.A). The differences across these two education groups are practically inexistent, suggesting that having a high-school degree does not give immigrants an advantage in terms of the process of assimilation in Spain nor the occupations where they end up working in. Moreover, given that the odds of being in the "professional” and "other white-collar" categories increases with the possession of a high-school degree for natives, ${ }^{44}$ this finding suggest that the degree of assimilation is highest the lower the education level of immigrants, as those with a higher skills segregate in the same occupations as those with lower skills.

This finding is confirmed when observing the change in the predicted occupational distribution of immigrants with vocational training or a college degree (bottom charts of Figure 2.A). In contrast with the results found for high-school dropouts, no such assimilation seems to take place among high-skilled male immigrants. Male immigrants with vocational training shift into "non-qualified” occupations during the first couple of years after arrival, and it is not until the third year after arrival that they move into "qualified blue-collar" occupations. A similar pattern is observed for college male immigrants, although their speed of assimilation towards "qualified bluecollar" jobs is faster. ${ }^{45}$ This result is consistent with the work of Amuedo and de la Rica, 2007, who also found that there was little occupational assimilation of male

\footnotetext{
${ }^{44}$ While high-school dropout natives have a fitted probability of being in either category of about $8 \%$ and $9 \%$, respectively; for high-school graduates these fitted probabilities increase to $13 \%$ and $16 \%$, respectively.

${ }^{45}$ Notice that the flow out of the "professional" category most likely reflects some returned migration.
} 
immigrants with university degrees (relative to similarly skilled natives). These authors were surprised by this remarkable finding and gave it little importance by explaining that "the apparent lack of upward occupational assimilation on the part of immigrant men with university degrees could be simply driven by the limited number of observations." 46 As we explain in Section VI, we believe there is an explanation for this remarkable result: the dual structure of the Spanish labor market.

\section{V.2.b. Results for Females by Education Group}

The assimilation pattern of low-skilled female immigrants reveals that they are in a more vulnerable situation than their male counterparts, as no catching up seems to take place. The top two charts of Figure 2.B show that low-skilled female immigrants move from the "not working" and "other white-collar" categories into the "non-qualified" category during the first years after arrival. However, in contrast with the "catching up" observed among low-skilled male immigrants into the "qualified blue-collar" category, no "catching up" takes place for low-skilled women in the "other white-collar" category.

While education among high-skilled female immigrants seems to help their assimilation process a bit, they are far from converging to their native counterparts, as observed earlier for skilled male immigrants. Right after arrival, female immigrants with a trade certificate or a college degree shift out of the "professional" and "other white-collar" categories into "non-qualified” occupations. However, very soon thereafter, the flow goes from "not working" and "professional” categories into "nonqualified" occupations and (within three years after arrival) into "other white-collar" occupations.

\footnotetext{
${ }^{46}$ Recently, Hartog and Zorlu, 2009, find a similar results in The Netherlands. They find that higher education acquired at home for refugees in The Netherlands did not generally pay off during the first five years in the Dutch labor market.
} 


\section{V.2.c. Results by Country of Origin}

There are very few differences in the assimilation process of Latin American and eastern Europeans immigrants (top RHS and bottom LHS charts of Figures 2.C and 2.D), suggesting that language or cultural proximity have little effect in terms of speeding assimilations — and consistent with findings from Section V.1.c that whatever comparative advantage is provided by the language, there is no catching up as eastern Europeans acquire those skills.

The assimilation process of African high-school dropout males clearly shows how they move from the "not working” category into the "non-qualified” category over the first year after arrival and the "qualified blue-collar" category thereafter (as shown in the RHS bottom chart of Figure 2.C). However, their shift out of the "non-qualifies" category and into the "qualified blue-collar" category is takes longer than that observed for other immigrants without a college degree (top LHS chart of Figure 2.A).

\section{Channels through which Assimilation Takes Place}

In this section, we present two alternative theories (human capital theory and segmented labor markets) with distinct predictions to help us understand the channels that explain immigrants' assimilation process after arrival into Spain. As we shall see, the results presented thus far are consistent with the segmented labor market hypothesis. We conclude this section with two robustness checks that provide additional empirical support for this hypothesis.

Human Capital Theory. Eckstein and Weiss, 2004, develop a human capital model in which different skills are rewarded differently at different occupations, and that describes the investment decisions of immigrants and natives. The added value of this model is that there is an explicit introduction of a time-since-arrival effect on prices of 
skills that influence the immigrants' investment decision process. The acquisition of new skills requires some sacrifice of current earnings. The investment decisions interact with the changes in the market value of the immigrant's skills and together determine his earnings growth. In particular, rising prices for imported skills provide an added incentive for investment because the sacrifice of current earnings is low relative to the growth in future earnings capacity. In their model, immigrants fully assimilate if the prices of imported skills converge to the same price as that obtained by natives for locally produced skills, because increasing prices on imported human capital imply higher investment by immigrants. However, if imported skills are of lower quality and so their long-run prices falls short of the value of the locally acquired skills, then earnings of immigrants may never catch up with those of natives. Such a model implies that assimilation or convergence ought to be easier among higher educated immigrants and those coming from countries with higher compatibility of the human capital received abroad with the skill requirements of the host-country labor market as it ought to be easier for them to build up the host country's labor market specific human capital because of the greater complementarity between pre- and post-migration human capital. $^{47}$

Segmented Labor Markets. According to the dualistic view, the labor market is segmented by two types of jobs: those in the primary sector, characterized by jobs with high-productivity growth and good benefits and chances of promotion, and those in the secondary sector, where less productive jobs with little or no benefits are found. Under such view, individuals working in the secondary sector are frequently seen as the disadvantaged segment of the labor force rationed out of salaried employment (Fajnzylber and Montes Rojas, 2006). In other words, workers with little access to the

\footnotetext{
${ }^{47}$ In this model, transitions up the occupational scale occur exogenously and are fully anticipated. Cohen and Eckstein, 2002, estimate a structural model in which occupational switches and investment decisions are jointly determined and find similar predictions.
} 
primary labor market enter the secondary sector while queuing for wage and salary jobs.

Since more vulnerable groups of native workers, such as low-skilled workers, youth, and women, tend to be concentrated in the secondary labor market (Kahn, 2007; and Estrada et al., 2009, among others), converging towards their occupational distribution ought to be relatively easier for low-skilled immigrants than the convergence process of high-skilled immigrants towards the occupational distribution of high-skilled natives, who are likely to be concentrated in the primary labor market.

In this paper, we find that in Spain male immigrants with a high-school degree or less converge towards the occupational distribution of similarly skilled natives, but that no assimilation seems to take place among those with a university degree. This result is consistent with segmented labor markets, and against the human capital hypothesis. Note however, that this does not necessarily imply that low skilled immigrants are better off than high skilled ones because, for each case, assimilation is measured in relation to an observationally similar native. ${ }^{48}$

To corroborate this result, we do the following two robustness checks. First, we analyze how the proportion of immigrant and native workers with permanent contracts changes the longer the immigrants have been in the country by education level. Second, using an alternative dataset, we analyze whether earnings assimilation of immigrants with time in the host country is higher for the least skilled workers.

\section{Incidence of Permanent Contract}

Table 5 shows the incidence of permanent contracts among natives and immigrants by education level and gender. As expected, we find that the likelihood of having a permanent contract versus a fixed-term one is higher for the most educated workers

\footnotetext{
${ }^{48}$ Suppose that an electrical engineer from Peru ends up working as an electrician after 7 years in Spain, and that a high-school dropout from the same country ends up having a construction job after 7 years. The former is most likely in a better job. However, relative to a similarly skilled native, the high-school dropout immigrant has assimilated better than the electrical engineer.
} 
(81.68\% for male native workers and $60.06 \%$ for male immigrant workers) and lower for the least educated (67.61\% for male native workers and $36.00 \%$ for male immigrant workers). In addition, Table 5 shows that the incidence of permanent contracts is higher among natives than immigrants, regardless of the skill level or the gender. Finally, we find that for males the difference between immigrants and natives in the incidence of having a permanent contract is smaller (albeit a significant 21 percentage points) for workers with a university degree. No such differential pattern is observed across education levels for women. Clearly, these comparisons are flawed in several ways as they do not control for LFS year dummies, age or cohort effects.

To accurately analyze assimilation rates, we have estimated how the probability of having a permanent contract changes with time in the host country for immigrants relative to similarly skilled natives separately for three educational levels and by gender (shown in Table 6). While this approach is similar to that of Fernández and Ortega, 2008, it differs in that we analyze the assimilation pattern separately for three different educational levels: high-school dropouts, high-school graduates and university graduates. ${ }^{49,50,51}$ According to Panel A, male immigrants who arrived to Spain between 2000 and 2004 where about 35 percentage points less likely to have a permanent contract than a native with similar characteristics (for this cohort, there were little differences across education levels in the likelihood of having a permanent contract at arrival). ${ }^{52}$ Panel A also shows that the assimilation into permanent jobs is faster for

\footnotetext{
${ }^{49}$ Fernández and Ortega, 2008, allow for a differential immigrant effect by education level, but assume the same assimilation pattern across the different school levels.

${ }^{50}$ We have done this analysis for three education levels, as opposed to four as in the main text because of sample size limitations of the immigrant population. In the occupational analysis, similar sample size restrictions led us to do the analysis pooling both genders and education levels (in that case, each crosssectional multinomial logit was estimated for each individual LFS year).

${ }^{51}$ The analysis is restricted to wage and salary workers.

${ }^{52}$ This pattern varies across cohorts, for instance, male immigrants who arrived after 2004 with a highschool degree or less were 44 percentage points less likely to have a permanent job than a similarly skilled native. In contrast, male immigrants with a university degree were "only" 35 percentage points less likely to have a permanent contract than a native with similar characteristics.
} 
immigrants without a high-school degree than for those with a university degree. For instance, for male immigrants without a high-school degree, their differential in the incidence of permanent contracts is reduced by a significant 9 percentage points after 10 years in the host country, while for immigrants with a high-school degree, this differential is only reduced by 4 percentage points after 10 years. Finally, for male immigrants with a university degree there is no convergence. This finding is inconsistent with the human capital hypothesis, which would have predicted higher assimilation into the primary labor market for the more skilled immigrants. In contrast, it supports the dualistic view of the labor market as it implies that it is easier for lowskilled immigrant workers than for the higher skilled ones to converge towards permanence rate of similarly skilled natives.

\section{Earnings Assimilation}

As explained earlier the Spanish LFS has no earnings information. However, a recently available dataset, the 2005 Continuous Sample of Working Histories (CSWH) provides rich information about labor market histories from 1980 to 2005 coming from Social Security Administrative records. This is the dataset used by Izquierdo et al., 2009, to estimate the earnings assimilation of immigrants in Spain. Using the same data sample than Izquierdo et al., 2009, and the same empirical specification, we estimated earnings assimilation for three different sub-populations: (1) those working in low-skilled jobs (not requiring a high-school degree); (2) those working in medium-skilled jobs (requiring a high-school degree); and (3) those working in high-skilled jobs (requiring a university degree). The reason for using these skill categories as opposed to the education level of the individual is that the only variable recording education in the CSWH comes from the Spanish Municipal Registry of Inhabitants and was last updated in 1996, which leads to important underestimates of true education (especially for 
natives relative to immigrants as the latter are much more likely to have registered their education in a later date). Fortunately for us, the CSWH provides its own classification of jobs based on their different skill requirements. This is the classification that we use. Table 7 shows the earnings assimilation results for male immigrants by skill level. As in Izquierdo et al., 2009, we restrict the sample to wage and salary male workers between 25 and 54 years old who started their labor career after $1979 .^{53}$ The last column is the specification for the whole sample- that is, the same as in Izquierdo et al., 2009, in column (2) of Table 2. The first three columns display the results for the low-, medium-, and high-skill workers, respectively. The following two results emerge. First, the coefficient in front of the assimilation dummies are always larger in the first and second columns than those in the third column, implying that earnings assimilation of immigrants (compared to similarly skilled natives) is faster for those working in jobs requiring a high-school degree or less than for those in jobs requiring a university degree. Second, comparing the coefficients in front of the dummy regarding the first 13 years in the country, those in the lower skilled group see their initial wage gap relative to natives decrease 29 percentage points, more than double the decrease observed over the same time period for those in the middle group and almost five times higher than the decrease observed for those with the highest skill level. This result suggests that earnings convergence is higher in the lower skill category jobs, which provides additional support for the segmented labor market hypothesis.

\footnotetext{
${ }^{53}$ Because the CSWH has been designed to be representative of the labor market in the year 2005, the sample loses representativeness for previous years if the sample of individuals who do exit the Social Security records is not random. As the authors explain, this is particularly relevant for youth and women. Izquierdo et al., 2009, address this problem by focusing on males working in the formal sector.
} 


\section{Discussion and Further Research}

From our empirical investigation the following three findings stand out: First, immigrants in Spain are more occupationally mobile than natives. Most of this greater flexibility is explained by immigrants' assimilation process soon after arrival to the host country: Just after arrival, immigrants enter occupations below their skill level and then move towards higher skilled occupations. However, our second finding indicates that convergence does not occur: Immigrants are not valued the same way as comparable natives, even after assimilation to the new labor market, language and country has taken place, as they segregate into low-skilled occupations (compared to natives with similar observable characteristics) — this reflects the lack of full transferability of their imported observable skills, and/or labor discrimination. Third, we find that, among male immigrants, the level of assimilation is higher the lower the education level.

The first two findings imply that, within the same skill group, immigrants and natives may not be perfect substitutes, as recently found by others—see Ottaviano and Peri, 2006, and Card and Shleifer, 2009 for the US; Manacorda et al., 2006, and Dustmann et al., 2009, for the UK; D’Amuri et al., 2008, for Germany; and Carrasco et al., 2008b, and Amuedo and de la Rica, 2009, for Spain. In addition, our finding that assimilation is stronger the lower the education level for male immigrants provides evidence consistent with segmented labor markets, and rejects the human capital theory. In an economy with a dual labor market, immigrants assimilate better if they are lowskilled. This occurs because native low-skilled workers are more likely to work in the secondary market or low-skilled jobs, which is of easier access to immigrants, facilitating the convergence between immigrants and their native counterparts. Finally, we have provided additional evidence consistent with segmented labor markets by 
analyzing the assimilation process of earnings and of incidence of permanent jobs by different skill levels.

An alternative and complementary explanation for this result is the need for certification. Several occupations that require high levels of education also require certification in the destination country. This is clearly the case in the Spanish labor market, and not only for architects, physicians, or lawyers, but also for electricians, plumbers, and the like. While certification may have a basis in country specific required skills, it also may have elements of discrimination and job protection. Unfortunately, without further data, we cannot differentiate between these explanations. ${ }^{54}$

Should we interpret the lack of this finding among female immigrants as evidence against the dual labor market theory? Not necessarily. The fact that immigrant women are further marginalized seems to indicate that in a segmented labor market, new "underclasses" of workers may appear among the most vulnerable individuals-Fernández-Kranz and Rodríguez-Planas, 2009, also find that the dual structure of the Spanish labor market further aggravates the situation of the most vulnerable workers in the secondary labor market. Much of this imperfect substitutability between natives and immigrants in Spain might be explained by the segmentation of the labor market, which, if true, leads to major concerns on potential efficiency losses for the Spanish economy. ${ }^{55}$ Important topics for further research include the following two questions: What are the consequences for the Spanish economic growth of undervaluing this large inflow of high-skilled immigrants? And second, now that a major recession is taking place, what are the social, economic, and

\footnotetext{
${ }^{54}$ Recently, Hartog and Zorlu, 2009, find that higher education acquired at home for refugees in The Netherlands did not generally pay off during the first five years in the Dutch labor market. One of the explanations that the authors put forward is the need for certification.

${ }^{55}$ Amuedo and de la Rica, 2009, explore the reasons for this imperfect substitution among low-skilled workers and find evidence that low-skilled natives relocate to jobs with a lower content of manual tasks. However, what seems more policy concerning is to understand the reasons for the imperfect substitution among high-skilled workers as these may be the source of economic inefficiencies.
} 
welfare consequences of having so many immigrants in the most vulnerable jobs, and therefore those most likely to suffer from job destruction? Policy proposals aiming at adding labor market flexibility and eliminating rigid and dual labor market structures will most likely enhance an efficient allocation of labor.

\section{REFERENCES}

Amuedo-Dorantes, C. 2000. "Work Transitions Into and Out of Involuntary Employment in a Segmented Market: Evidence from Spain,” Industrial Labor Relations Review, 2000, 53(2): 309-325.

Amuedo-Dorantes C., De la Rica S. 2005. "Immigrants’ Responsiveness to Labor Market Conditions and its Implications on Regional Disparities: Evidence from Spain.” IZA Discussion Paper No. 1557.

2007. "Labor Market Assimilation in Spain.” British Journal of Industrial Relations 45:2: 0007-1080 pp. 257-284.

2008. “Does Immigration Raise Natives' Income? National and Regional Evidence from Spain” IZA Discussion Paper No. 3486.

2009. "Complements or Substitutes? Immigrant and Native Task Specialization in Spain.” IZA Discussion Paper No. 4348.

Andrés J. 2009. “España y los Desequilibrios Globales”, Libro Electrónico Sociedad AbiertaFedea: "La Crisis de la Economía Española: lecciones y propuestas”, 09/02/2009.

Aydemir A., and G. Borjas, 2007. "Cross-Country Variation in the Impact of International Migration: Canada, Mexico, and the United States," Journal of the European Economic Association, MIT Press, vol. 5(4), pages 663-708, 06.

Baker, M., and D. Benjamin. 1994. "The Performance of Immigrants in the Canadian Labour Market.” Journal of Labor Economics 12, 369-405.

Barceló C. and E. Villanueva, 2010. "The response of household wealth to the risk of losing the job: evidence from differences in firing costs.” Banco de España Working Paper no. 1002

Barth, E., B. Bratsberg, and O. Raaum. 2004. "Identifying Earnings Assimilation of immigrants under changing macroeconomic conditions." Scandinavian Journal of Economics 106 (1), 1-22.

Barth, E., Bratsberg, B., Raaum, O. 2006. "Local Unemployment and the Relative Wages of Immigrants: Evidence from the Current Population Surveys.” Review of Economics and Statistics 88 (2), 243-263. 
Beaudry, P, and T. Lemieux. 1999. "Evolution of Female Labour Force Participation Rate in Canada, 1976-1994.” Mimeo Centre Interuniversitaire de Recherche en Analyse des Organisations.

Bell, B.D., 1997. "The Performance of Immigrants in the United Kingdom: Evidence from the GHS.” Economic Journal 107 (441), 333-344.

Bentolila, S. and J. Dolado. 1994. "Labour Flexibility and Wages: Lessons from Spain." Economic Policy 18: 53-99.

Borjas, G. 1985. "Assimilation, Changes in Cohort Quality, and the Earnings of Immigrants." Journal of Labor Economics, 4: 463-69.

1992. "National Origin and the Skills of Immigrants," in George J. Borjas and Richard B. Freeman, eds., Immigration and the Work Force, Chicago: The University of Chicago Press.

1995. "Assimilation and Changes in Cohort Quality Revisited: What Happened to Immigrant Earnings in the 1980s?” Journal of Labor Economics, 13: 201-45.

Bentolila, S., J. Dolado, and J. F. Jimeno 2008. "Does Immigration Affect the Phillips Curve? Some Evidence for Spain.” European Economic Review 52 (2008) 1398-1423.

Blau FD, LM Kahn. 2007. “Gender Assimilation among Mexican Americans.” In: Borjas G (ed) Mexican immigration. University of Chicago Press, Chicago (forthcoming)

Boyd, M. 1985. "Immigration and Occupational Attainment in Canada." In Ascription and Achievement: Studies in Mobility and Status Attain- ment in Canada, edited by M. Boyd, J. Goyder, F. E. Jones, H. A. McRoberts, P. C. Pineo, and J. Porter, pp. 383-445. Ottawa: Carleton University Press.

Card, D. 2005. “Is the New Immigration Really So Bad?” Economic Journal, 115.

Card, D, and J. Dinardo. 2000. “Do Immigrant Inflows Lead to Native Outflows?” American Economic Review, 90, May.

Card D., and A. Shleifer, 2009. "Immigration and Inequality," American Economic Review, vol. 99(2), pages 1-21, May.

Carrasco R., J.F. Jimeno, A.C. Ortega. 2008 a. "The Effect of Immigration on the Employment Opportunities of Native-Born Workers: Some Evidence for Spain.” Journal of Population Economics 21:627-648.

2008 b. "The Impact of Immigration on the Wage Structure: Spain 1995-2002." Universidad Carlos III working paper 08-16.

Chiswick, B. 1978 a. "The Effect of Americanization on the Earnings of Foreign-Born Men." Journal of Political Economy, 86: 897-921.

1978 b. “A Longitudinal Analysis of Occupational Mobility of Immigrants." in ed. Barbara Dennis, Proceedings of the 30th Annual Winter Meeting, Industrial Relations Research Association, December, 1977, Madison, Wisconsin, pp. 20-27.

Chiswick B. 1986. "Human Capital and the Labor Market Adjustment of Immigrants: Testing Alternative Hypotheses.” In Stark O (ed) Research in human capital and development: 
migration, vol 4. Jai, Greenwich, CT, pp 1-26

Chiswick B., P. Miller. 1995. "The Endogeneity Between Language and Earnings: International Analyses.” Journal of Labor Economics, 13(2):246-288

Chiswick, B., and P. Miller. 2006. “Immigration to Australia during the 1990's: Institutional and Labour Market Influences”, in D.A. Cobb-Clark and S. Khoo (eds.), Public Policy and Immigrant Settlement, Edward Elgar, Cheltenham, UK.

Cobb-Clark, D.A. 2000. "Do Selection Criteria Make a Difference? Visa Category and the Labour Market Status of Immigrants to Australia.” Economic Record, 76 (232): 15-31.

Cobb-Clark, D.A. (2003) "Public policy and the labor market adjustment of new immigrants to Australia”, Journal of Population Economics, 16: 655-681.

Cohen-Goldner, S and Z. Eckstein. 2002. "Labour Mobility of Immigrants: Training, Experience, Language and opportunities.” CEPR Discussion paper series No.3412

Constant A., and D. Massey. 2005. "Labor Market Segmentation and the Earnings of German Guestworkers.” Population Research and Policy Review, 2005, 24 (6), 5-30.

Cuñat V., and L. Garicano. 2009. “¿Para Cuando la Reestructuración del Sistema Financiero Español?” El País (Tribuna, 13/09/2009)

De la Rica, S. 2009. "De la Crisis Inmobiliaria y Financiera hacia la Recesión en el Mercado Laboral. Dónde Estamos y Hacia Dónde Debiéramos Ir“, Libro Electrónico Sociedad Abierta-Fedea: “La Crisis de la Economía Española: lecciones y propuestas”, 09/02/2009

De la Rica, S. 2004. "Wage Gaps between Workers with Indefinite and Fixed-Term Contracts: The Impact of Firm and Occupational Segregation." Moneda y Crédito 219: 43-69.

Dolado, J., R. Duce, and J.F. Jimeno. 1998. "Los Efectos de la Inmigración sobre la Demanda Relativa de Trabajo Cualificado, vs. Poco Cualificado: Evidencia para España." Cuadernos Económicos del ICE (1998),vol 63, pp11-30.

Dolado, J. J., F. Felgueroso, F., and J.F. Jimeno. 1999. “Los problemas del mercado de trabajo juvenil en España: empleo, formación y salarios mínimos.” Ekonomiaz, vol. 43, pp. 136-57.

Dolado, J., C. García-Serrano, and J.F. Jimeno. 2002. "Drawing Lessons from the Boom of Temporary Jobs in Spain,” Economic Journal, 112(480): F270-295.

Dolado, J., and Vázquez P. 2007. “Los Efectos Económicos y las Políticas de la Inmigración: Panorámica y Reflexiones.” Fedea Working Paper.

Domingo A., F. Gil, and E. Vidal. 2006. "Participation of Immigrants in the European Unions" National Labor Markets in a Context of Complementarity: Substitution and Competition with Local Labor Force.' Centre d'Estudis Demografics mimeo.

Duleep, H., and D. Dowhan. 2002. "Insights from Longitudinal Data on the Earnings Growth of U.S. Foreign-born Men.” Demography.

Duleep, O., and M. Regets. 2002. "The Elusive Concept of Immigrant "quality": Evidence from 1970-1990.”, IZA Working Paper No. 631. 
Dustmann, C., F. Fabbri, and I. Preston. 2005. "The Impact of Immigration on the British Labour Market”, Economic Journal, Volume 115, Issue 507, Page F324-F341.

Dustmann, C., T. Frattini, and I. Preston. 2008. "The Effect of Immigration along the Distribution of Wages.” CReAM Discussion Paper \# 03/08.

Dustmann C., A. Glitz, and T. Vogel. 2009. "Employment, Wages, and the Economic Cycle: Differences between Immigrants and Natives.” Europoean Economic Review.

Dustmann, C., T Hatton and I Preston. 2005. "The Labour Market Effects of Immigration.” editorial, Economic Journal, Volume 115, Issue 507, Page F324-F341.

Duvander A. 2001. "Do Country-Specific Skills Lead to Improved Labor Market Positions?: An Analysis of Unemployment and Labor Market Returns to Education among Immigrants in Sweden.” Work and Occupations; 28; 210

D’Amuri, F., G. Ottaviano, and G. Peri. 2008. “The Labor Market Impact of Immigration in Western Germany in the 1990’s.” FEEM Working Paper No. 16, 2008.

Eckstein, Z and Y. Weiss. 2004. “On the Wage Growth of Immigrants: Israel 1990-2000.” Journal of European Economic Association, June 2004, pp. 665-695.

Estrada A., M. Izquierdo, and A. Lacuesta. 2009. "Funcionamiento del Mercado de Trabajo y el Aumento del Paro en España.” Banco de España, 102 Boletín Económico, Julio-Agosto 2009.

Fajnzylber, M., and Montes Rojas. 2006. "Microenterprise Dynamics in Developing Countries: How Similar Are They to Those in the Industrialized World? Evidence from México.” The World Bank Economic Review, vol. 20: 389-419.

Fernández, C. and C. Ortega. 2008. "Labor market assimilation of immigrants in Spain: Employment at the Expense of Bad Job-Matches?”, Spanish EconomicReview, vol. 10, n. 2, pp. 83-107.

Fernández-Kranz D, and N. Rodríguez-Planas. 2009. "The Part-Time Penalty in a Segmented Labor Market.” IZA discussion paper No. 4342.

Flug, K., N. Kasir; and O. Gur. "The Absorption of Soviet Immigrants into the Labor Market from 1990 Onwards: Aspects of Occupational Substitution and Retention.” Bank of Israel Discussion Paper no. 9213. Jerusalem: Central Bank of Israel, April.

Friedberg, R. 1993. "The Labor Market Assimilation of Immigrants in the U.S: The Role of Age at Arrival," Brown University, 1993.

Friedberg R. 2000. "You Can't Take it with You? Immigrants Assimilation and the Portability of Human Capital: Evidence from Israel.” Journal of Labor Economics, 18 (2):221-251.

Friedberg, R. 2001. "The Impact of Mass Migration on the Israeli Labor Market." The Quarterly Journal of Economics, CXVI(4), November, pp.1373-1408.

Frijters, P., M. Shields, and S. Price. 2005. "Job Search Methods and their Success: A Comparison of Immigrants and Natives in the UK." The Economic Journal, 115 (November), F359-F376. 
Garicano L. 2008: “La Transición Económica Pendiente”, en Expansión el 05-12-2008

García-Ferreira M. and E. Villanueva, 2007. "Employment Risk and Household Formation: Evidence from firing costs.” Working Paper no 737, Banco de España.

Gil Alonso, F., and Domingo, A. 2007. "La Participación de los Ciudadanos Latinoamericanos en el Mercado de Trabajo Español: Características Diferenciales y Evolución Reciente (2000-2005)". V Congreso sobre la Inmigración en España. Migraciones y desarrollo humano. Valencia: Universidad de Valencia, pp. 62.

Gindling, T. 2009. "South-South Migration: The Impact of Nicaraguan Immigrants on Earnings, Inequality and Poverty in Costa Rica.” Forthcoming in World Development, 2009, 37(1), January.

Green D. 1999. “İmmigrant Occupational Attainment: Assimilation and Mobility over Time.” Journal of Labor Economics, vol., 17, no. 11: 49-79.

Green, D. 1995. "The Early Adjustment of Immigrants: Credentials Rec- ognition and Earnings Growth." Discussion Paper no. 95-12. Vancouver: University of British Columbia, Department of Economics.

Güell, M. and B. Petrongolo. 2007. "How Binding are Legal Limits?: Transitions from Temporary to Permanent Work in Spain”, Labour Economics 14, 153-183.

Hanson, G. 2008. "The Economic Consequences of the International Migration of Labor," NBER Working Papers 14490, National Bureau of Economic Research.

Hatton, T., and Williamson, J. 2005. “What Fundamentals Drive World Migration?” In

Borjas, G. \& Crisp, J. (Eds.), Poverty, International Migration and Asylum (pp. 15-38).

Hampshire, U.K.: Palgrave-MacMillan for Wider.

Harriet, O., and M. Regets, 1999. "Immigrants and Human-Capital Investment." American Economic Review, vol. 89(2), pages 186-191, May.

Hartog, J., and A. Zorlu. 2009. "How important is homeland education for refugees' economic position in The Netherlands?” Journal of Population Economics 22 (1): 219-246

Hernanz, V. 2002. "El Trabajo Temporal y la Segmentación: Un Estudio de las Transiciones Laborales.” Unpublished PhD Dissertation, Universidad de Alcalá de Henares, Madrid.

Hu W. 2000. "Immigrant Earnings Assimilation: Estimates from Longitudinal Data." A.E.R. Papers and Proc. 90 (May): 368-72.

Hu W-Y. 2000. "Immigrant Earnings Assimilation: Estimates from Longitudinal Data." American Economic Review 90: 368-372.

Hum D., and W. Simpson. 2000. "Closing the Gap: Economic Assimilation of Canadian Immigrants Reconsidered.” J Int Migr Integr 1:427-441.

Hum D., and W. Simpson. 2004. "Reinterpreting the Performance of Immigrant Wages from Panel Data.” Empirical Economics 29:129-147

Islam A. 2009. "The substitutability of labor between immigrants and natives in the Canadian labor market: circa 1995.” Journal of Population Economics, 22 (1): 199-218. 
Izquierdo M., Lacuesta A., Vegas R. 2009. “Assimilation of Immigrants in Spain: a Longitudinal Analysis.” Labour Economics (forthcoming).

Jimeno, J.F. and L. Toharia. 1993. "The Effects of Fixed-Term Employment on Wages: Theory and Evidence from Spain,” Investigaciones Económicas, 17(3): 475-494.

Jimeno, J. F., and L. Toharia. 1996. "Effort absenteeism, and fixed-term employment contracts.” Revista Española de Economía, vol. 13(1), pp. 105-19.

Khan, L. 2007. "The Impact of Employment Protection Mandates on Demographic Temporary Employment Patterns: International Microeconomic Evidence.” The Economic Journal, 117 (June), F333-F356.

Knight, J., and L. Song, and J. Huaibin. 1999. "Chinese Rural Migrants in Urban Enterprises: Three Perspectives,” J. Develop. Stud. 35, 3:73-104, February.

Kossoudji, S. 1989. “Immigrant Worker Assimilation: Is It a Labor Market Phenomenon?” Journal of Human Resources, Vol 24, No.3 Summer, pp 494-527

Kugler A., J.F. Jimeno, V. Hernanz. 2005. "Employment Consequences of Restrictive Permanent Contracts: Evidence from Spanish Labor Market Reforms.”, IZA working papers 657.

Lalonde, R., and R. Topel. 1992. "The Assimilation of Immigrants in the U.S. Labor Market," in George J. Borjas and Richard B. Freeman, editors, Immigration and the Work Force, Chicago: The University of Chicago Press, 1992, pp. 67-92.

Lubotsky, D., 2000. “Chutes or Ladders? A Longitudinal Analysis of Immigrant Earnings”, Princeton University Industrial Relations Section Working Paper No. 445, August.

Manacorda M., A. Manning and J. Wadsworth. 2006. "The Impact of Immigration on the Structure of Male Wages: Theory and Evidence from Britain.” IZA Discussion paper 2352. Bonn, Germany.

Manning, A. 2003. “Monopsony in Motion.” Princeton NJ: Princeton University Press.

Meng, Xin, 2000. “Labour Market Reform in China.” Cambridge: Cambridge Univ. Press.

Meng, X. and Zhang. 2001. “The Two-Tier Labor Market in Urban China: Occupational Segregation and Wage Differentials between Urban Residents and Rural Migrants in Shanghai1.” Journal of Comparative Economics 29, 485-504 (2001)

Ottaviano, G., and G. Peri. 2006. "Rethinking the Gains from Immigration on Wages.” NBER Working Paper \# 12497.

Peri, G., and C. Sparber. 2008. “Task Specialization, Immigration and Wages.” NBER Discussion Paper \# 02/08.

Pischke J-S. 1993. "Assimilation and the Earnings of Guestworkers in Germany.” MIT, Boston (unpublished). 
Ramos-Muñoz, B. 2007. “Comparación de las Magnitudes Estadísticas del Empleo según la Encuesta de Población Activa y la Muestra Continua de Vidas Laborales” mimeo presented in Jornadas de Usuarios de la Muestra Continua de Vidas Laborales, FEDEA (Madrid).

Ratha, D., and Shaw, W. 2007. "South-South Migration and Remittances." Washington: The World Bank Development Prospects Group.

Richardson, S., F. Robertson, and D. Ilsley. 2001. The Labour Force Experience of New Migrants.” National Institute of Labour Studies, Flinders University, Adelaide, Commonwealth of Australia, Canberra.

Richardson, S., L. Miller-Lewis, P. Ngo, and D. Ilsley. 2002. "The Settlement Experiences of New Migrants.” National Institute of Labour Studies, Flinders University, Adelaide, Commonwealth of Australia, Canberra.

Richmond, A., and W. Kalbach. 1980. "Factors in the Adjustment of Immigrants and Their Descendants.” Ottawa: Statistics Canada.

Schmidt, C. 1992. "Country-of-Origin Differences in the Earnings of German Immigrants.” Universität München Discussion Paper 92-29.

Segura, J.F., L. Toharia and S. Bentolila. 1991. “Análisis de la Contratación Temporal en España.” Centro de Publicaciones, Ministerio de Trabajo y Seguridad Social.

Thapa, P., and T. Gørgens. 2006. "Finding Employment After Migration: How Long Does it Take?”, in Deborah Cobb-Clark and Siew-Ean Khoo (eds.), Public Policy and Immigrant Settlement, Cheltenham: Edward Elgar.

Weiss, Y., R. Sauer, and M. Gotlibovski. 2003. "Immigration, Search and Loss of Skill." Journal of Labor Economics, 2003, vol. 21, no. 3.

Wu, H., and L. Zhou. 1996 "Rural to Urban Migration in China," Asia-Pacific Econ. Liter. 10, 2:54-67, November.

Xiang, B. 1996. "Mobility, Traditional Networking Marketisation and the Development of A 'Non-government' Controlled Space" (in Chinese), Paper presented at the International Conference on the Flow of Rural Labor in China, Beijing. 
Table 1

Incidence of Female Part-Time and Fixed-Term Employment, OECD 2008

\begin{tabular}{lc}
\hline & Incidence of female temporary employment \\
\hline Australia & $5.9 \%$ \\
Belgium & $9.7 \%$ \\
Germany & $14.9 \%$ \\
The Netherlands & $20 \%$ \\
Norway & $11.1 \%$ \\
Spain & $\mathbf{3 1 . 2} \%$ \\
The United Kingdom & $6 \%$ \\
The United States & $4.2 \%$ \\
\hline
\end{tabular}


Table 2

Descriptive Statistics

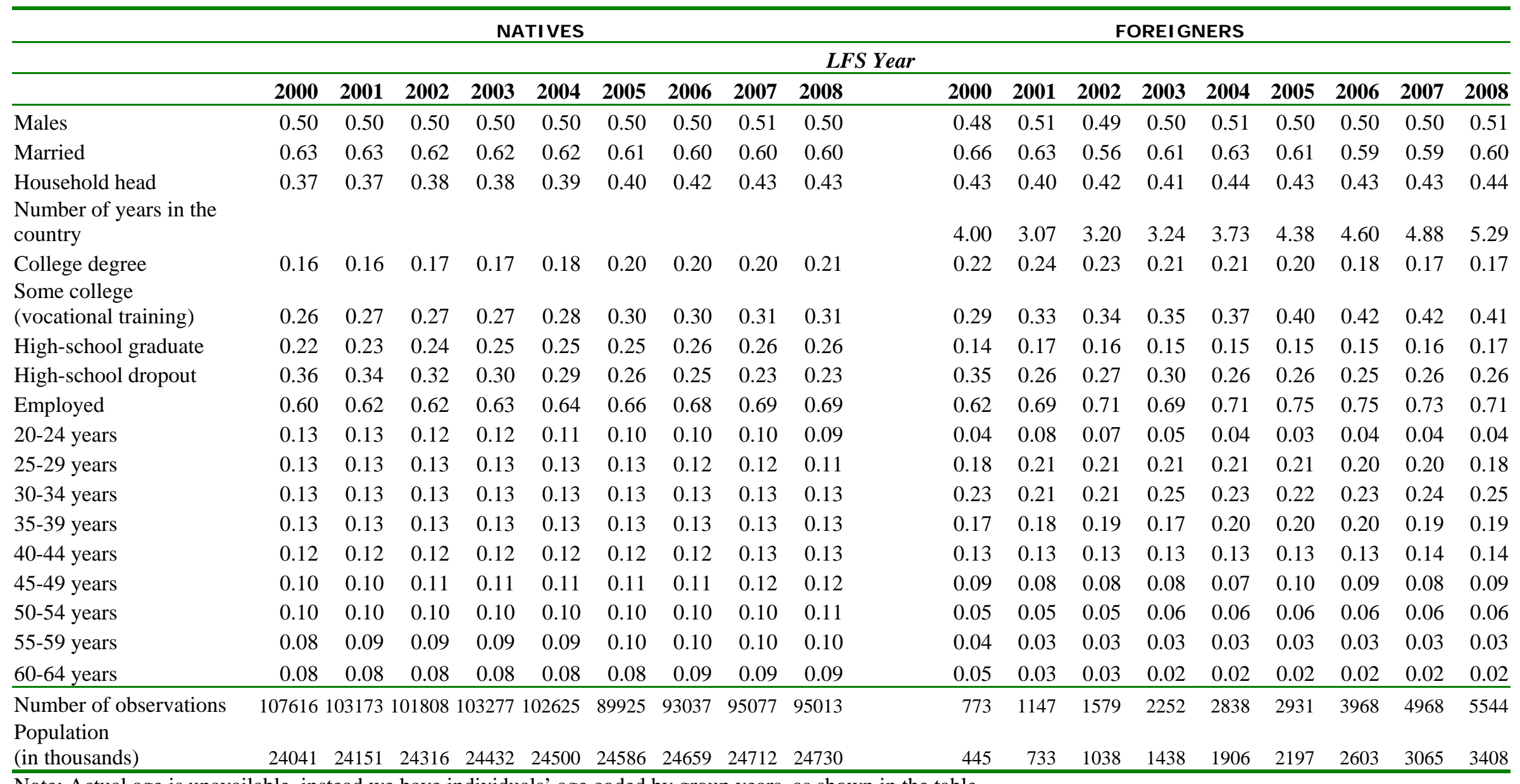

Note: Actual age is unavailable, instead we have individuals’ age coded by group years, as shown in the table. 
Table 2 (Continued)

Descriptive Statistics

\begin{tabular}{|c|c|c|c|c|c|c|c|c|c|}
\hline & \multicolumn{8}{|c|}{ LFS Year } & \multirow[b]{2}{*}{2008} \\
\hline & 2000 & 2001 & 2002 & 2003 & 2004 & 2005 & 2006 & 2007 & \\
\hline \multicolumn{10}{|l|}{ Continent of origin } \\
\hline From EU15 & 0.28 & 0.21 & 0.17 & 0.14 & 0.13 & 0.11 & 0.11 & 0.11 & 0.10 \\
\hline \multicolumn{10}{|l|}{ From Europe (excluding } \\
\hline EU15) & 0.08 & 0.14 & 0.16 & 0.20 & 0.20 & 0.23 & 0.21 & 0.23 & 0.24 \\
\hline From AFRICA & 0.27 & 0.21 & 0.16 & 0.18 & 0.16 & 0.15 & 0.17 & 0.17 & 0.17 \\
\hline From Latin America & 0.31 & 0.39 & 0.47 & 0.46 & 0.47 & 0.47 & 0.48 & 0.46 & 0.44 \\
\hline Other origin & 0.05 & 0.05 & 0.03 & 0.03 & 0.03 & 0.03 & 0.02 & 0.03 & 0.04 \\
\hline \multicolumn{10}{|l|}{ Year of arrival } \\
\hline $1990-94$ & 0.30 & 0.17 & 0.14 & 0.10 & 0.09 & 0.07 & 0.05 & 0.05 & 0.04 \\
\hline $1995-98$ & 0.40 & 0.24 & 0.19 & 0.14 & 0.09 & 0.10 & 0.09 & 0.07 & 0.05 \\
\hline 1999 & 0.12 & 0.14 & 0.11 & 0.08 & 0.08 & 0.08 & 0.04 & 0.04 & 0.04 \\
\hline 2000 & 0.18 & 0.18 & 0.17 & 0.16 & 0.15 & 0.15 & 0.13 & 0.09 & 0.09 \\
\hline 2001 & & 0.27 & 0.14 & 0.20 & 0.18 & 0.16 & 0.15 & 0.13 & 0.09 \\
\hline 2002 & & & 0.25 & 0.14 & 0.17 & 0.16 & 0.14 & 0.14 & 0.14 \\
\hline 2003 & & & & 0.18 & 0.12 & 0.13 & 0.13 & 0.11 & 0.10 \\
\hline 2004 & & & & & 0.11 & 0.11 & 0.10 & 0.11 & 0.11 \\
\hline 2005 & & & & & & 0.05 & 0.10 & 0.09 & 0.10 \\
\hline 2006 & & & & & & & 0.07 & 0.10 & 0.08 \\
\hline 2007 & & & & & & & & 0.07 & 0.10 \\
\hline 2008 & & & & & & & & & 0.06 \\
\hline Number of observations & 773 & 1147 & 1579 & 2252 & 2838 & 2931 & 3968 & 4968 & 5544 \\
\hline $\begin{array}{l}\text { Population } \\
\text { (in thousands) }\end{array}$ & 445 & 733 & 1038 & 1438 & 1906 & 2197 & 2603 & 3065 & 3408 \\
\hline
\end{tabular}


Table 3.A

Natives occupational distribution, by LFS

\begin{tabular}{lccccccccc}
\hline EPA year & $\mathbf{2 0 0 0}$ & $\mathbf{2 0 0 1}$ & $\mathbf{2 0 0 2}$ & $\mathbf{2 0 0 3}$ & $\mathbf{2 0 0 4}$ & $\mathbf{2 0 0 5}$ & $\mathbf{2 0 0 6}$ & $\mathbf{2 0 0 7}$ & $\mathbf{2 0 0 8}$ \\
\hline Not working & 0.40 & 0.38 & 0.38 & 0.37 & 0.36 & 0.34 & 0.32 & 0.31 & 0.31 \\
$\begin{array}{l}\text { Professional } \\
\text { Other White- }\end{array}$ & 0.18 & 0.19 & 0.19 & 0.20 & 0.21 & 0.22 & 0.23 & 0.25 & 0.25 \\
collar & 0.15 & 0.15 & 0.15 & 0.16 & 0.15 & 0.16 & 0.17 & 0.17 & 0.17 \\
Blue-collar & 0.20 & 0.20 & 0.20 & 0.20 & 0.20 & 0.20 & 0.20 & 0.19 & 0.19 \\
\hline Non Qualified & 0.08 & 0.08 & 0.08 & 0.08 & 0.08 & 0.08 & 0.08 & 0.08 & 0.08 \\
\hline
\end{tabular}

Table 3.B

Immigrants occupational distribution, by LFS

\begin{tabular}{|c|c|c|c|c|c|c|c|c|c|}
\hline EPA year & 2000 & 2001 & 2002 & 2003 & 2004 & 2005 & 2006 & 2007 & 2008 \\
\hline \multicolumn{10}{|c|}{ Year of arrival: 1990-1994 } \\
\hline Not working & 0.38 & 0.31 & 0.27 & 0.30 & 0.29 & 0.27 & 0.26 & 0.34 & 0.32 \\
\hline Professional & 0.20 & 0.23 & 0.23 & 0.21 & 0.22 & 0.24 & 0.15 & 0.22 & 0.23 \\
\hline Other White & 0.15 & 0.14 & 0.16 & 0.12 & 0.09 & 0.09 & 0.12 & 0.12 & 0.11 \\
\hline Blue Collar & 0.13 & 0.17 & 0.18 & 0.23 & 0.24 & 0.19 & 0.27 & 0.19 & 0.20 \\
\hline Non Qualified & 0.14 & 0.16 & 0.16 & 0.14 & 0.15 & 0.21 & 0.19 & 0.13 & 0.14 \\
\hline \multicolumn{10}{|c|}{ Year of arrival: 1995-1998 } \\
\hline Not working & 0.33 & 0.30 & 0.32 & 0.29 & 0.32 & 0.31 & 0.30 & 0.26 & 0.32 \\
\hline Professional & 0.10 & 0.17 & 0.14 & 0.09 & 0.20 & 0.17 & 0.15 & 0.16 & 0.14 \\
\hline Other White & 0.18 & 0.19 & 0.23 & 0.14 & 0.12 & 0.16 & 0.17 & 0.12 & 0.13 \\
\hline Blue Collar & 0.18 & 0.15 & 0.12 & 0.20 & 0.15 & 0.17 & 0.18 & 0.20 & 0.20 \\
\hline Non Qualified & 0.21 & 0.19 & 0.20 & 0.27 & 0.21 & 0.18 & 0.21 & 0.25 & 0.22 \\
\hline \multicolumn{10}{|c|}{ Year of arrival: 1999} \\
\hline Not working & 0.35 & 0.39 & 0.28 & 0.28 & 0.26 & 0.25 & 0.23 & 0.25 & 0.30 \\
\hline Professional & 0.18 & 0.11 & 0.05 & 0.07 & 0.09 & 0.08 & 0.08 & 0.08 & 0.14 \\
\hline Other White & 0.16 & 0.09 & 0.16 & 0.09 & 0.09 & 0.14 & 0.19 & 0.18 & 0.16 \\
\hline Blue Collar & 0.05 & 0.19 & 0.26 & 0.21 & 0.22 & 0.26 & 0.25 & 0.26 & 0.22 \\
\hline Non Qualified & 0.26 & 0.22 & 0.26 & 0.34 & 0.34 & 0.27 & 0.25 & 0.23 & 0.18 \\
\hline \multicolumn{10}{|c|}{ Year of arrival: 2000} \\
\hline Not working & 0.51 & 0.32 & 0.23 & 0.21 & 0.22 & 0.20 & 0.19 & 0.20 & 0.27 \\
\hline Professional & 0.09 & 0.07 & 0.05 & 0.11 & 0.07 & 0.04 & 0.06 & 0.08 & 0.08 \\
\hline Other White & 0.12 & 0.15 & 0.18 & 0.17 & 0.16 & 0.18 & 0.19 & 0.17 & 0.17 \\
\hline Blue Collar & 0.08 & 0.13 & 0.23 & 0.18 & 0.23 & 0.28 & 0.27 & 0.27 & 0.29 \\
\hline Non Qualified & 0.20 & 0.34 & 0.31 & 0.33 & 0.32 & 0.29 & 0.28 & 0.27 & 0.20 \\
\hline \multicolumn{10}{|c|}{ Year of arrival: 2001} \\
\hline Not working & & 0.26 & 0.27 & 0.25 & 0.20 & 0.19 & 0.19 & 0.24 & 0.24 \\
\hline Professional & & 0.14 & 0.09 & 0.08 & 0.07 & 0.07 & 0.08 & 0.07 & 0.07 \\
\hline Other White & & 0.12 & 0.14 & 0.16 & 0.15 & 0.22 & 0.17 & 0.16 & 0.16 \\
\hline Blue Collar & & 0.16 & 0.12 & 0.20 & 0.27 & 0.21 & 0.27 & 0.24 & 0.26 \\
\hline Non Qualified & & 0.32 & 0.39 & 0.32 & 0.32 & 0.31 & 0.28 & 0.29 & 0.26 \\
\hline \multicolumn{10}{|c|}{ Year of arrival: 2002} \\
\hline Not working & & & 0.35 & 0.30 & 0.27 & 0.25 & 0.23 & 0.18 & 0.23 \\
\hline Professional & & & 0.12 & 0.04 & 0.06 & 0.06 & 0.06 & 0.06 & 0.07 \\
\hline Other White & & & 0.16 & 0.16 & 0.16 & 0.16 & 0.17 & 0.18 & 0.15 \\
\hline Blue Collar & & & 0.11 & 0.17 & 0.18 & 0.19 & 0.22 & 0.27 & 0.27 \\
\hline Non Qualified & & & 0.26 & 0.33 & 0.32 & 0.33 & 0.32 & 0.32 & 0.27 \\
\hline
\end{tabular}


Table 3.B (Continued)

Immigrants occupational distribution, by LFS

\begin{tabular}{|c|c|c|c|c|c|c|c|c|c|}
\hline EPA year & 2000 & 2001 & 2002 & 2003 & 2004 & 2005 & 2006 & 2007 & 2008 \\
\hline \multicolumn{10}{|c|}{ Year of arrival: 2003} \\
\hline Not working & & & & 0.49 & 0.41 & 0.21 & 0.23 & 0.24 & 0.26 \\
\hline Professional & & & & 0.08 & 0.10 & 0.08 & 0.07 & 0.07 & 0.07 \\
\hline Other White & & & & 0.08 & 0.10 & 0.15 & 0.18 & 0.16 & 0.17 \\
\hline Blue Collar & & & & 0.12 & 0.15 & 0.17 & 0.20 & 0.24 & 0.25 \\
\hline Non Qualified & & & & 0.23 & 0.23 & 0.38 & 0.32 & 0.28 & 0.26 \\
\hline \multicolumn{10}{|c|}{ Year of arrival: 2004} \\
\hline Not working & & & & & 0.43 & 0.31 & 0.23 & 0.25 & 0.25 \\
\hline Professional & & & & & 0.13 & 0.10 & 0.07 & 0.07 & 0.07 \\
\hline Other White & & & & & 0.08 & 0.14 & 0.18 & 0.19 & 0.21 \\
\hline Blue Collar & & & & & 0.11 & 0.17 & 0.20 & 0.21 & 0.21 \\
\hline Non Qualified & & & & & 0.25 & 0.29 & 0.32 & 0.27 & 0.25 \\
\hline \multicolumn{10}{|c|}{ Year of arrival: 2005} \\
\hline Not working & & & & & & 0.37 & 0.32 & 0.30 & 0.26 \\
\hline Professional & & & & & & 0.07 & 0.07 & 0.06 & 0.05 \\
\hline Other White & & & & & & 0.13 & 0.15 & 0.19 & 0.19 \\
\hline Blue Collar & & & & & & 0.18 & 0.12 & 0.14 & 0.23 \\
\hline Non Qualified & & & & & & 0.25 & 0.34 & 0.31 & 0.26 \\
\hline \multicolumn{10}{|c|}{ Year of arrival: 2006} \\
\hline Not working & & & & & & & 0.42 & 0.34 & 0.35 \\
\hline Professional & & & & & & & 0.07 & 0.05 & 0.06 \\
\hline Other White & & & & & & & 0.13 & 0.14 & 0.13 \\
\hline Blue Collar & & & & & & & 0.16 & 0.16 & 0.22 \\
\hline Non Qualified & & & & & & & 0.23 & 0.31 & 0.24 \\
\hline \multicolumn{10}{|c|}{ Year of arrival: 2007} \\
\hline Not working & & & & & & & & 0.43 & 0.38 \\
\hline Professional & & & & & & & & 0.05 & 0.07 \\
\hline Other White & & & & & & & & 0.11 & 0.15 \\
\hline Blue Collar & & & & & & & & 0.14 & 0.16 \\
\hline Non Qualified & & & & & & & & 0.28 & 0.24 \\
\hline \multicolumn{10}{|c|}{ Year of arrival: 2008} \\
\hline Not working & & & & & & & & & 0.45 \\
\hline Professional & & & & & & & & & 0.06 \\
\hline Other White & & & & & & & & & 0.13 \\
\hline Blue Collar & & & & & & & & & 0.10 \\
\hline Non Qualified & & & & & & & & & 0.26 \\
\hline
\end{tabular}


Table 4. Types Under Analysis

\begin{tabular}{|c|c|}
\hline Types & Description \\
\hline Type 1 & $\begin{array}{l}\text { Male living in Madrid, aged } 35 \text { to } 39 \text { years old, currently married, without a high- } \\
\text { school degree. }\end{array}$ \\
\hline & For immigrants, that person is from Latin America and arrived in Spain in 2002. \\
\hline Type 2 & As type 1 but with a high-school degree. \\
\hline Type 3 & As type 1 but with vocational training or some college. \\
\hline Type 4 & As type 1 but with a university degree. \\
\hline Type 5 & As type 4 but comes from the EU15. \\
\hline Type 6 & As type 3 but comes from all European countries, excluding those from the EU15. \\
\hline Type 7 & As type 1 but comes from Africa. \\
\hline
\end{tabular}

Table 5. Incidence of Permanent Contract, by Education Level and Gender 2000-2008 LFS

\begin{tabular}{cccc}
\hline & High-school dropout & High-school graduate & University degree \\
\hline Natives & & Males & \\
Sample size & $67.61 \%$ & $74.39 \%$ & $81.68 \%$ \\
Immigrants & 86,330 & 174,137 & 59,401 \\
Sample size & $36 \%$ & $42.09 \%$ & $60.06 \%$ \\
& 4,104 & 7,331 & 1,851 \\
Natives & & Females & $72.04 \%$ \\
Sample size & $65.84 \%$ & $68.61 \%$ & 70,755 \\
Immigrants & 41,377 & 116,044 & $53.59 \%$ \\
Sample size & $49.16 \%$ & $48.86 \%$ & 1,957 \\
\hline
\end{tabular}

Note: Only wage and salary workers. 
Table 6. Probability of Working with a Permanent Contract, 2000-2008 LFS

\begin{tabular}{|c|c|c|c|}
\hline & High-school dropout & High-school graduate & University degree \\
\hline & \multicolumn{3}{|c|}{ Wage and Salary Male Workers } \\
\hline \multirow[t]{2}{*}{ Years since arrival } & $0.009 * *$ & $0.004^{*}$ & 0.002 \\
\hline & $(0.004)$ & $(0.002)$ & $(0.003)$ \\
\hline Years since arrival & $-0.000 * *$ & $-0.000 * *$ & $-7.17 e-05$ \\
\hline squared & $(9.85 \mathrm{e}-05)$ & $(6.17 \mathrm{e}-05)$ & $(6.60 \mathrm{e}-05)$ \\
\hline \multirow[t]{2}{*}{ Immigrant dummy } & $-0.439 * * *$ & $-0.455^{* * *}$ & $-0.345^{* * *}$ \\
\hline & $(0.030)$ & $(0.020)$ & $(0.041)$ \\
\hline Arrival cohort 2000- & $0.086 * * *$ & $0.073 * * *$ & 0.016 \\
\hline 2004 & $(0.033)$ & $(0.021)$ & $(0.026)$ \\
\hline Arrival cohort 1995- & $0.095 * *$ & $0.094 * * *$ & 0.075 \\
\hline 1999 & $(0.039)$ & $(0.020)$ & $(0.061)$ \\
\hline Arrival cohort 1990- & 0.122 & 0.084 & $0.078 *$ \\
\hline 1994 & $(0.076)$ & $(0.056)$ & $(0.046)$ \\
\hline Arrival cohort 1989 & 0.114 & 0.078 & \\
\hline and earlier & $(0.096)$ & $(0.074)$ & \\
\hline \multirow[t]{2}{*}{ Sample size } & 89,670 & 180,324 & 60,848 \\
\hline & \multicolumn{3}{|c|}{ Wage and Salary Female Workers } \\
\hline \multirow[t]{2}{*}{ Years since arrival } & $0.009 *$ & $0.004^{*}$ & $-0.006^{*}$ \\
\hline & $(0.005)$ & $(0.003)$ & $(0.004)$ \\
\hline Years since arrival & -0.000 & -0.000 & 0.000 \\
\hline squared & $(0.000)$ & $(7.05 \mathrm{e}-05)$ & $(0.000)$ \\
\hline \multirow[t]{2}{*}{ Immigrant dummy } & $-0.228 * * *$ & $-0.304 * * *$ & $-0.253 * * *$ \\
\hline & $(0.047)$ & $(0.020)$ & $(0.039)$ \\
\hline Arrival cohort 2000- & 0.029 & $0.035^{*}$ & -0.025 \\
\hline 2004 & $(0.060)$ & $(0.021)$ & $(0.055)$ \\
\hline Arrival cohort 1995- & 0.070 & $0.057 * *$ & -0.078 \\
\hline 1999 & $(0.053)$ & $(0.027)$ & $(0.192)$ \\
\hline Arrival cohort 1990- & $0.285^{* * *}$ & -0.010 & -0.154 \\
\hline 1994 & $(0.053)$ & $(0.090)$ & $(0.164)$ \\
\hline Arrival cohort 1989 & $0.322 * * *$ & 0.107 & \\
\hline and earlier & $(0.038)$ & $(0.112)$ & \\
\hline Sample size & 42,986 & 121,363 & 72,077 \\
\hline
\end{tabular}

Note: Marginal effects. Robust standard errors in parentheses. In addition, regressions include age dummies, LFS-year dummies, region dummies, and province unemployment rate. See Appendix Tables A.8 and A.9 for complete list of coefficients. In all cases, we use sampling weights. ${ }^{* * *} p<0.01, * *$ $\mathrm{p}<0.05, * \mathrm{p}<0.1$ 
Table 7. Wage Equation Estimations at Percentile 50 Longitudinal 1979-2005 CSWH

\begin{tabular}{|c|c|c|c|c|}
\hline & $\begin{array}{c}\text { High-school } \\
\text { dropout }\end{array}$ & $\begin{array}{c}\text { High-school } \\
\text { graduate }\end{array}$ & University degree & $\begin{array}{c}\text { Whole sample } \\
\text { Izquierdo et al., } \\
2009\end{array}$ \\
\hline \multicolumn{5}{|c|}{ Males } \\
\hline Years since & $0.101 * * *$ & $0.102 * * *$ & $0.033 * * *$ & $0.086 * * *$ \\
\hline Years since & $0.113 * * *$ & $0.110 * * *$ & $0.043 * * *$ & $0.127 * * *$ \\
\hline arrival, 3-4 & $(0.010)$ & $(0.017)$ & $(0.005)$ & $(0.006)$ \\
\hline Years since & $0.072 * * *$ & $0.094 * * *$ & $0.032 * * *$ & $0.143 * * *$ \\
\hline arrival, 5-6 & $(0.013)$ & $(0.023)$ & $(0.008)$ & $(0.009)$ \\
\hline Years since & $0.049 * * *$ & $0.091 * * *$ & $0.034 * * *$ & $0.169 * * *$ \\
\hline arrival, 7-8 & $(0.015)$ & $(0.029)$ & $(0.011)$ & $(0.012)$ \\
\hline Years since & $0.074 * * *$ & $0.111 * * *$ & $0.042 * * *$ & $0.192 * * *$ \\
\hline arrival, 9-10 & $(0.017)$ & $(0.033)$ & $(0.013)$ & $(0.015)$ \\
\hline Years since & $0.133 * * *$ & $0.088 * * *$ & $0.047 * * *$ & $0.193 * * *$ \\
\hline arrival, 11-12 & $(0.019)$ & $(0.034)$ & $(0.015)$ & $(0.018)$ \\
\hline Years since & $0.191 * * *$ & $0.084 * * *$ & $0.041 * * *$ & $0.201 * * *$ \\
\hline arrival, 13+ & $(0.020)$ & $(0.041)$ & $(0.018)$ & $(0.022)$ \\
\hline \multicolumn{5}{|l|}{ Immigrant } \\
\hline dummy & $0.356 * * *$ & $-0.420 * * *$ & $-0.283 * * *$ & $-0.395 * * *$ \\
\hline (non-UE15) & $(0.023)$ & $(0.063)$ & $(0.032)$ & $(0.019)$ \\
\hline Arrival cohort & $-0.407 * * *$ & 0.001 & 0.040 & $-0.100 * * *$ \\
\hline $1983-1985$ & $(0.028)$ & $(0.090)$ & $(0.050)$ & $(0.040)$ \\
\hline Arrival cohort & $-0.241 * * *$ & $0.215 * * *$ & $0.137 * * *$ & -0.012 \\
\hline $1986-1990$ & $(0.023)$ & $(0.066)$ & $(0.035)$ & $(0.022)$ \\
\hline Arrival cohort & $-0.361 * * *$ & $0.198 * * *$ & $0.194 * * *$ & -0.002 \\
\hline 1991-1995 & $(0.021)$ & $(0.061)$ & $(0.032)$ & $(0.013)$ \\
\hline Arrival cohort & $-0.457 * * *$ & $0.222 * * *$ & $0.256 * * *$ & $0.080 * * *$ \\
\hline $1996-2000$ & $(0.022)$ & $(0.062)$ & $(0.032)$ & $(0.013)$ \\
\hline Arrival cohort & $-0.425 * * *$ & $0.242 * * *$ & $0.253 * * *$ & $0.058 * * *$ \\
\hline 2001-2005 & $(0.022)$ & $(0.062)$ & $(0.032)$ & $(0.013)$ \\
\hline Sample size & 938,180 & 915,107 & $1,328,518$ & \\
\hline
\end{tabular}

Note: Dependent variable: logarithm of daily wages. Regressions are estimated pooling natives and immigrants coming from countries outside the EU-15. In addition, regressions include experience in Spain and abroad, the NAIRU (HP filter on the original unemployment) and region dummies. See Appendix Table A.10 for complete list of coefficients. Restricting time effects to certain macroeconomic variables has been widely used in the literature (see Beaudry and Lemieux, 1999). $\quad * * * \mathrm{p}<0.01, * *$ $\mathrm{p}<0.05, * \mathrm{p}<0.1$ The analysis is done with the same sample as in Izquierdo et al., 2009. 
Figure 1.A : Differences in Occupational Predicted Probabilities between Immigrants and Natives, by Time in Spain Males by Level of Schooling
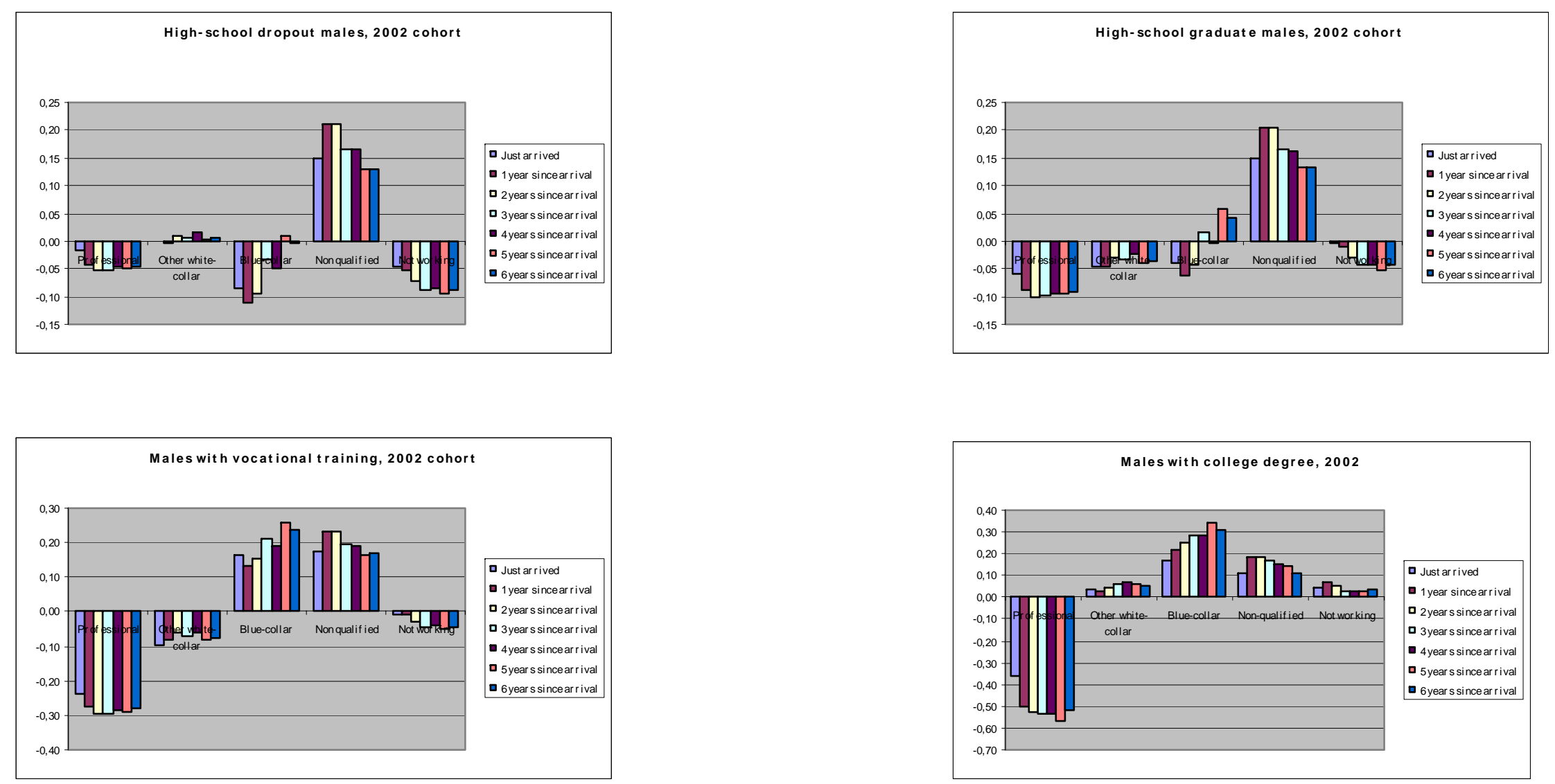
Figure 1.B : Differences in Occupational Predicted Probabilities between Immigrants and Natives, by Time in Spain Females by Level of Schooling
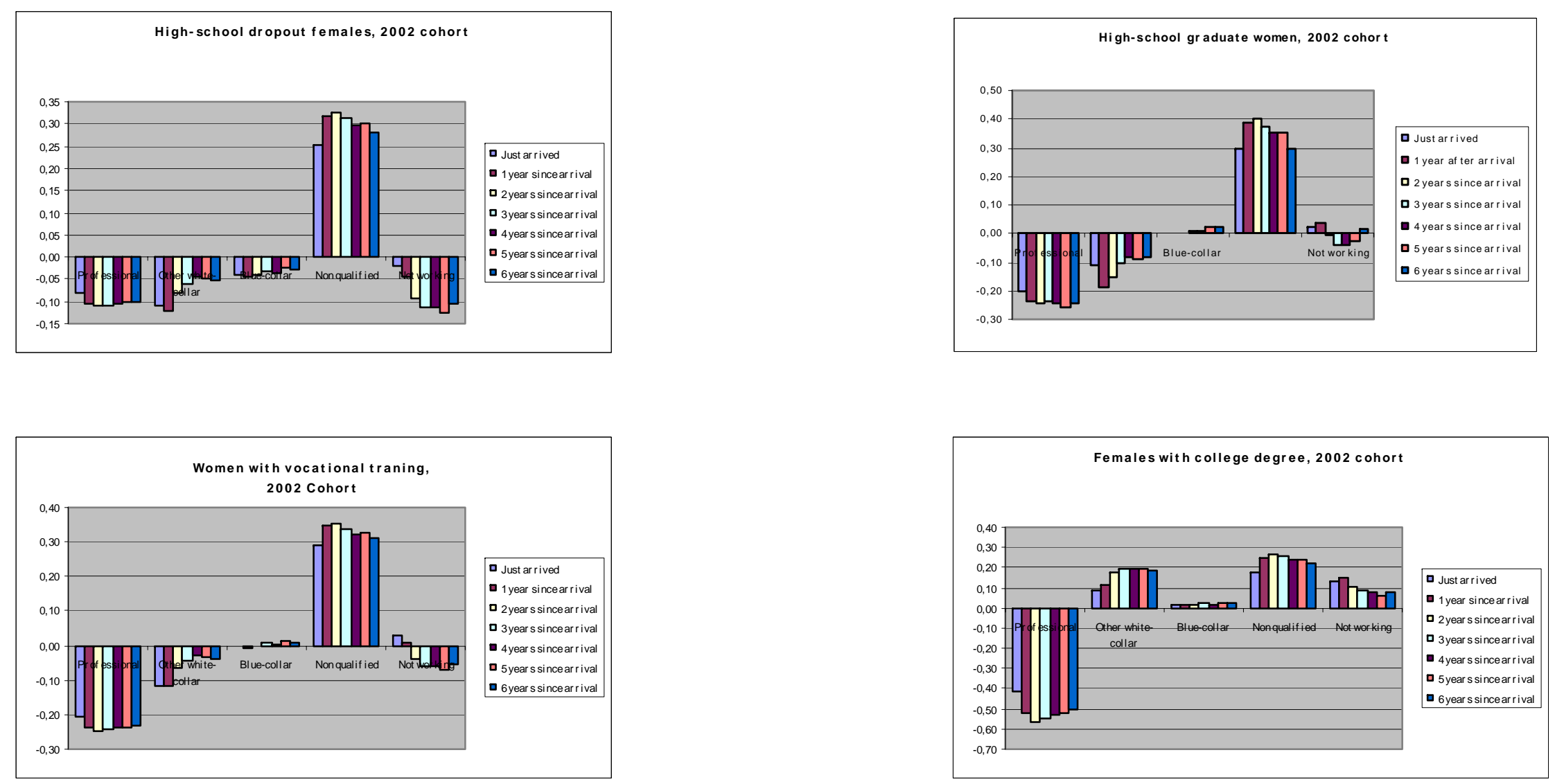
Figure 1.C : Differences in Occupational Predicted Probabilities between Immigrants and Natives, by Time in Spain Males by Continent of Origin
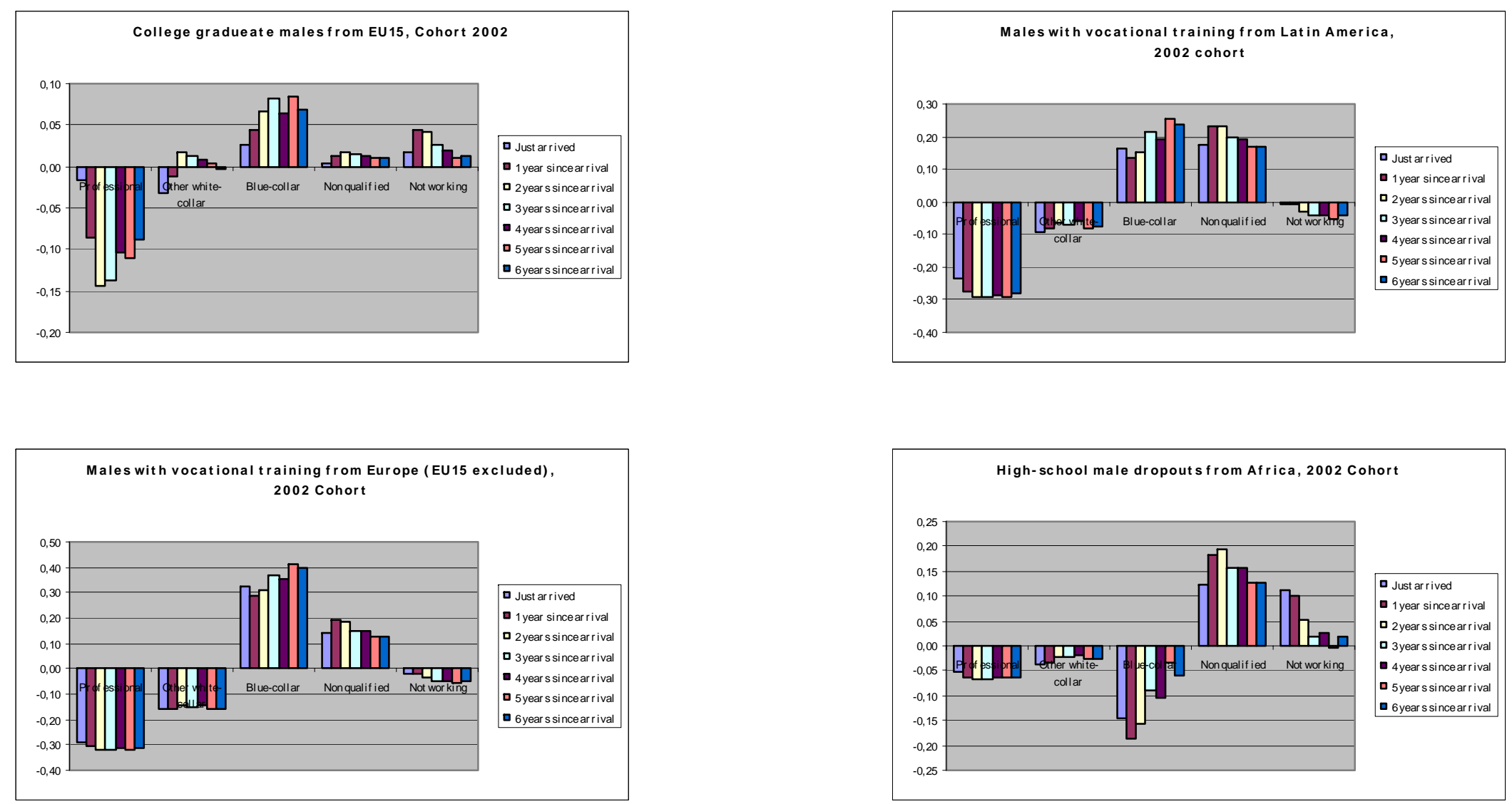
Figure 1.D : Differences in Occupational Predicted Probabilities between Immigrants and Natives, by Time in Spain Females by Continent of Origin
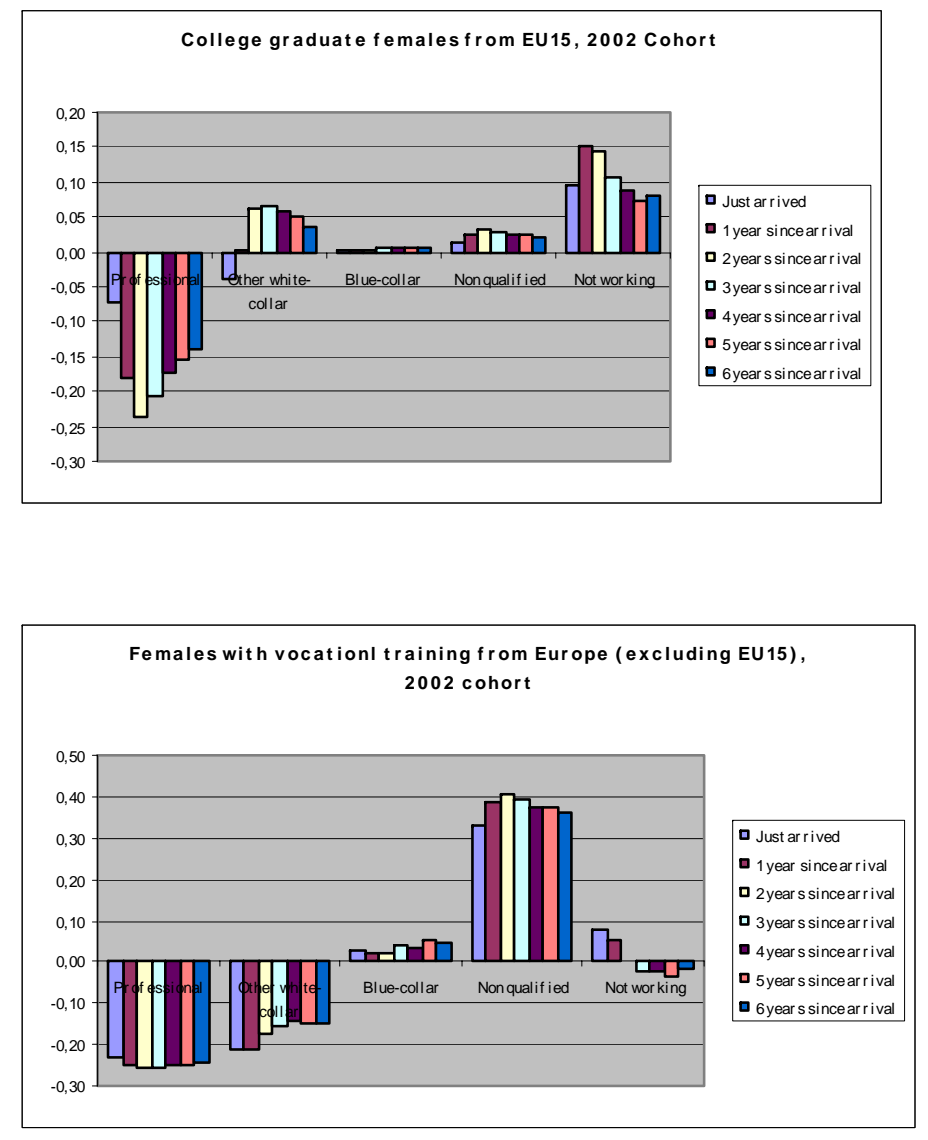
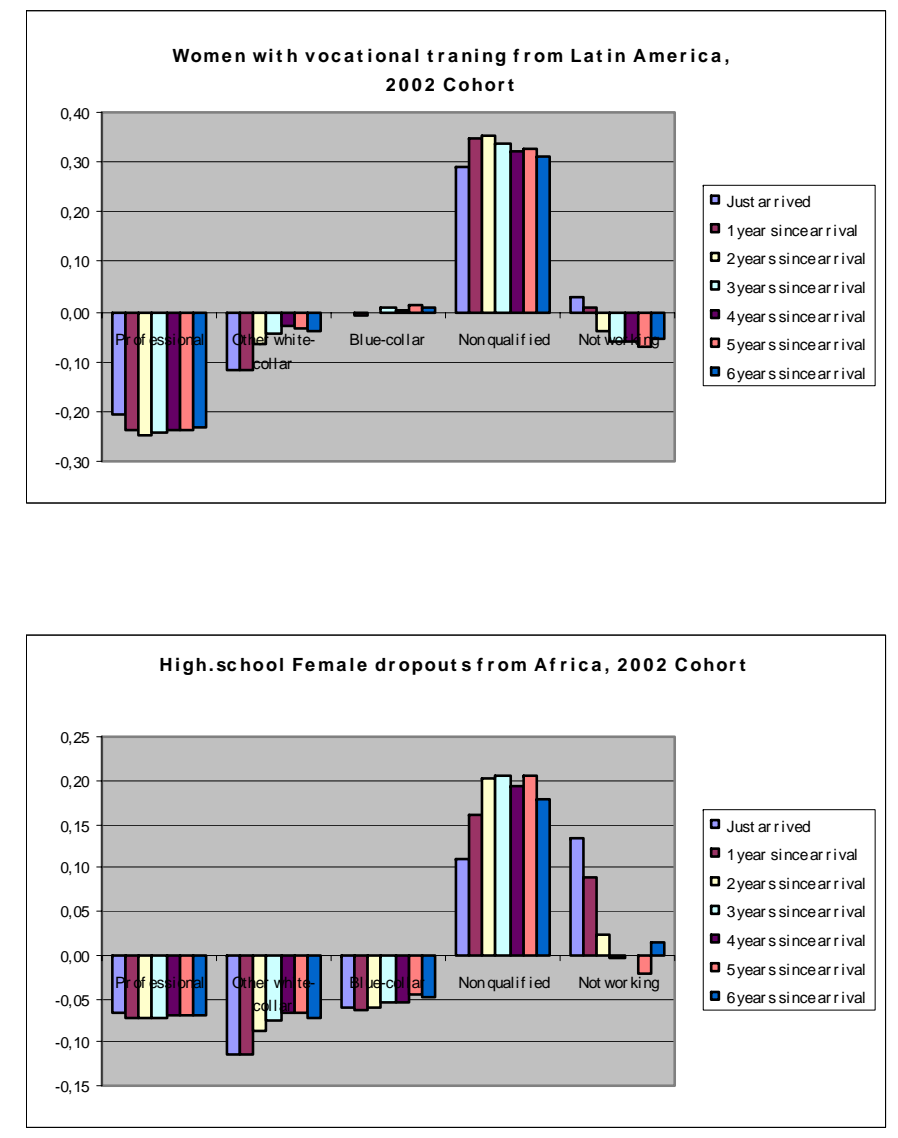
Figure 2.A : Change in Occupational Predicted Probabilities with Time in Spain (Net of Changes Observed in Native Population) Males by Level of Schooling
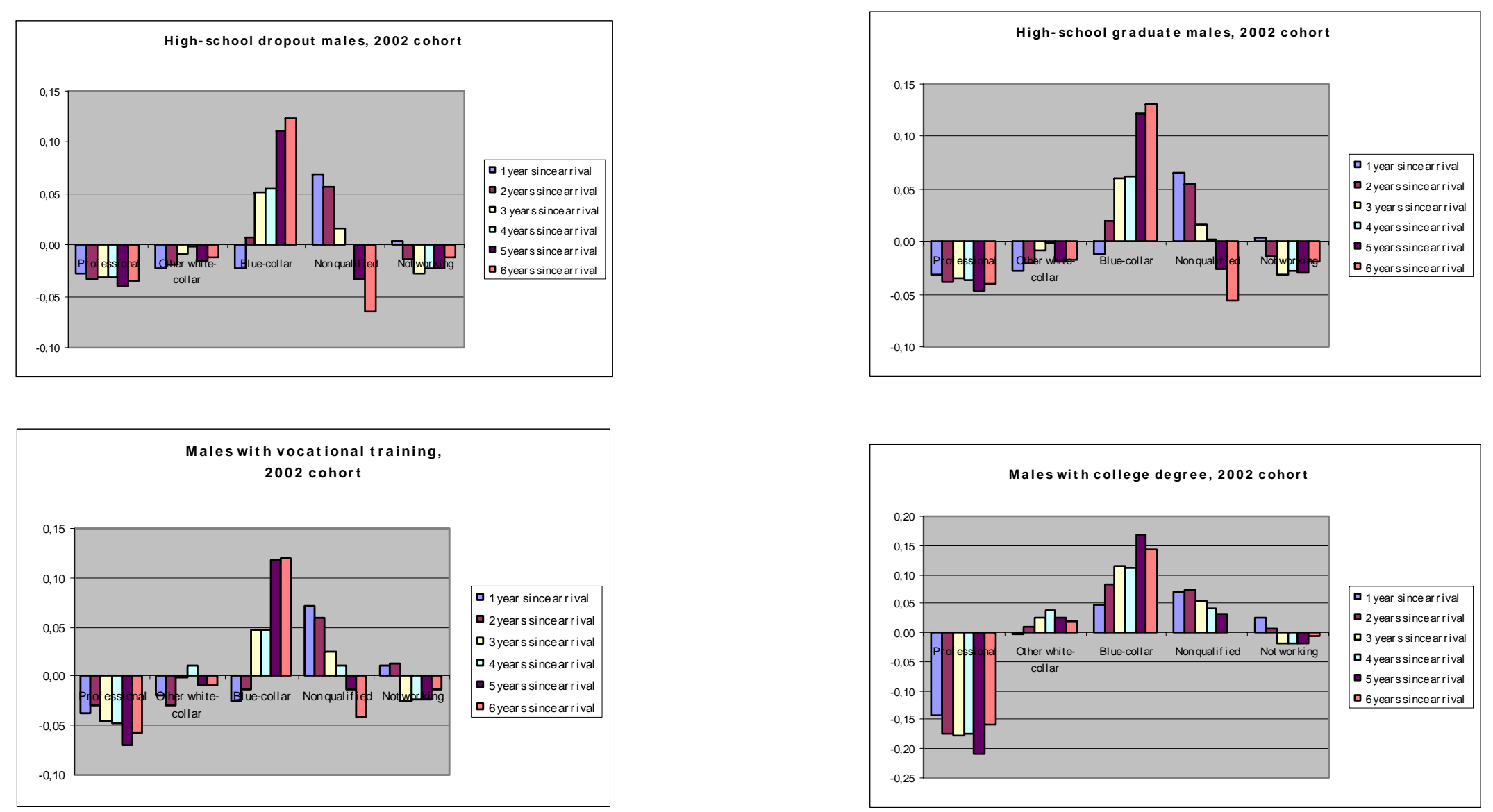
Figure 2.B : Change in Occupational Predicted Probabilities with Time in Spain (Net of Changes Observed in Native Population) Females by Level of Schooling
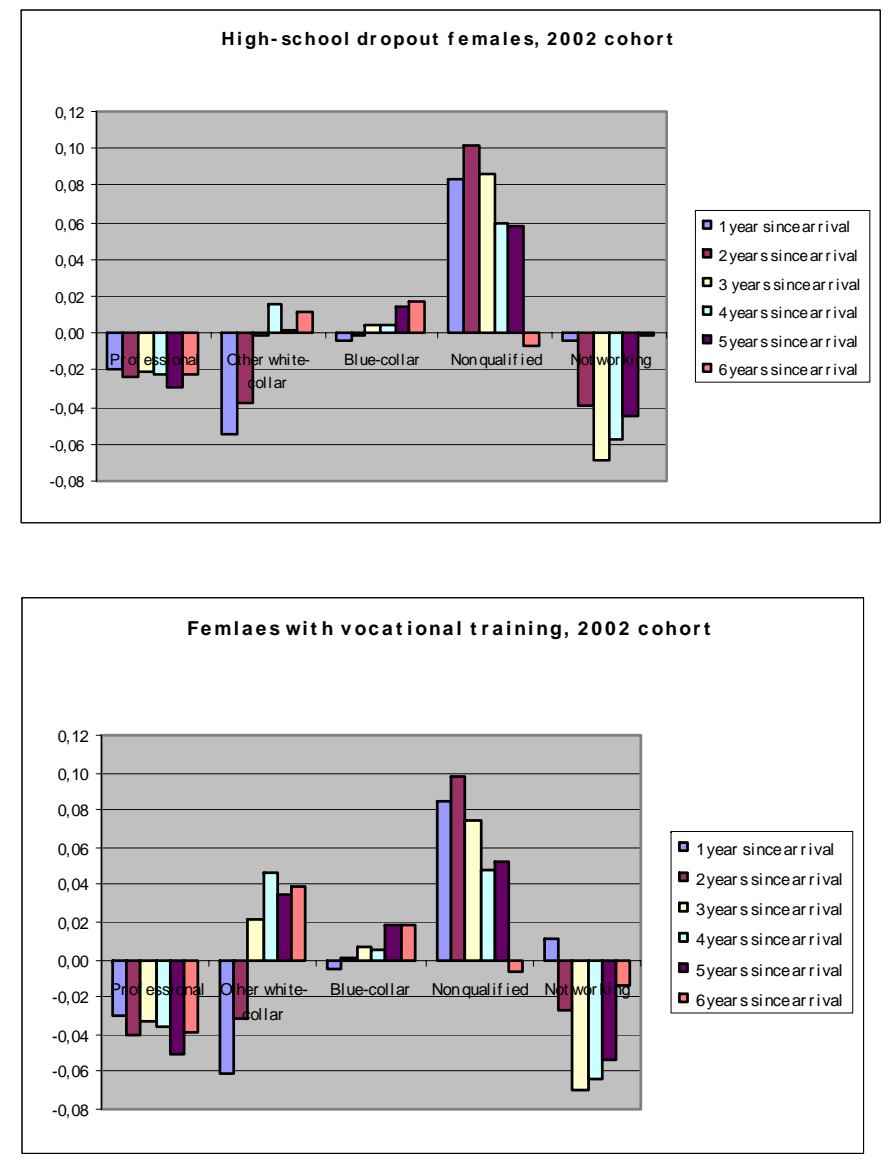
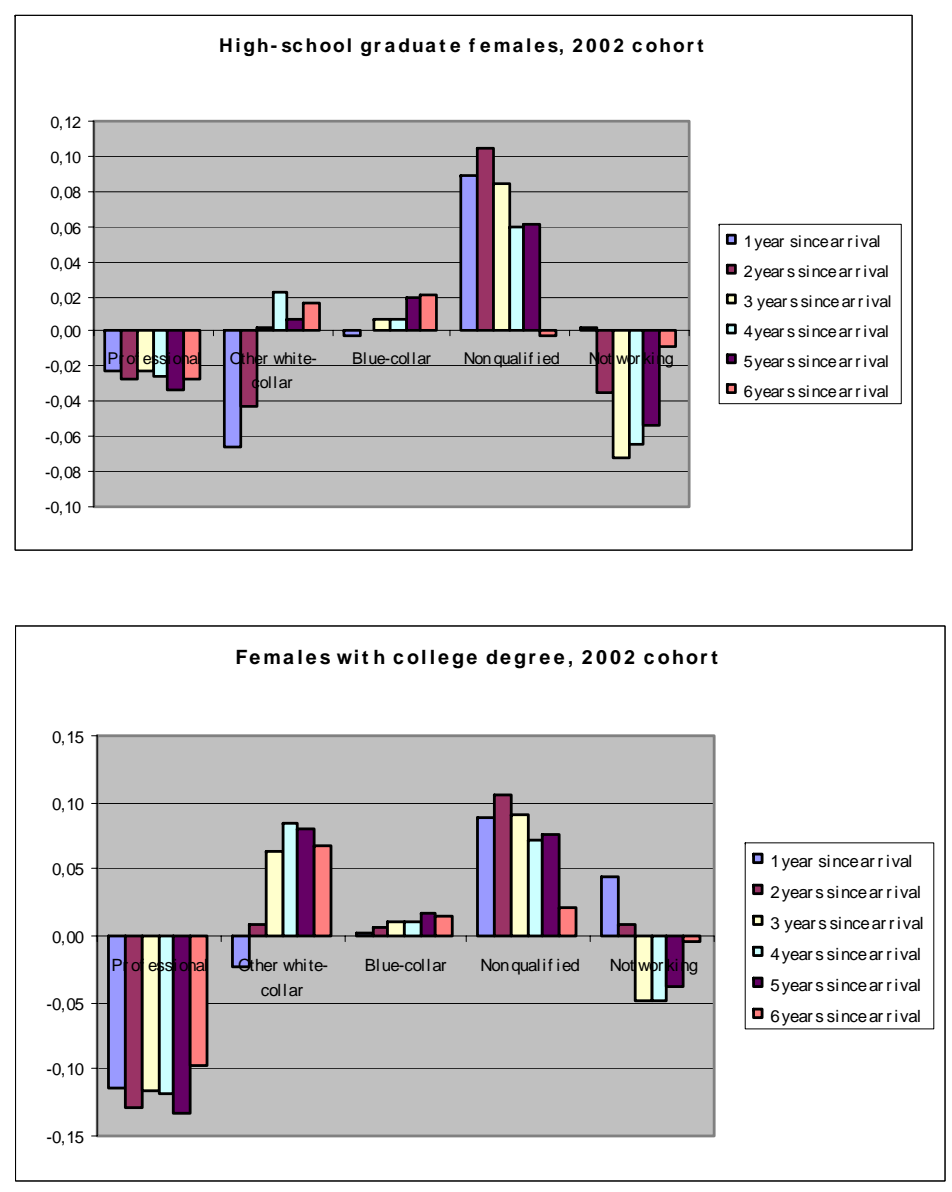
Figure 2.C : Change in Occupational Predicted Probabilities with Time in Spain (Net of Changes Observed in Native Population) Males by Continent of Origin
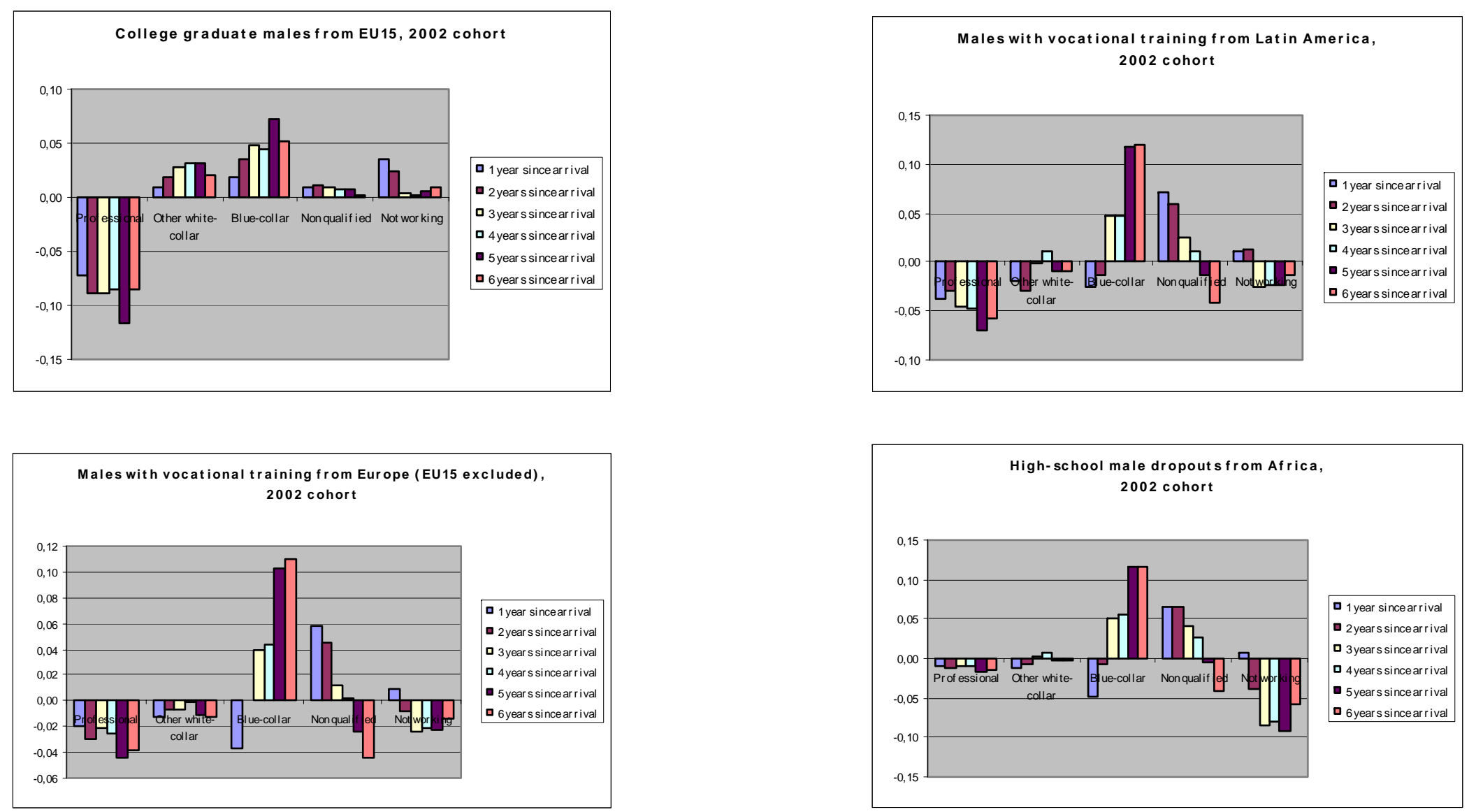
Figure 2.D : Change in Occupational Predicted Probabilities with Time in Spain (Net of Changes Observed in Native Population) Females by Continent of Origin
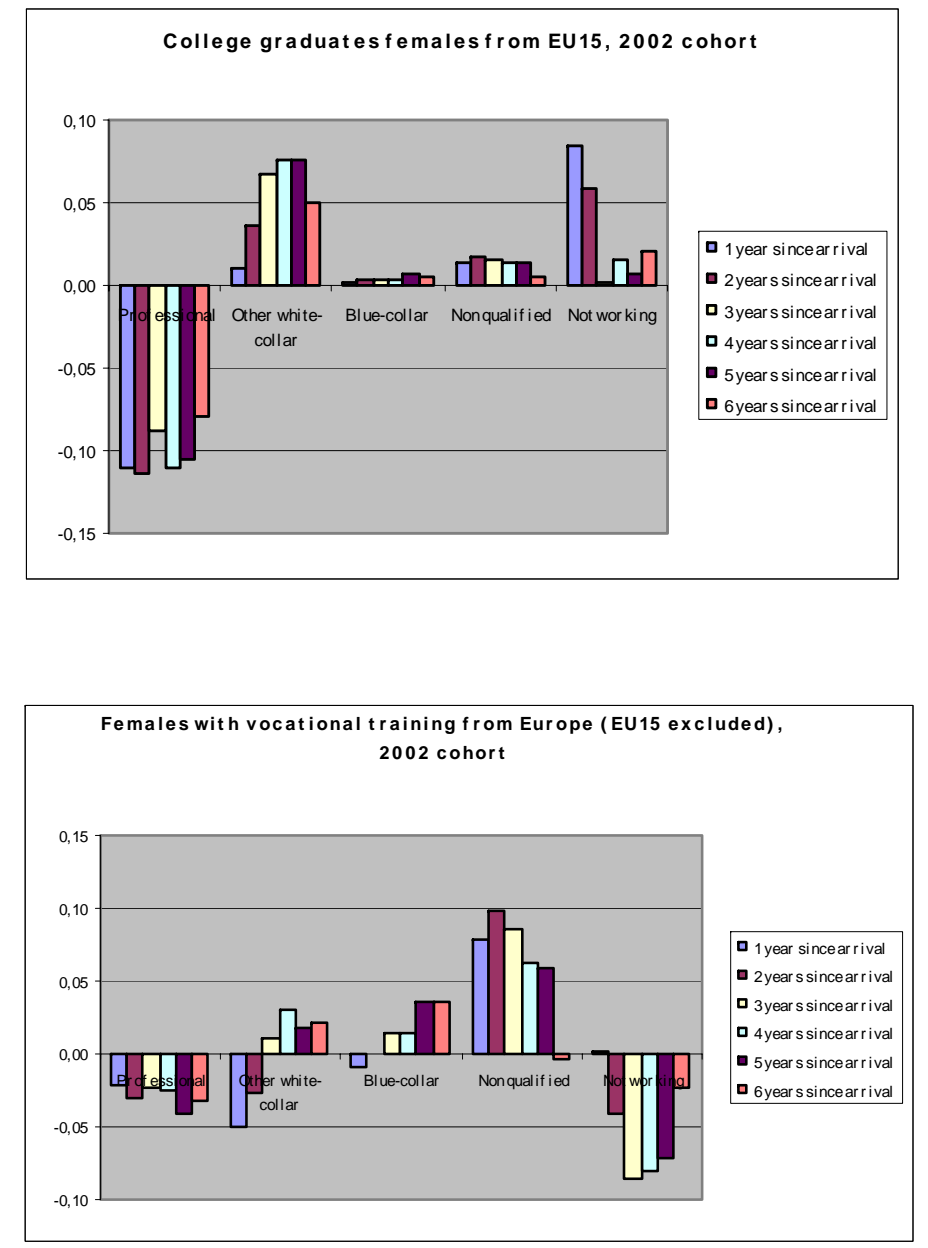
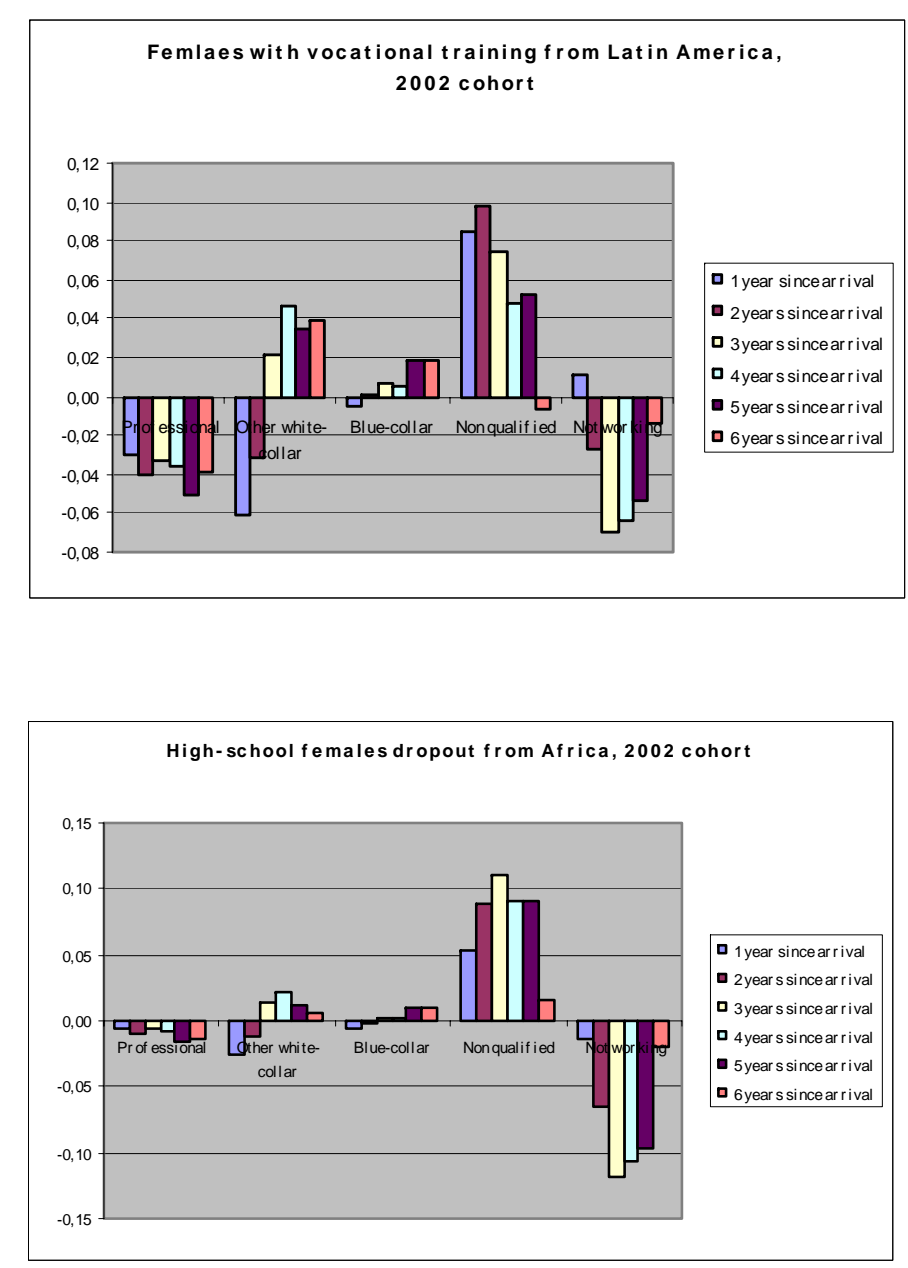


\section{APPENDIX TABLES}

(Not necessarily for publication) 
Table A.1.

Population Sizes for Entering Cohorts at Different LFS

\begin{tabular}{|c|c|c|c|c|c|c|c|c|c|}
\hline Cohort & LFS 2000 & LFS 2001 & LFS 2002 & LFS 2003 & $\begin{array}{l}\text { LFS year } \\
\text { LFS } 2004\end{array}$ & LFS 2005 & LFS 2006 & LFS 2007 & LFS 2008 \\
\hline 1990-94 & 131,932 & 125,443 & 141,266 & 140,285 & 178,210 & 147,099 & 131,297 & 138,977 & 152,294 \\
\hline 1995-99 & 232,023 & 277,238 & 317,573 & 323,659 & 333,368 & 391,746 & 345,653 & 344,972 & 310,011 \\
\hline 2000 & 80,703 & 132,422 & 180,063 & 230,401 & 279,139 & 339,567 & 333,772 & 280,714 & 290,766 \\
\hline 2001 & -- & 197,864 & 142,194 & 284,913 & 341,309 & 341,646 & 382,892 & 395,326 & 302,514 \\
\hline 2002 & -- & -- & 257,123 & 200,531 & 323,700 & 341,128 & 366,689 & 431,619 & 470,337 \\
\hline 2003 & -- & -- & -- & 257,927 & 235,628 & 276,811 & 327,531 & 324,842 & 352,145 \\
\hline 2004 & -- & -- & -- & -- & 215,130 & 239,124 & 265,718 & 347,511 & 379,375 \\
\hline 2005 & -- & -- & -- & -- & -- & 120,128 & 258,347 & 264,310 & 325,424 \\
\hline 2006 & -- & -- & -- & -- & -- & -- & 191,264 & 307,070 & 271,440 \\
\hline 2007 & -- & -- & -- & -- & -- & -- & -- & 229,317 & 354,462 \\
\hline 2008 & -- & -- & -- & -- & -- & -- & -- & -- & 198,944 \\
\hline
\end{tabular}


Table A.2.

Descriptive Statistics for 2002 Cohort of Immigrants across Different LFS

\begin{tabular}{lrrrrrrr}
\hline & $\mathbf{2 0 0 2}$ & $\mathbf{2 0 0 3}$ & $\mathbf{2 0 0 4}$ & $\mathbf{2 0 0 5}$ & $\mathbf{2 0 0 6}$ & $\mathbf{2 0 0 7}$ & $\mathbf{2 0 0 8}$ \\
& 0.51 & 0.51 & 0.50 & 0.48 & 0.49 & 0.48 & 0.52 \\
Males & 0.52 & 0.52 & 0.65 & 0.61 & 0.59 & 0.59 & 0.61 \\
Married & 0.34 & 0.34 & 0.37 & 0.41 & 0.46 & 0.46 & 0.49 \\
Household head & 0.18 & 0.18 & 0.20 & 0.18 & 0.17 & 0.15 & 0.15 \\
College degree & & & & & & & \\
Some college & 0.40 & 0.40 & 0.40 & 0.42 & 0.45 & 0.48 & 0.46 \\
(vocational training) & 0.14 & 0.14 & 0.15 & 0.16 & 0.16 & 0.16 & 0.16 \\
High-school graduate & 0.28 & 0.28 & 0.25 & 0.24 & 0.23 & 0.21 & 0.24 \\
High-school dropout & 0.70 & 0.70 & 0.73 & 0.75 & 0.77 & 0.82 & 0.77 \\
Employed & 0.15 & 0.15 & 0.14 & 0.12 & 0.12 & 0.12 & 0.11 \\
From EU15 & & & & & & & \\
From Europe & 0.21 & 0.21 & 0.23 & 0.24 & 0.22 & 0.23 & 0.22 \\
(excluding EU15) & 0.17 & 0.17 & 0.16 & 0.15 & 0.16 & 0.19 & 0.20 \\
From AFRICA & 0.44 & 0.44 & 0.44 & 0.46 & 0.47 & 0.45 & 0.45 \\
From Latin America & 0.03 & 0.03 & 0.02 & 0.03 & 0.02 & 0.01 & 0.02 \\
Other origin & & & & & & & \\
\hline
\end{tabular}


Table A.3

Educational Attainment of Natives and Immigrants in the 1999-2008 LFS

\begin{tabular}{|c|c|c|c|c|c|c|}
\hline \multirow[b]{3}{*}{ Highest education } & \multirow{3}{*}{ All } & \multirow{3}{*}{ Natives } & \multicolumn{4}{|c|}{ Immigrants } \\
\hline & & & \multirow[t]{2}{*}{ All } & \multicolumn{3}{|l|}{ In Spain } \\
\hline & & & & Since 1990-1995 & Since 1996-2001 & Since 2002 \\
\hline High-school dropouts & 29.02 & 29.19 & 26.59 & 33.12 & 18.83 & 24.28 \\
\hline High-school graduates & 24.08 & 24.67 & 15.64 & 13.34 & 37.65 & 15.91 \\
\hline $\begin{array}{l}\text { Some college (including } \\
\text { vocational training) }\end{array}$ & 28.89 & 28.19 & 38.77 & 30.14 & 15.89 & 41.61 \\
\hline College degree or more & 18.02 & 17.95 & 18.99 & 23.40 & 27.63 & 18.2 \\
\hline Sample sizes & $1.0 \mathrm{e}+06$ & $1.0 \mathrm{e}+06$ & $2.7 e+04$ & 2862 & $1.1 \mathrm{e}+04$ & $1.3 e+04$ \\
\hline \multicolumn{7}{|c|}{ Men } \\
\hline High-school dropouts & 28.06 & 28.02 & 28.71 & 36.68 & 29.85 & 25.60 \\
\hline High-school graduates & 25.40 & 26.08 & 15.69 & 14.30 & 15.85 & 15.89 \\
\hline $\begin{array}{l}\text { Some college (including } \\
\text { vocational training) }\end{array}$ & 29.81 & 29.21 & 38.27 & 26.98 & 37.02 & 42.32 \\
\hline College degree or more & 16.73 & 16.69 & 17.32 & 22.05 & 17.28 & 16.19 \\
\hline Sample sizes & $5.1 \mathrm{e}+05$ & $4.9 e+05$ & $1.3 e+04$ & 1581 & 5595 & 5749 \\
\hline \multicolumn{7}{|c|}{ Women } \\
\hline High-school dropouts & 29.98 & 30.36 & 24.45 & 28.67 & 25.19 & 23.09 \\
\hline High-school graduates & 22.76 & 23.26 & 15.59 & 12.13 & 15.94 & 15.93 \\
\hline $\begin{array}{l}\text { Some college (including } \\
\text { vocational training) }\end{array}$ & 27.96 & 27.17 & 39.28 & 34.09 & 38.34 & 40.96 \\
\hline College degree or more & 19.31 & 19.21 & 20.68 & 25.10 & 20.52 & 20.01 \\
\hline Sample sizes & $5.3 e+05$ & $5.1 \mathrm{e}+05$ & $1.4 \mathrm{e}+04$ & 1281 & 5421 & 6982 \\
\hline
\end{tabular}


Table A.4

Educational Attainment of Natives and Immigrants in the 1999-2008 LFS, by Origin

\begin{tabular}{|c|c|c|c|c|}
\hline \multirow{5}{*}{ Highest education } & \multicolumn{4}{|c|}{ EU15 } \\
\hline & \multirow[t]{4}{*}{ All } & \multicolumn{3}{|c|}{ In Spain } \\
\hline & & Since & Since & Since \\
\hline & & $1990-$ & 1996- & 2002 \\
\hline & & & 2001 & \\
\hline High-school dropouts & .1086 & .123 & .1016 & .1072 \\
\hline High-school graduates & .1539 & .1673 & .1518 & .1476 \\
\hline Some college (including vocational training) & .3519 & .3486 & .3408 & .3664 \\
\hline College degree or more & .3856 & .3611 & .4059 & .3788 \\
\hline \multirow{2}{*}{ Sample sizes } & 3287 & 878 & 1328 & 1081 \\
\hline & \multicolumn{4}{|c|}{ Latin America } \\
\hline High-school dropouts & .2214 & .2208 & .2186 & .2238 \\
\hline High-school graduates & .1807 & .1406 & .1858 & .1799 \\
\hline Some college (including vocational training) & .4275 & .3835 & .4331 & .4266 \\
\hline College degree or more & .1703 & .2552 & .1624 & .1697 \\
\hline \multirow[t]{2}{*}{ Sample sizes } & $1.2 \mathrm{e}+04$ & 558 & 5069 & 6217 \\
\hline & \multicolumn{4}{|c|}{ Eastern Europe } \\
\hline High-school dropouts & .1528 & .0735 & .1345 & .1701 \\
\hline High-school graduates & .1228 & .0585 & .1092 & .1362 \\
\hline Some college (including vocational training) & .5251 & .5749 & .5173 & .5258 \\
\hline College degree or more & .1993 & .2931 & .239 & .1679 \\
\hline \multirow[t]{2}{*}{ Sample sizes } & 5794 & 245 & 2003 & 3546 \\
\hline & \multicolumn{4}{|c|}{ Africa } \\
\hline High-school dropouts & 6213 & .6723 & 6352 & .5718 \\
\hline High-school graduates & .1373 & .1118 & .1498 & .1339 \\
\hline Some college (including vocational training) & .1725 & .1555 & .1523 & .2114 \\
\hline College degree or more & .069 & .0605 & .0628 & .0829 \\
\hline Sample sizes & 4911 & 984 & 2292 & 1635 \\
\hline
\end{tabular}


Table A.5. Multinomial Logit, Relative Risk Ratios, LFS 2000-2008

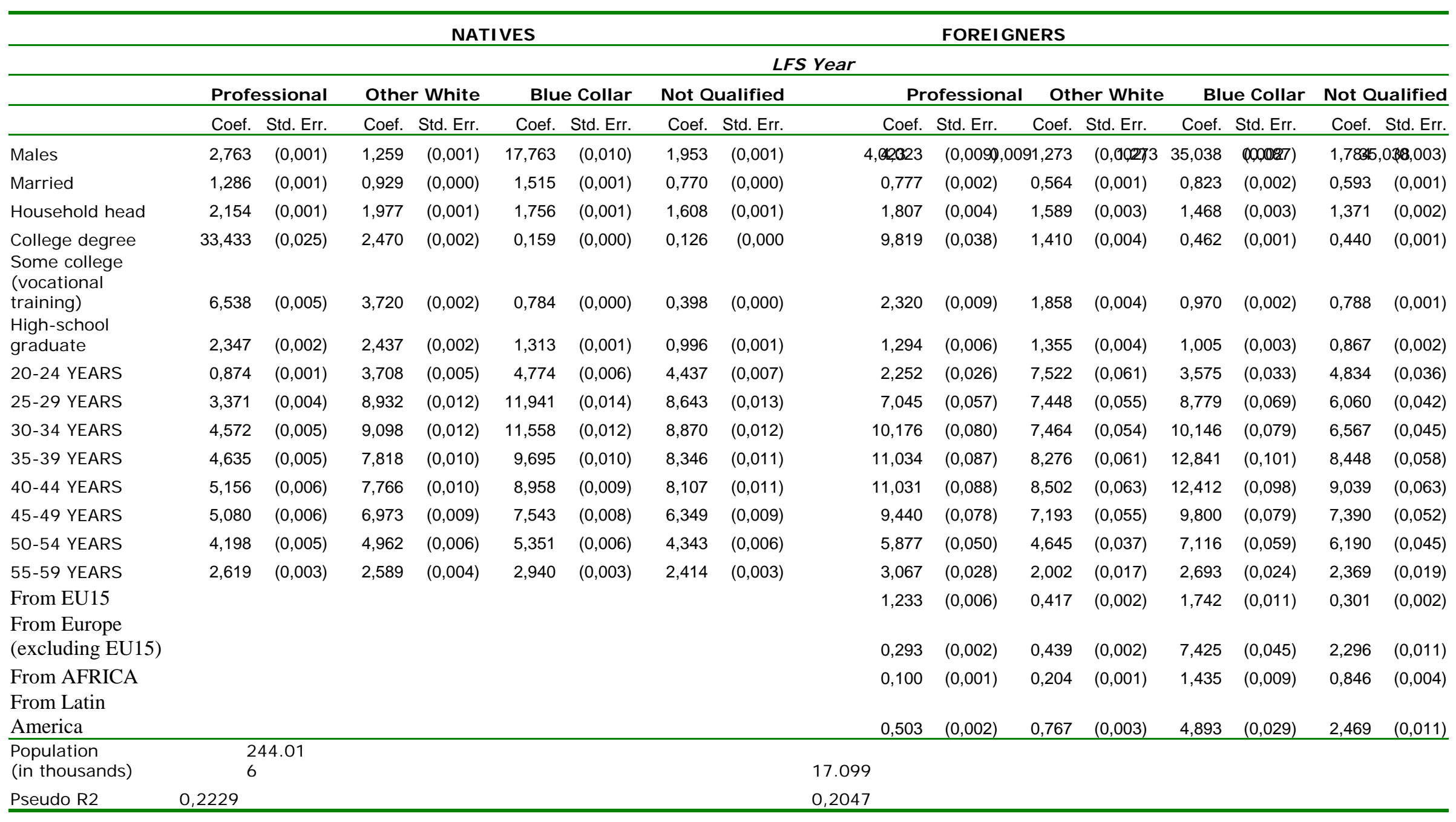


Table A.5. Multinomial Logit, Relative Risk Ratios, LFS 2000-2008 (Continued)

\begin{tabular}{|c|c|c|c|c|c|c|c|c|}
\hline & \multicolumn{3}{|r|}{ NATI VES } & \multicolumn{5}{|c|}{ FOREI GNERS } \\
\hline & \multicolumn{8}{|c|}{ LFS Year } \\
\hline & Professional & Other White & Blue Collar & $\begin{array}{r}\text { Not } \\
\text { Qualified }\end{array}$ & Professional & Other White & Blue Collar & $\begin{array}{r}\text { Not } \\
\text { Qualified } \\
\end{array}$ \\
\hline ANDALUCIA & $1,084(0,005)$ & $0,723(0,003)$ & $2,365(0,014)$ & $1,741(0,010)$ & $0,673(0,025)$ & $1,708(0,057)$ & $1,238(0,038)$ & $5,528(0,172)$ \\
\hline ARAGON & $2,056(0,009)$ & $1,117(0,004)$ & $7,325(0,043)$ & $2,213(0,013)$ & $0,500(0,019)$ & $2,020(0,068)$ & $2,514(0,077)$ & $7,879(0,247)$ \\
\hline ASTURIAS & $1,061(0,005)$ & $0,724(0,003)$ & $3,750(0,022)$ & $1,450(0,009)$ & $1,312(0,052)$ & $2,557(0,088)$ & $2,501(0,081)$ & $5,175(0,168)$ \\
\hline BALEARES & $2,746(0,013)$ & $2,251(0,009)$ & $5,431 \quad(0,032)$ & $2,666(0,016)$ & $1,006(0,038)$ & $2,744(0,091)$ & $3,350(0,103)$ & $6,899(0,216)$ \\
\hline CANARIAS & $1,253(0,006)$ & $1,176(0,005)$ & $2,810(0,016)$ & $2,216(0,013)$ & $0,566(0,021)$ & $2,553(0,085)$ & $1,674(0,051)$ & $4,697(0,147)$ \\
\hline CANTABRIA & $1,246(0,006)$ & $0,923(0,004)$ & $5,118(0,031)$ & $1,976(0,012)$ & $0,382(0,016)$ & $2,501(0,087)$ & $2,259(0,074)$ & $5,338(0,174)$ \\
\hline LEON & $1,351(0,006)$ & $0,929(0,004)$ & $5,394(0,031)$ & $1,873(0,011)$ & $0,347(0,013)$ & $1,489(0,050)$ & $2,530(0,078)$ & $5,312(0,166)$ \\
\hline MANCHA & $1,563(0,007)$ & $0,963(0,004)$ & $5,020(0,029)$ & $1,700(0,010)$ & $0,430(0,016)$ & $1,622(0,054)$ & $2,123(0,065)$ & $5,744(0,180)$ \\
\hline CAT & $2,465(0,011)$ & $1,722(0,006)$ & $6,968(0,040)$ & $2,323(0,014)$ & $0,837(0,031)$ & $2,359(0,078)$ & $2,563(0,078)$ & $5,207(0,162)$ \\
\hline VAL & $1,791(0,008)$ & $1,081(0,004)$ & $5,313(0,031)$ & $2,199(0,013)$ & $0,516(0,019)$ & $1,826(0,061)$ & $1,987(0,061)$ & $4,817(0,150)$ \\
\hline EXT & $1,198(0,005)$ & $0,696(0,003)$ & $2,723(0,016)$ & $1,834(0,011)$ & $0,869(0,035)$ & $1,159(0,042)$ & $0,944(0,032)$ & $6,088(0,198)$ \\
\hline GAL & $1,544(0,007)$ & $0,957(0,004)$ & $6,102(0,035)$ & $1,733(0,010)$ & $0,886(0,034)$ & $1,309(0,044)$ & $1,689(0,053)$ & $3,007(0,095)$ \\
\hline MAD & $2,007(0,009)$ & $1,441(0,005)$ & $3,872(0,022)$ & $2,201(0,013)$ & $0,950(0,036)$ & $2,747(0,091)$ & $2,930(0,089)$ & $7,137(0,222)$ \\
\hline MURCIA & $1,555(0,007)$ & $0,974(0,004)$ & $4,521(0,026)$ & $2,231(0,013)$ & $0,396(0,015)$ & $1,627(0,054)$ & $1,767(0,054)$ & $11,581(0,361)$ \\
\hline NAV & $1,994(0,009)$ & $1,088(0,005)$ & $9,715(0,058)$ & $1,988(0,013)$ & $0,479(0,019)$ & $1,926(0,065)$ & $2,779(0,087)$ & $6,377(0,202)$ \\
\hline PV & $1,721(0,008)$ & $1,010(0,004)$ & $6,389(0,037)$ & $2,129(0,013)$ & $0,613(0,023)$ & $1,875(0,063)$ & $1,833(0,057)$ & $5,274(0,166)$ \\
\hline RIOJA & $1,823(0,009)$ & $1,145(0,005)$ & $8,650(0,054)$ & $1,574(0,011)$ & $0,531(0,021)$ & $1,333(0,046)$ & $3,435(0,108)$ & $6,940(0,221)$ \\
\hline CEUTA & $0,940(0,009)$ & $0,739(0,006)$ & $0,684(0,009)$ & $1,070(0,012)$ & $2,407(0,123)$ & $1,955(0,092)$ & $0,448(0,026)$ & $1,357(0,066)$ \\
\hline $\begin{array}{l}\text { Number of } \\
\text { observations } \\
\text { Population } \\
\text { (in thousands) }\end{array}$ & 244.016 & & & & 17.099 & & & \\
\hline Pseudo R2 & 0,2229 & & & & 0,2047 & & & \\
\hline
\end{tabular}


Table A.5. Multinomial Logit, Relative Risk Ratios, LFS 2000-2008 (Continued)

\begin{tabular}{|c|c|c|c|c|c|c|c|c|}
\hline & \multicolumn{4}{|c|}{ NATI VES } & \multicolumn{4}{|c|}{ FOREIGNERS } \\
\hline & \multicolumn{8}{|c|}{ Occupation } \\
\hline & Professional & Other White & Blue Collar & $\begin{array}{r}\text { Not } \\
\text { Qualified } \\
\end{array}$ & Professional & Other White & Blue Collar & $\begin{array}{r}\text { Not } \\
\text { Qualified } \\
\end{array}$ \\
\hline EPA01 & $1,054(0,001)$ & $1,027(0,001)$ & $1,069(0,001)$ & $1,025(0,001)$ & $1,141(0,008)$ & $1,035(0,006)$ & $1,376(0,010)$ & $1,404(0,008)$ \\
\hline EPA02 & $1,064(0,001)$ & $1,049(0,001)$ & $1,085(0,001)$ & $1,066(0,001)$ & $0,825(0,006)$ & $1,120(0,006)$ & $1,283(0,008)$ & $1,277(0,007)$ \\
\hline EPA03 & $1,103(0,001)$ & $1,105(0,001)$ & $1,138(0,001)$ & $1,121(0,001)$ & $0,756(0,005)$ & $0,841(0,005)$ & $1,216(0,008)$ & $1,255(0,006)$ \\
\hline EPA04 & $1,157(0,001)$ & $1,123(0,001)$ & $1,184(0,001)$ & $1,158(0,001)$ & $0,915(0,006)$ & $0,757(0,004)$ & $1,267(0,008)$ & $1,216(0,006)$ \\
\hline EPA05 & $1,187(0,001)$ & $1,224(0,001)$ & $1,289(0,001)$ & $1,246(0,001)$ & $0,999(0,006)$ & $1,070(0,006)$ & $1,415(0,009)$ & $1,426(0,007)$ \\
\hline EPA06 & $1,267(0,001)$ & $1,293(0,001)$ & $1,352(0,001)$ & $1,305(0,001)$ & $0,926(0,006)$ & $1,130(0,006)$ & $1,554(0,009)$ & $1,431(0,007)$ \\
\hline EPA07 & $1,409(0,001)$ & $1,360(0,001)$ & $1,430(0,001)$ & $1,361(0,002)$ & $0,802(0,005)$ & $1,026(0,005)$ & $1,438(0,008)$ & $1,329(0,006)$ \\
\hline EPA08 & $1,370(0,001)$ & $1,342(0,001)$ & $1,355(0,001)$ & $1,280(0,001)$ & $0,781(0,005)$ & $0,931(0,005)$ & $1,334(0,008)$ & $1,022(0,005)$ \\
\hline Year since arrival, 1 & & & & & $0,655(0,003)$ & $1,080(0,003)$ & $0,928(0,003)$ & $1,259(0,003)$ \\
\hline Years since arrival, 2 & & & & & $0,610(0,002)$ & $1,596(0,005)$ & $1,253(0,004)$ & $1,614(0,004)$ \\
\hline Years since arrival, 3 & & & & & $0,754(0,003)$ & $1,877(0,006)$ & $1,776(0,006)$ & $1,736(0,005)$ \\
\hline Years since arrival, 4 & & & & & $0,876(0,003)$ & $1,982(0,006)$ & $1,656(0,005)$ & $1,668(0,005)$ \\
\hline Years since arrival, 5 & & & & & $0,986(0,004)$ & $2,092(0,007)$ & $2,301(0,007)$ & $1,810(0,005)$ \\
\hline Years since arrival, 6 & & & & & $0,973(0,004)$ & $1,842(0,006)$ & $1,896(0,006)$ & $1,557(0,005)$ \\
\hline Years since arrival, 7 & & & & & $0,996(0,005)$ & $1,671(0,007)$ & $1,677(0,007)$ & $1,379(0,005)$ \\
\hline Years since arrival, 8 & & & & & $0,793(0,004)$ & $1,774(0,008)$ & $1,730(0,008)$ & $1,266(0,005)$ \\
\hline Years since arrival, 9 & & & & & $1,372(0,009)$ & $1,498(0,009)$ & $1,449(0,009)$ & $1,442(0,007)$ \\
\hline \multicolumn{9}{|l|}{$\begin{array}{l}\text { Number of } \\
\text { observations }\end{array}$} \\
\hline (in thousands) & 244.016 & & & & 17.099 & & & \\
\hline Pseudo R2 & 0,2229 & & & & 0,2047 & & & \\
\hline
\end{tabular}


Table A.6

Occupational Distribution Fitted Probabilities for Native Males, by LFS

\begin{tabular}{|c|c|c|c|c|c|}
\hline & Professional & Other White & Blue Collar & Non Qualified & Not Working \\
\hline \multicolumn{6}{|c|}{ High-school dropouts } \\
\hline$E P A=2000$ & 0,08 & 0,09 & 0,52 & 0,15 & 0,16 \\
\hline $\mathrm{EPA}=2001$ & 0,08 & 0,09 & 0,53 & 0,14 & 0,15 \\
\hline $\mathrm{EPA}=2002$ & 0,08 & 0,09 & 0,53 & 0,15 & 0,15 \\
\hline$E P A=2003$ & 0,08 & 0,09 & 0,54 & 0,15 & 0,14 \\
\hline$E P A=2004$ & 0,08 & 0,09 & 0,54 & 0,15 & 0,14 \\
\hline $\mathrm{EPA}=2005$ & 0,08 & 0,09 & 0,55 & 0,15 & 0,13 \\
\hline $\mathrm{EPA}=2006$ & 0,08 & 0,10 & 0,55 & 0,15 & 0,12 \\
\hline $\mathrm{EPA}=2007$ & 0,08 & 0,10 & 0,56 & 0,15 & 0,12 \\
\hline$E P A=2008$ & 0,08 & 0,10 & 0,55 & 0,15 & 0,12 \\
\hline \multicolumn{6}{|c|}{ High-school graduates } \\
\hline$E P A=2000$ & 0,13 & 0,16 & 0,49 & 0,10 & 0,11 \\
\hline $\mathrm{EPA}=2001$ & 0,13 & 0,16 & 0,50 & 0,10 & 0,11 \\
\hline $\mathrm{EPA}=2002$ & 0,13 & 0,16 & 0,50 & 0,10 & 0,11 \\
\hline$E P A=2003$ & 0,13 & 0,16 & 0,50 & 0,11 & 0,10 \\
\hline$E P A=2004$ & 0,13 & 0,16 & 0,50 & 0,11 & 0,10 \\
\hline$E P A=2005$ & 0,13 & 0,16 & 0,51 & 0,11 & 0,09 \\
\hline$E P A=2006$ & 0,13 & 0,16 & 0,51 & 0,11 & 0,09 \\
\hline $\mathrm{EPA}=2007$ & 0,14 & 0,16 & 0,51 & 0,10 & 0,08 \\
\hline$E P A=2008$ & 0,14 & 0,17 & 0,51 & 0,10 & 0,09 \\
\hline \multicolumn{6}{|c|}{ With vocational training } \\
\hline $\mathrm{EPA}=2000$ & 0,35 & 0,24 & 0,27 & 0,04 & 0,11 \\
\hline $\mathrm{EPA}=2001$ & 0,35 & 0,23 & 0,28 & 0,04 & 0,10 \\
\hline $\mathrm{EPA}=2002$ & 0,35 & 0,23 & 0,28 & 0,04 & 0,10 \\
\hline $\mathrm{EPA}=2003$ & 0,35 & 0,24 & 0,28 & 0,04 & 0,10 \\
\hline$E P A=2004$ & 0,35 & 0,23 & 0,28 & 0,04 & 0,09 \\
\hline$E P A=2005$ & 0,34 & 0,24 & 0,29 & 0,04 & 0,09 \\
\hline$E P A=2006$ & 0,34 & 0,24 & 0,29 & 0,04 & 0,08 \\
\hline $\mathrm{EPA}=2007$ & 0,36 & 0,24 & 0,29 & 0,04 & 0,08 \\
\hline $\mathrm{EPA}=2008$ & 0,36 & 0,24 & 0,28 & 0,04 & 0,08 \\
\hline \multicolumn{6}{|c|}{ College graduates } \\
\hline$E P A=2000$ & 0,84 & 0,07 & 0,03 & 0,01 & 0,05 \\
\hline$E P A=2001$ & 0,85 & 0,07 & 0,03 & 0,01 & 0,05 \\
\hline $\mathrm{EPA}=2002$ & 0,85 & 0,07 & 0,03 & 0,01 & 0,05 \\
\hline $\mathrm{EPA}=2003$ & 0,85 & 0,08 & 0,03 & 0,01 & 0,05 \\
\hline$E P A=2004$ & 0,85 & 0,07 & 0,03 & 0,01 & 0,04 \\
\hline$E P A=2005$ & 0,85 & 0,08 & 0,03 & 0,01 & 0,04 \\
\hline$E P A=2006$ & 0,85 & 0,08 & 0,03 & 0,01 & 0,04 \\
\hline $\mathrm{EPA}=2007$ & 0,86 & 0,07 & 0,03 & 0,01 & 0,04 \\
\hline $\mathrm{EPA}=2008$ & 0,86 & 0,07 & 0,03 & 0,01 & 0,04 \\
\hline
\end{tabular}


Table A.7

Occupational Distribution Fitted Probabilities for Native Females, by LFS

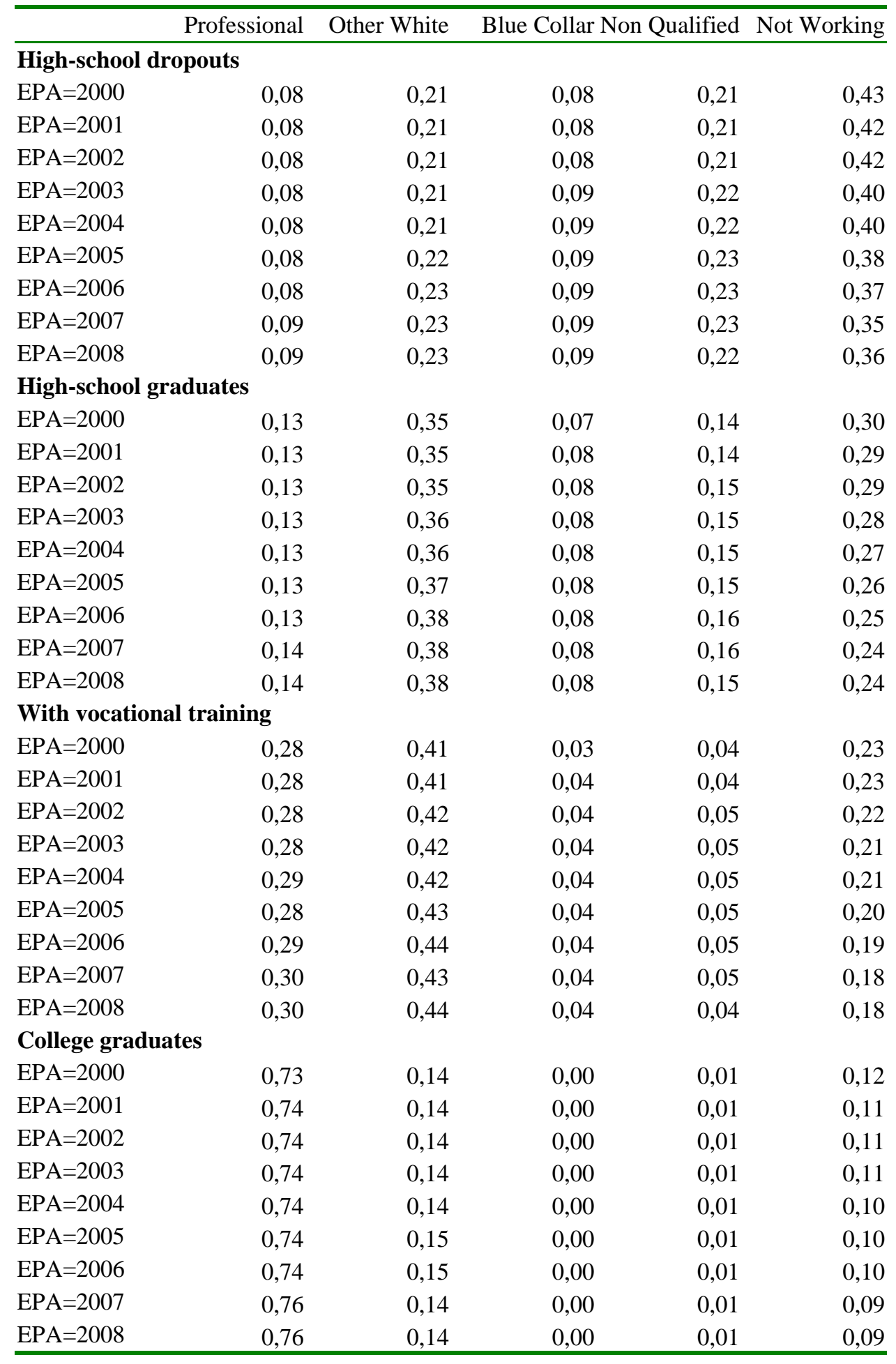


Table A.8. Probability of Working with a Permanent Contract, Wage and Salary Male Workers, 2000-2008 LFS

\begin{tabular}{|c|c|c|c|}
\hline & $\begin{array}{c}\text { High-school } \\
\text { dropout }\end{array}$ & $\begin{array}{c}\text { High-school } \\
\text { graduate }\end{array}$ & $\begin{array}{c}\text { University } \\
\text { degree }\end{array}$ \\
\hline immigrant & $\begin{array}{c}-0.439 * * * \\
(0.0295)\end{array}$ & $\begin{array}{c}-0.455^{* * * *} \\
(0.0198)\end{array}$ & $\begin{array}{c}-0.345^{* * *} \\
(0.0414)\end{array}$ \\
\hline YSA & $\begin{array}{c}0.00927 * * \\
(0.00408)\end{array}$ & $\begin{array}{c}0.00410^{*} \\
(0.00222)\end{array}$ & $\begin{array}{c}0.00183 \\
(0.00279)\end{array}$ \\
\hline sqr_YSA & $\begin{array}{c}-0.000246 * * \\
(9.85 \mathrm{e}-05)\end{array}$ & $\begin{array}{c}-0.000139 * * \\
(6.17 \mathrm{e}-05)\end{array}$ & $\begin{array}{c}-7.17 \mathrm{e}-05 \\
(6.60 \mathrm{e}-05)\end{array}$ \\
\hline arr_cohort_89 & $\begin{array}{c}0.114 \\
(0.0962)\end{array}$ & $\begin{array}{c}0.0779 \\
(0.0739)\end{array}$ & \\
\hline arr_cohort_90_94 & $\begin{array}{c}0.122 \\
(0.0761)\end{array}$ & $\begin{array}{c}0.0842 \\
(0.0558)\end{array}$ & $\begin{array}{l}0.0775^{*} \\
(0.0463)\end{array}$ \\
\hline arr_cohort_95_99 & $\begin{array}{c}0.0945^{* *} \\
(0.0393)\end{array}$ & $\begin{array}{c}0.0939 * * * \\
(0.0203)\end{array}$ & $\begin{array}{c}0.0745 \\
(0.0612)\end{array}$ \\
\hline arr_cohort_00_04 & $\begin{array}{c}0.0864 * * * \\
(0.0327)\end{array}$ & $\begin{array}{c}0.0733 * * * \\
(0.0212)\end{array}$ & $\begin{array}{c}0.0163 \\
(0.0260)\end{array}$ \\
\hline age20 & $\begin{array}{c}-0.176 * * * \\
(0.0130)\end{array}$ & $\begin{array}{l}-0.271^{* * *} \\
(0.00795)\end{array}$ & $\begin{array}{c}-0.446^{* * *} \\
(0.0200)\end{array}$ \\
\hline age25 & $\begin{array}{c}-0.0673 * * * \\
(0.0120)\end{array}$ & $\begin{array}{c}-0.116 * * * \\
(0.00689)\end{array}$ & $\begin{array}{c}-0.194 * * * \\
(0.0119)\end{array}$ \\
\hline age30 & $\begin{array}{c}-0.0310 * * * \\
(0.00955)\end{array}$ & $\begin{array}{c}-0.0421^{* * *} \\
(0.00506)\end{array}$ & $\begin{array}{c}-0.0390 * * * \\
(0.00710)\end{array}$ \\
\hline age40 & $\begin{array}{c}0.0335 * * * \\
(0.00829)\end{array}$ & $\begin{array}{c}0.0413 * * * \\
(0.00480)\end{array}$ & $\begin{array}{c}0.0517 * * * \\
(0.00620)\end{array}$ \\
\hline age45 & $\begin{array}{l}0.0862 * * * \\
(0.00806)\end{array}$ & $\begin{array}{c}0.0762 * * * \\
(0.00521)\end{array}$ & $\begin{array}{c}0.0813 * * * \\
(0.00607)\end{array}$ \\
\hline age50 & $\begin{array}{l}0.116 * * * \\
(0.00798)\end{array}$ & $\begin{array}{l}0.107 * * * \\
(0.00565)\end{array}$ & $\begin{array}{l}0.111^{* * *} \\
(0.00516)\end{array}$ \\
\hline age55 & $\begin{array}{l}0.149 * * * \\
(0.00762)\end{array}$ & $\begin{array}{l}0.134 * * * \\
(0.00594)\end{array}$ & $\begin{array}{l}0.121^{* * *} \\
(0.00502)\end{array}$ \\
\hline age60 & $\begin{array}{c}0.183^{* * *} \\
(0.00776)\end{array}$ & $\begin{array}{c}0.159 * * * \\
(0.00778)\end{array}$ & $\begin{array}{c}0.117 * * * \\
(0.00542)\end{array}$ \\
\hline LFS01 & $\begin{array}{c}-0.0266 * * * \\
(0.00867)\end{array}$ & $\begin{array}{c}-0.0490 * * * \\
(0.00902)\end{array}$ & $\begin{array}{l}0.0210 * * \\
(0.00888)\end{array}$ \\
\hline LFS02 & $\begin{array}{c}-0.0259 * * * \\
(0.00887)\end{array}$ & $\begin{array}{c}-0.0396 * * * \\
(0.00880)\end{array}$ & $\begin{array}{c}0.0263 * * * \\
(0.00837)\end{array}$ \\
\hline LFS03 & $\begin{array}{l}-0.0175^{*} \\
(0.00895)\end{array}$ & $\begin{array}{c}-0.0323 * * * \\
(0.00864)\end{array}$ & $\begin{array}{l}0.0195^{* *} \\
(0.00842)\end{array}$ \\
\hline LFS04 & $\begin{array}{c}-0.0144 \\
(0.00930)\end{array}$ & $\begin{array}{c}-0.0269 * * * \\
(0.00852)\end{array}$ & $\begin{array}{c}0.0148^{*} \\
(0.00873)\end{array}$ \\
\hline LFS05 & $\begin{array}{c}-0.0300 * * * \\
(0.0106)\end{array}$ & $\begin{array}{c}-0.0447 * * * \\
(0.00931)\end{array}$ & $\begin{array}{c}0.00235 \\
(0.00975)\end{array}$ \\
\hline LFS06 & $\begin{array}{c}-0.0246^{* *} \\
(0.0110)\end{array}$ & $\begin{array}{c}-0.0472 * * * \\
(0.00925)\end{array}$ & $\begin{array}{c}0.00306 \\
(0.00988)\end{array}$ \\
\hline LFS07 & $\begin{array}{l}-0.0209 * \\
(0.0114)\end{array}$ & $\begin{array}{l}-0.0208 * * \\
(0.00921)\end{array}$ & $\begin{array}{l}0.0196 * * \\
(0.00948)\end{array}$ \\
\hline LFS08 & $\begin{array}{c}0.0221 * * \\
(0.0101)\end{array}$ & $\begin{array}{c}0.00719 \\
(0.00838)\end{array}$ & $\begin{array}{c}0.0240 * * * \\
(0.00853)\end{array}$ \\
\hline married & $\begin{array}{l}0.113^{* * *} \\
(0.00657)\end{array}$ & $\begin{array}{l}0.104 * * * \\
(0.00423)\end{array}$ & $\begin{array}{c}0.0927 * * * \\
(0.00615)\end{array}$ \\
\hline Province UR & $\begin{array}{c}-0.000172 \\
(0.000704)\end{array}$ & $\begin{array}{c}-0.00181 * * * \\
(0.000497)\end{array}$ & $\begin{array}{c}-8.47 e-05 \\
(0.000654)\end{array}$ \\
\hline Observations & 89,670 & 180,324 & 60,848 \\
\hline
\end{tabular}

Note: Marginal effects. Robust standard errors in parentheses. Regressions include region dummies. In all cases, we use sampling weights. ${ }^{* * *} \mathrm{p}<0.01,{ }^{* *} \mathrm{p}<0.05$, ${ }^{*} \mathrm{p}<0.1$ 
Table A.9. Probability of Working with a Permanent Contract, Wage and Salary Female Workers, 2000-2008 LFS

\begin{tabular}{|c|c|c|c|}
\hline & $\begin{array}{c}\text { High-school } \\
\text { dropout }\end{array}$ & $\begin{array}{l}\text { High-school } \\
\text { graduate }\end{array}$ & $\begin{array}{c}\text { University } \\
\text { degree }\end{array}$ \\
\hline \multirow[t]{2}{*}{ immigrant } & $-0.228 * * *$ & $-0.304 * * *$ & $-0.253^{* * *}$ \\
\hline & $(0.0470)$ & $(0.0200)$ & $(0.0385)$ \\
\hline \multirow[t]{2}{*}{ YSA } & $0.00900 *$ & $0.00447^{*}$ & $-0.00602 *$ \\
\hline & $(0.00488)$ & $(0.00253)$ & $(0.00361)$ \\
\hline \multirow[t]{2}{*}{ sqr_YSA } & -0.000193 & -0.000108 & 0.000160 \\
\hline & $(0.000117)$ & $(7.05 \mathrm{e}-05)$ & $(0.000103)$ \\
\hline \multirow[t]{2}{*}{ arr_cohort_89 } & $0.322 * * *$ & 0.107 & \\
\hline & $(0.0379)$ & $(0.112)$ & \\
\hline \multirow[t]{2}{*}{ arr_cohort_90_94 } & $0.285^{* * *}$ & -0.0103 & -0.154 \\
\hline & $(0.0528)$ & $(0.0892)$ & $(0.164)$ \\
\hline \multirow[t]{2}{*}{ arr_cohort_95_99 } & 0.0702 & $0.0566 * *$ & -0.0777 \\
\hline & $(0.0533)$ & $(0.0273)$ & $(0.192)$ \\
\hline \multirow[t]{2}{*}{ arr_cohort_00_04 } & 0.0291 & $0.0350 *$ & -0.0249 \\
\hline & $(0.0597)$ & $(0.0206)$ & $(0.0549)$ \\
\hline \multirow[t]{2}{*}{ age20 } & $-0.197 * * *$ & $-0.241 * * *$ & $-0.444 * * *$ \\
\hline & $(0.0177)$ & $(0.00870)$ & $(0.0138)$ \\
\hline \multirow[t]{2}{*}{ age25 } & $-0.0900 * * *$ & $-0.0784^{* * *}$ & $-0.228 * * *$ \\
\hline & $(0.0168)$ & $(0.00783)$ & $(0.0107)$ \\
\hline \multirow[t]{2}{*}{ age30 } & $-0.0444 * * *$ & $-0.0250 * * *$ & $-0.0633 * * *$ \\
\hline & $(0.0144)$ & $(0.00647)$ & $(0.00786)$ \\
\hline \multirow[t]{2}{*}{ age40 } & $0.0319 * * *$ & $0.0449 * * *$ & $0.0698 * * *$ \\
\hline & $(0.0118)$ & $(0.00626)$ & $(0.00767)$ \\
\hline \multirow[t]{2}{*}{ age45 } & $0.0624 * * *$ & $0.0798 * * *$ & $0.142 * * *$ \\
\hline & $(0.0120)$ & $(0.00695)$ & (0.00733) \\
\hline \multirow[t]{2}{*}{ age50 } & $0.111^{* * *}$ & $0.108 * * *$ & $0.176 * * *$ \\
\hline & $(0.0119)$ & $(0.00796)$ & $(0.00737)$ \\
\hline \multirow[t]{2}{*}{ age55 } & $0.136^{* * *}$ & $0.144 * * *$ & $0.214^{* * *}$ \\
\hline & $(0.0116)$ & $(0.00911)$ & $(0.00657)$ \\
\hline \multirow[t]{2}{*}{ age60 } & $0.150 * * *$ & $0.166 * * *$ & $0.197 * * *$ \\
\hline & $(0.0128)$ & $(0.0139)$ & $(0.0109)$ \\
\hline \multirow[t]{2}{*}{ LFS00 } & -0.00907 & $-0.0257 * *$ & 0.00318 \\
\hline & $(0.0116)$ & $(0.0111)$ & (0.0109) \\
\hline \multirow[t]{2}{*}{ LFS01 } & -0.00268 & $-0.0261 * *$ & 0.0144 \\
\hline & $(0.0135)$ & $(0.0116)$ & $(0.0114)$ \\
\hline \multirow[t]{2}{*}{ LFS02 } & -0.0142 & $-0.0323 * * *$ & 0.0111 \\
\hline & $(0.0130)$ & $(0.0116)$ & $(0.0112)$ \\
\hline \multirow[t]{2}{*}{ LFS03 } & -0.00669 & $-0.0208^{*}$ & -0.00170 \\
\hline & $(0.0131)$ & $(0.0113)$ & $(0.0111)$ \\
\hline \multirow[t]{2}{*}{ LFS04 } & -0.0174 & $-0.0303^{* * *}$ & 0.00471 \\
\hline & $(0.0134)$ & (0.0113) & $(0.0110)$ \\
\hline LFS05 & -0.0212 & $-0.0242 * *$ & -0.0198 \\
\hline & $(0.0152)$ & $(0.0118)$ & $(0.0121)$ \\
\hline LFS06 & $-0.0647 * * *$ & $-0.0380 * * *$ & -0.0182 \\
\hline & (0.0154) & (0.0119) & $(0.0121)$ \\
\hline LFS07 & 0.000892 & 0.00265 & 0.00115 \\
\hline & $(0.0152)$ & $(0.0116)$ & $(0.0121)$ \\
\hline LFS08 & $0.0389 * * *$ & $0.0197^{*}$ & -0.00168 \\
\hline & $(0.0140)$ & $(0.0109)$ & $(0.0112)$ \\
\hline married & -0.00903 & $0.0478 * * *$ & $0.0700 * * *$ \\
\hline & $(0.00713)$ & $(0.00434)$ & $(0.00581)$ \\
\hline tparo_prov & $0.00432 * * *$ & $0.00164 * *$ & 0.000968 \\
\hline & $(0.00105)$ & $(0.000662)$ & (0.000787) \\
\hline Observations & 42,986 & 121,363 & 72,077 \\
\hline
\end{tabular}

Note: Marginal effects. Robust standard errors in parentheses. Regressions include region dummies. In all cases, we use sampling weights. ${ }^{* * *} \mathrm{p}<0.01,{ }^{* *} \mathrm{p}<0.05,{ }^{*} \mathrm{p}<0.1$ 
Table A.10

Wage Equation Estimations at Percentile 50

Longitudinal 1979-2005 CSWH

\begin{tabular}{|c|c|c|c|}
\hline & High-school dropouts & High-school graduates & University degree \\
\hline \multirow[t]{2}{*}{ Birth cohort $<=1934$} & $-0,0819$ & $-0,0347$ & $-0,2123$ \\
\hline & $(0,0086)$ & $(0,0271)$ & $(0,013)$ \\
\hline \multirow[t]{2}{*}{ Birth cohort 1935-1944 } & 0,0909 & $-0,0039$ & $-0,1372$ \\
\hline & $(0,0025)$ & $(0,0081)$ & $(0,0048)$ \\
\hline \multirow[t]{2}{*}{ Birth cohort 1945-1954 } & 0,3041 & 0,0591 & $-0,0919$ \\
\hline & $(0,0012)$ & $(0,0041)$ & $(0,0026)$ \\
\hline \multirow[t]{2}{*}{ Birth cohort 1955-1964 } & 0,2707 & $\mathbf{0 , 0 9 3 7}$ & $-0,0417$ \\
\hline & $(0,001)$ & $(0,0025)$ & $(0,0016)$ \\
\hline \multirow[t]{2}{*}{ Birth cohort 1965-1974 } & 0,1574 & 0,0317 & $-0,0206$ \\
\hline & $(0,0009)$ & $(0,0022)$ & $(0,0013)$ \\
\hline \multirow[t]{2}{*}{ nairu } & $-0,0489$ & $-0,029$ & $-0,0224$ \\
\hline & $(0,0002)$ & $(0,0005)$ & $(0,0004)$ \\
\hline \multirow[t]{2}{*}{ Total experience } & $\mathbf{0 , 1 3 0 1}$ & 0,0876 & 0,0459 \\
\hline & $(0,0007)$ & $(0,0024)$ & $(0,0015)$ \\
\hline \multirow[t]{2}{*}{ (Total experience) $)^{2} / 10$} & $-0,0137$ & $-0,009$ & $-0,0041$ \\
\hline & $(0,0001)$ & $(0,0003)$ & $(0,0002)$ \\
\hline \multirow[t]{2}{*}{ (Total experience) $)^{3} / 100$} & 0,0007 & 0,0005 & 0,0002 \\
\hline & $(0,000)$ & $(0,000)$ & $(0,000)$ \\
\hline \multirow[t]{2}{*}{ (Total experience) $)^{4} / 1000$} & $\mathbf{0 , 0 0 0}$ & $\mathbf{0 , 0 0 0}$ & $\mathbf{0 , 0 0 0}$ \\
\hline & $(0,000)$ & $(0,000)$ & $(0,000)$ \\
\hline \multirow[t]{2}{*}{ No-UE15 } & 0,356 & $-0,420$ & $-0,283$ \\
\hline & $(0,0231)$ & $(0,0634)$ & $(0,0322)$ \\
\hline \multirow[t]{2}{*}{ Years since migration, 1-2 } & 0,1008 & 0,1021 & 0,0331 \\
\hline & $(0,0092)$ & $(0,0153)$ & $(0,0046)$ \\
\hline \multirow[t]{2}{*}{ Years since migration, 3-4 } & 0,1132 & 0,1102 & 0,0434 \\
\hline & $(0,0101)$ & $(0,0169)$ & $(0,0052)$ \\
\hline \multirow[t]{2}{*}{ Years since migration, 5-6 } & $\mathbf{0 , 0 7 1 7}$ & 0,0939 & 0,0322 \\
\hline & $(0,0129)$ & $(0,0234)$ & $(0,0079)$ \\
\hline \multirow[t]{2}{*}{ Years since migration, 7-8 } & 0,0489 & 0,0908 & 0,0339 \\
\hline & $(0,0149)$ & $(0,0293)$ & $(0,0106)$ \\
\hline \multirow[t]{2}{*}{ Years since migration, 9-10 } & 0,0738 & 0,1116 & 0,0417 \\
\hline & $(0,0169)$ & $(0,0334)$ & $(0,0131)$ \\
\hline \multirow[t]{2}{*}{ Years since migration, 11-12 } & $\mathbf{0 , 1 3 2 7}$ & 0,0878 & 0,0467 \\
\hline & $(0,0185)$ & $(0,0385)$ & $(0,0152)$ \\
\hline \multirow[t]{2}{*}{ More than 13 years since migration } & 0,1912 & 0,0841 & 0,0411 \\
\hline & $(0,0195)$ & $(0,0414)$ & $(0,0177)$ \\
\hline \multirow[t]{2}{*}{ exp_abroad 5 to 9 years } & $-0,2283$ & $-0,1224$ & $-0,1009$ \\
\hline & $(0,0085)$ & $(0,0156)$ & $(0,0055)$ \\
\hline \multirow[t]{2}{*}{ exp_abroad 10 to 14 years } & $-0,3746$ & $-0,1326$ & $-0,1399$ \\
\hline & $(0,0081)$ & $(0,0147)$ & $(0,0047)$ \\
\hline exp_abroad 15 to 19 years & $-0,4189$ & $-0,2345$ & $-0,1842$ \\
\hline
\end{tabular}




\begin{tabular}{cccc} 
& $(0,0095)$ & $(0,0168)$ & $(0,0054)$ \\
More than 20 years of exp_abroad & $\mathbf{- 0 , 4 6 9 6}$ & $\mathbf{- 0 , 2 5 5}$ & $\mathbf{- 0 , 2 1 2 9}$ \\
& $(0,0143)$ & $(0,0233)$ & $(0,0073)$ \\
Year_arrival_83-85 & $\mathbf{- 0 , 4 0 7 1}$ & $\mathbf{0 , 0 0 0 7}$ & $\mathbf{0 , 0 4 0 3}$ \\
& $(0,0284)$ & $(0,0903)$ & $(0,0504)$ \\
Year_arrival_86-90 & $\mathbf{- 0 , 2 4 0 5}$ & $\mathbf{0 , 2 1 4 9}$ & $\mathbf{0 , 1 3 6 8}$ \\
& $(0,0229)$ & $(0,0663)$ & $(0,035)$ \\
Year_arrival_91-95 & $\mathbf{- 0 , 3 6 1 3}$ & $\mathbf{0 , 1 9 8 1}$ & $\mathbf{0 , 1 9 3 5}$ \\
& $(0,0212)$ & $(0,0611)$ & $(0,0318)$ \\
Year_arrival_96-00 & $\mathbf{- 0 , 4 5 6 9}$ & $\mathbf{0 , 2 2 1 5}$ & $\mathbf{0 , 2 5 5 5}$ \\
& $(0,0216)$ & $(0,0621)$ & $(0,032)$ \\
Year_arrival_01-05 & $\mathbf{- 0 , 4 2 5 4}$ & $\mathbf{0 , 2 4 1 5}$ & $\mathbf{0 , 2 5 2 7}$ \\
& $(0,0219)$ & $(0,0624)$ & $(0,0321)$ \\
Constant & $\mathbf{8 , 7 6 7 2}$ & $\mathbf{8 , 3 1 9 2}$ & $\mathbf{8 , 3 2 4 3}$ \\
& $(0,0026)$ & $(0,0082)$ & $(0,0051)$ \\
\hline N & & & $1,328,518$ \\
$\mathbf{R}^{2}$ & 938,180 & 915,107 & $\mathbf{0 , 0 2 8 5}$ \\
\hline
\end{tabular}

Note: Dependent variable: logarithm of daily wages. Standard errors in parentheses. Regressions are estimated pooling natives and immigrants coming from countries outside the EU-15. In addition, regressions include region dummies. Restricting time effects to certain macroeconomic variables has been widely used in the literature (see Beaudry and Lemieux, 1999). The analysis is done with the same sample as in Izquierdo et al., 2009. 